\title{
\#USGS
}

science for a changing world Prepared in cooperation with the Coastal Protection and Restoration Authority
(CPRA) of Lotisiana

\section{Performance Measures for a Mississippi River Reintroduction Into the forested Wetlands of} Maurepas Swamp

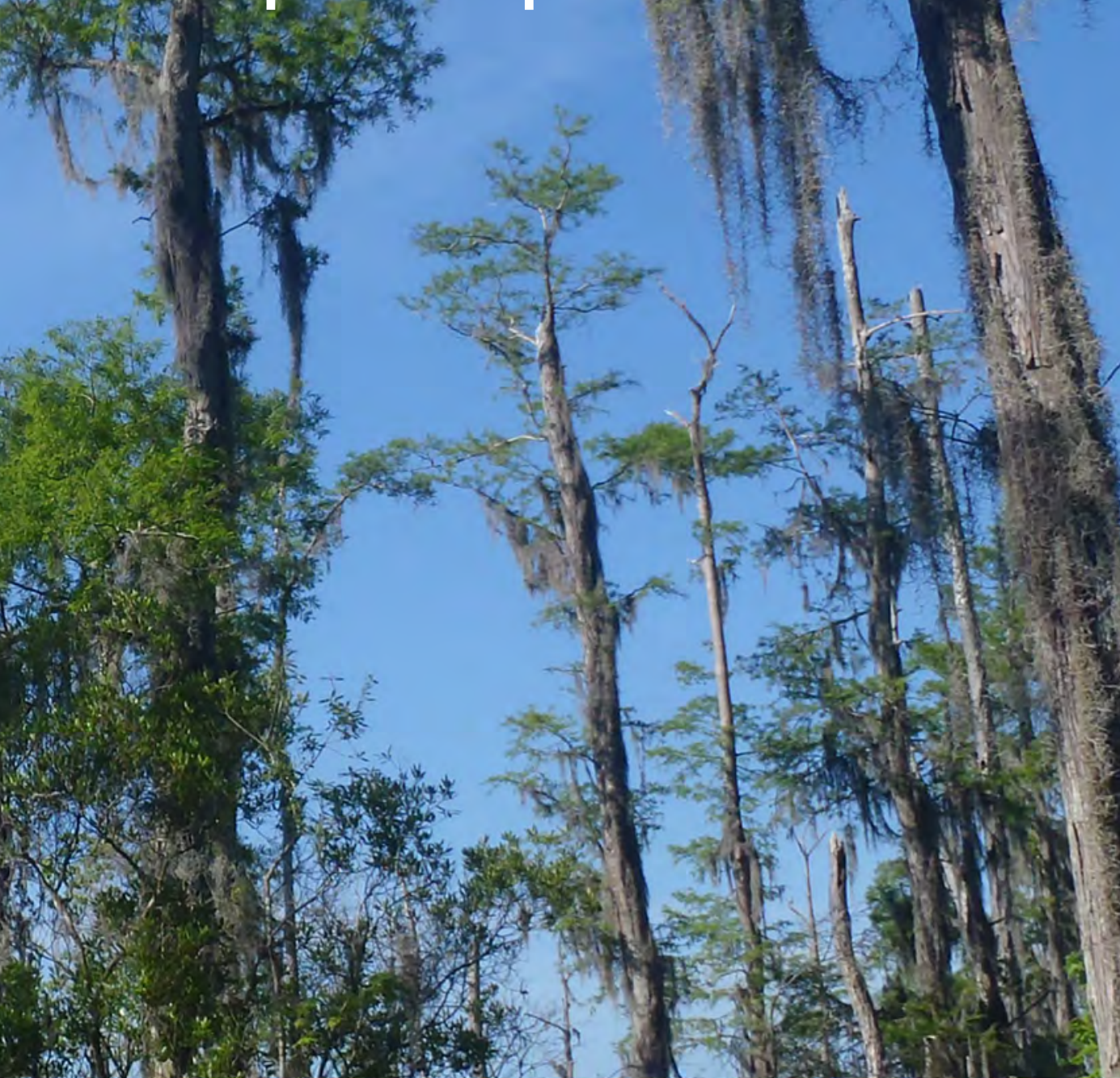

Scientific lavestetgatons hepert $2017-5036$

$$
\text { 1) }
$$

U.S. Department of the Interiof U.S. Geologipal Survey 
Cover. Coastal swamp forest in Louisiana undergoing a transition between a closed canopy and open canopy habitat, representing the primary habitat targeted for a Mississippi River reintroduction into Maurepas Swamp, Louisiana (photograph by Ken W. Krauss, U.S. Geological Survey). 


\section{Performance Measures for a Mississippi River Reintroduction Into the Forested Wetlands of Maurepas Swamp}

By Ken W. Krauss, Gary P. Shaffer, Richard F. Keim, Jim L. Chambers, William B. Wood, and Stephen B. Hartley

Prepared in cooperation with the Coastal Protection and Restoration Authority (CPRA) of Louisiana

Scientific Investigations Report 2017-5036 


\title{
U.S. Department of the Interior \\ RYAN K. ZINKE, Secretary
}

\section{U.S. Geological Survey William H. Werkheiser, Acting Director}

\author{
U.S. Geological Survey, Reston, Virginia: 2017
}

For more information on the USGS - the Federal source for science about the Earth, its natural and living resources, natural hazards, and the environment—visit http://www.usgs.gov or call 1-888-ASK-USGS.

For an overview of USGS information products, including maps, imagery, and publications, visit http://store.usgs.gov.

Any use of trade, firm, or product names is for descriptive purposes only and does not imply endorsement by the U.S. Government.

Although this information product, for the most part, is in the public domain, it also may contain copyrighted materials as noted in the text. Permission to reproduce copyrighted items must be secured from the copyright owner.

Suggested citation:

Krauss, K.W., Shaffer, G.P., Keim, R.F., Chambers, J.L., Wood, W.B., and Hartley, S.B., 2017, Performance measures for a Mississippi River reintroduction into the forested wetlands of Maurepas Swamp: U.S. Geological Survey Scientific Investigations Report 2017-5036, 56 p., https://doi.org/10.3133/sir20175036.

ISSN 2328-0328 (online) 


\section{Acknowledgments}

The development of these performance measures was supported by the Coastal Protection and Restoration Authority (CPRA) of Louisiana. Specifically, we thank Carol Parsons Richards, Honora Buras, Brad Miller, and Richard Raynie, all with CPRA, for tasking this effort and providing much needed feedback along the way. Along with these partners, additional reviews of this document were provided by Danielle Richardi (CPRA), Christopher M. Swarzenski (U.S. Geological Survey [USGS]), William H. Conner (Clemson University), Robert R. Lane (Louisiana State University), Steve Smith (Louisiana Department of Wildlife and Fisheries), and Beth A. Middleton (USGS). Supplemental funding for the development and publication of these performance measures was provided by the USGS Climate Research \& Development Program, USGS Environments Program, and USGS Wetland and Aquatic Research Center. 


\section{Contents}

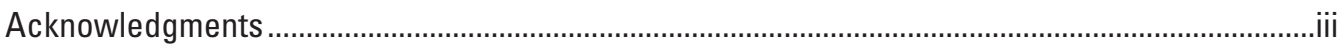

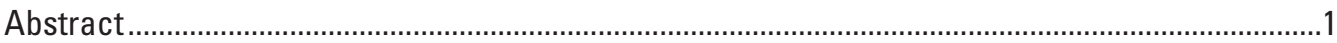

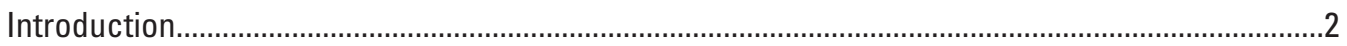

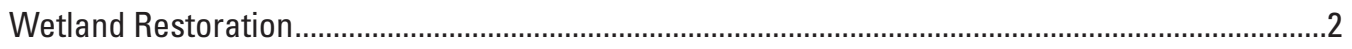

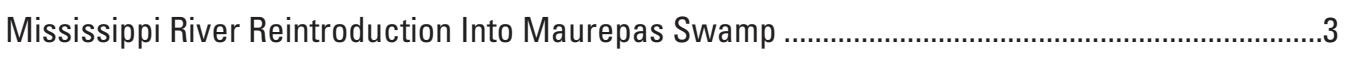

Targeted Wetland Habitats of Maurepas Swamp ……….........................................................

Performance Measures and Adaptive Management................................................................5

PM1: Establishing a Hydrologic Regime Consistent With Swamp Forest Sustainability..........8

Performance Measure Discussion and Literature .........................................................8

Hydrology Performance Measure ..............................................................................

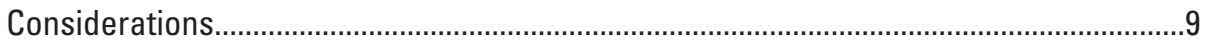

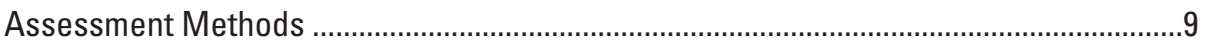

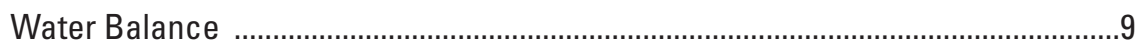

Flooding and Drought........................................................................................11

Sediment Deposition and Scour.............................................................................11

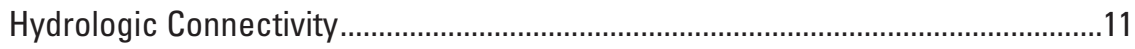

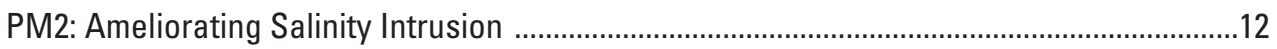

Performance Measure Discussion and Literature ....................................... 12

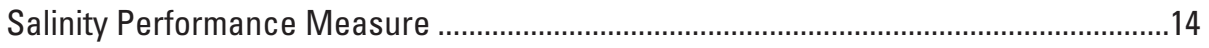

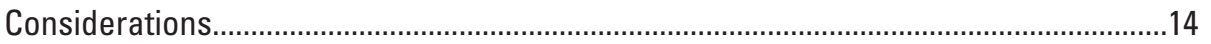

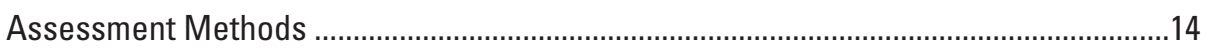

PM3: Increasing Rates of Soil Surface Elevation Gain ......................................................16

Performance Measure Discussion and Literature ......................................................17

Soil Surface Elevation Performance Measure …………..............................................18

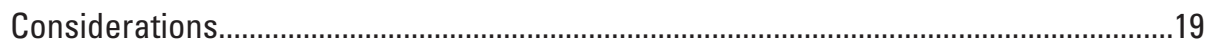

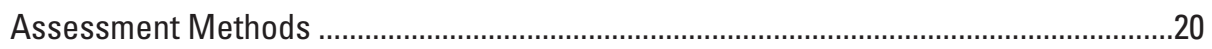

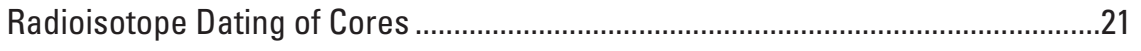

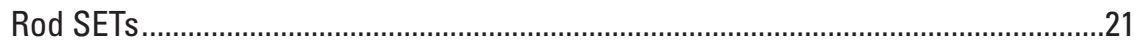

Repetitive Surveying of SETs by Using High-Precision d/RTK-GPS and cGPS ......22

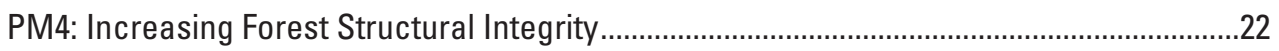

Performance Measure Discussion and Literature .........................................................22

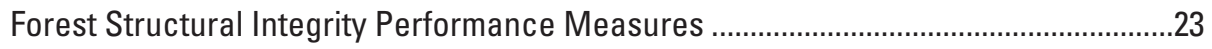

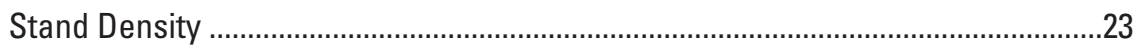

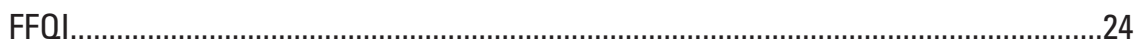

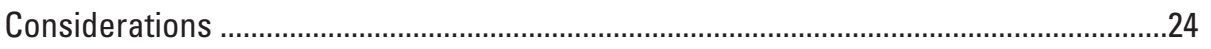

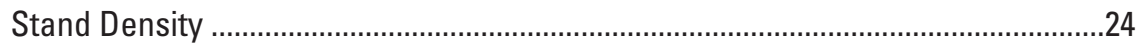

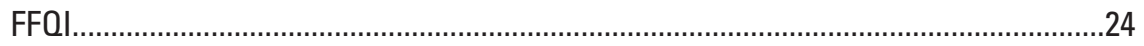

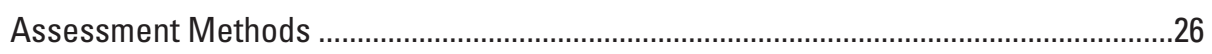

PM5: Facilitating Nutrient Uptake and Retention ..............................................................26 
Performance Measure Discussion and Literature...........................................................27

Nutrient Uptake and Retention Performance Measure ................................................27

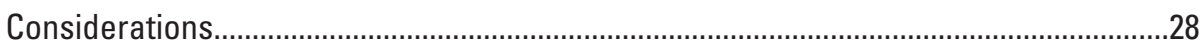

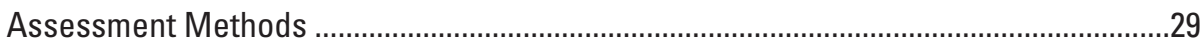

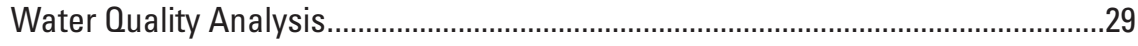

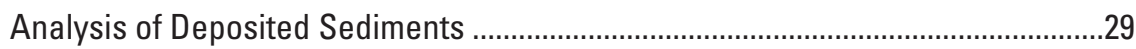

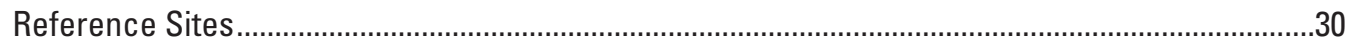

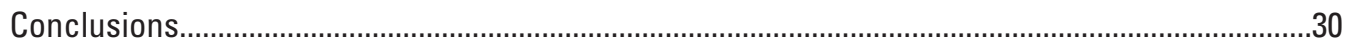

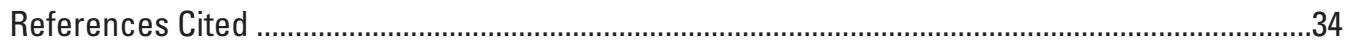

Appendix 1. Current Plot and Data Availability of Potential Relevance for

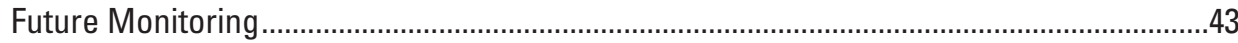

\section{Figures}

1. Map showing location and certain features of a proposed Mississippi River reintroduction into Maurepas Swamp, Louisiana, including the area of potential project influence...

2. Map showing condition classification of forested wetlands in the Maurepas Swamp, Louisiana, project area.

3. Photographs showing representative Coastwide Reference Monitoring System stations within the condition classification for forested wetlands within the Maurepas Swamp, Louisiana, project area

4. Graphs showing acceptability ranges for mean time between events in which coastal swamp forests in Maurepas Swamp, Louisiana, impacted by a Mississippi River reintroduction into Maurepas Swamp $A$, are connected to diverted river water and $B$, undergo 2-year periods with water levels low enough for tree regeneration

5. Graph showing stand basal area in relation to salinity in pore water and surface water samples from Coastwide Reference Monitoring System stations and other studies in coastal swamp forests in Louisiana...

6. Graphs showing pore water acceptability thresholds of 1.3 practical salinity units (psu) and $0.8 \mathrm{psu}$, respectively, for coastal swamp forests influenced by a Mississippi River reintroduction into Maurepas Swamp, Louisiana, related to whether the forest $A$, is primarily baldcypress or $B$, has a preponderance of water tupelo in mixed culture or monoculture

7. Graph showing acceptability ranges around a target of 8-9 millimeters per year for vertical land motion of the wetland, or wetland soil surface elevation change, of coastal swamp forests impacted by a Mississippi River reintroduction into Maurepas Swamp, Louisiana

8. Diagram showing the components of vertical land motion of the wetland for Maurepas Swamp, Louisiana, relative to the tide gage characteristics of the National Oceanic and Atmospheric Administration tide gage at Grand Isle, Louisiana. 
9. Graph showing acceptability ranges around a 45-percent target for stand density index and a leaf area index of 2.9 square meters per square meter for coastal swamp forests impacted by a Mississippi River reintroduction into Maurepas Swamp, Louisiana

10. Graph showing acceptability ranges around a 12.3-percent target for change in forested floristic quality index scores of coastal swamp forests impacted by

a Mississippi River reintroduction into Maurepas Swamp, Louisiana

11. Graph showing nitrate loading acceptability ranges around a target of 11.25 grams of nitrogen per square meter per year associated with a Mississippi River reintroduction into Maurepas Swamp, Louisiana

12. Map showing locations of potential reference sites, including actively monitored swamp stations associated with the Coastwide Reference Monitoring System, for monitoring the success of specific performance measures associated with the operation of a Mississippi River reintroduction into Maurepas Swamp, Louisiana

\section{Tables}

1. Rates of accretion of surface sediments measured by using short-term and long-term techniques in coastal swamp forests in Louisiana

2. Trends and notes for vertical land motion of the wetland soil surface from 2010 to 2016 at nine Coastwide Reference Monitoring System stations located in the Maurepas Swamp, Louisiana, project area derived from surface elevation tables having fairly continuous records

3. Ranges of coefficient of conservatism score assignment and general criteria for plants occurring in coastal forested wetlands and adjacent marsh habitat in Louisiana

4. Time table for initiating components of the monitoring plan for a Mississippi River reintroduction into Maurepas Swamp, Louisiana. 


\section{Conversion Factors}

U.S. customary units to International System of Units

\begin{tabular}{rcc}
\hline Multiply & By & To obtain \\
\hline ton, short $(2,000 \mathrm{lb})$ & Mass & \\
\hline
\end{tabular}

International System of Units to U.S. customary units

\begin{tabular}{|c|c|c|}
\hline Multiply & By & To obtain \\
\hline \multicolumn{3}{|c|}{ Length } \\
\hline centimeter $(\mathrm{cm})$ & 0.3937 & inch (in.) \\
\hline millimeter $(\mathrm{mm})$ & 0.03937 & inch (in.) \\
\hline meter $(\mathrm{m})$ & 3.281 & foot $(\mathrm{ft})$ \\
\hline kilometer (km) & 0.6214 & mile (mi) \\
\hline kilometer (km) & 0.5400 & mile, nautical (nmi) \\
\hline meter $(\mathrm{m})$ & 1.094 & yard (yd) \\
\hline \multicolumn{3}{|c|}{ Area } \\
\hline square meter $\left(\mathrm{m}^{2}\right)$ & 0.0002471 & acre \\
\hline hectare (ha) & 2.471 & acre \\
\hline square kilometer $\left(\mathrm{km}^{2}\right)$ & 247.1 & acre \\
\hline square meter $\left(\mathrm{m}^{2}\right)$ & 10.76 & square foot $\left(\mathrm{ft}^{2}\right)$ \\
\hline hectare (ha) & 0.003861 & square mile $\left(\mathrm{mi}^{2}\right)$ \\
\hline square kilometer $\left(\mathrm{km}^{2}\right)$ & 0.3861 & square mile $\left(\mathrm{mi}^{2}\right)$ \\
\hline \multicolumn{3}{|c|}{ Volume } \\
\hline liter $(\mathrm{L})$ & 33.81402 & ounce, fluid (fl. oz) \\
\hline liter $(\mathrm{L})$ & 2.113 & pint (pt) \\
\hline liter $(\mathrm{L})$ & 1.057 & quart (qt) \\
\hline liter $(\mathrm{L})$ & 0.2642 & gallon (gal) \\
\hline liter $(\mathrm{L})$ & 61.02 & cubic inch $\left(\mathrm{in}^{3}\right)$ \\
\hline \multicolumn{3}{|c|}{ Flow rate } \\
\hline cubic meter per second $\left(\mathrm{m}^{3} / \mathrm{s}\right)$ & 70.07 & acre-foot per day (acre-ft/d) \\
\hline cubic meter per second $\left(\mathrm{m}^{3} / \mathrm{s}\right)$ & 35.31 & cubic foot per second $\left(\mathrm{ft}^{3} / \mathrm{s}\right)$ \\
\hline cubic meter per second $\left(\mathrm{m}^{3} / \mathrm{s}\right)$ & 22.83 & million gallons per day $(\mathrm{Mgal} / \mathrm{d})$ \\
\hline \multicolumn{3}{|c|}{ Mass } \\
\hline $\operatorname{gram}(\mathrm{g})$ & 0.03527 & ounce, avoirdupois (oz) \\
\hline kilogram (kg) & 2.205 & pound avoirdupois (lb) \\
\hline \multicolumn{3}{|c|}{ Density } \\
\hline gram per cubic centimeter $\left(\mathrm{g} / \mathrm{cm}^{3}\right)$ & 62.4220 & pound per cubic foot $\left(\mathrm{lb} / \mathrm{ft}^{3}\right)$ \\
\hline
\end{tabular}

Temperature in degrees Celsius $\left({ }^{\circ} \mathrm{C}\right)$ may be converted to degrees Fahrenheit $\left({ }^{\circ} \mathrm{F}\right)$ as

$$
{ }^{\circ} \mathrm{F}=\left(1.8 \times{ }^{\circ} \mathrm{C}\right)+32 .
$$





\title{
Performance Measures for a Mississippi River Reintroduction Into the Forested Wetlands of Maurepas Swamp
}

\author{
By Ken W. Krauss, ${ }^{1}$ Gary P. Shaffer, ${ }^{2}$ Richard F. Keim, ${ }^{3}$ Jim L. Chambers, ${ }^{3}$ William B. Wood, ${ }^{4}$ and \\ Stephen B. Hartley ${ }^{1}$
}

\section{Abstract}

The use of freshwater diversions (river reintroductions) from the Mississippi River as a restoration tool to rehabilitate Louisiana coastal wetlands has been promoted widely since the first such diversion at Caernarvon became operational in the early 1990s. To date, aside from the Bonnet Carré Spillway (which is designed and operated for flood control), there are only four operational Mississippi River freshwater diversions (two gated structures and two siphons) in coastal Louisiana, and they all target salinity intrusion, shellfish management, and (or) the enhancement of the integrity of marsh habitat. River reintroductions carry small sediment loads for various design reasons, but they can be effective in delivering freshwater to combat saltwater intrusion and increase the delivery of nutrients and suspended fine-grained sediments to receiving wetlands. River reintroductions may be an ideal restoration tool for targeting coastal swamp forest habitat; much of the area of swamp forest habitat in coastal Louisiana is undergoing saltwater intrusion, high rates of submergence, and lack of riverine flow leading to reduced concentrations of important nutrients and suspended sediments, which sustain growth and regeneration, help to aerate swamp soils, and remove toxic compounds from the rhizosphere.

The State of Louisiana Coastal Protection and Restoration Authority (CPRA) has made it a priority to establish a small freshwater river diversion into a coastal swamp forest located between Baton Rouge and New Orleans, Louisiana, to reintroduce Mississippi River water to Maurepas Swamp. While a full understanding of how a coastal swamp forest will respond to new freshwater loading through a Mississippi River reintroduction is unknown, this report provides guidance based on the available literature for establishing performance measures that can be used for evaluating the effectiveness of a Mississippi River reintroduction into the forested wetlands

\footnotetext{
${ }^{1}$ U.S. Geological Survey.

${ }^{2}$ Southeastern Louisiana University.

${ }^{3}$ Louisiana State University Agricultural Center.
}

${ }^{4}$ State of Louisiana Coastal Protection and Restoration Authority. of Maurepas Swamp (project PO-29 of the Coastal Wetlands Planning, Protection and Restoration Act) and aid in adaptive management of the project. PO-29 is a small river reintroduction in scope, and through its operation, it will provide information about the feasibility and reasonable expectations for future river reintroduction projects targeting coastal swamp forests in Louisiana.

Located near Garyville, Louisiana, the Mississippi River reintroduction into Maurepas Swamp project is being designed to deliver a maximum flow of 57 cubic meters per second $\left(\mathrm{m}^{3} / \mathrm{s}\right)$ (or about 2,000 cubic feet per second $\left[\mathrm{ft}^{3} / \mathrm{s}\right]$ ) directly from the river, but with a maximum flow through the outflow channel of $42 \mathrm{~m}^{3} / \mathrm{s}$ ( or $1,500 \mathrm{ft}^{3} / \mathrm{s}$ ) available for at least half of the year. The river reintroduction will divert Mississippi River water through channelized flow and surface water to impact approximately 16,583 hectares (ha) of wetland habitat, much of which is swamp forest and swamp forest transitioning into marsh habitat. The Mississippi River reintroduction into Maurepas Swamp and associated outfall management features collectively should facilitate connectivity of water between the Mississippi River and the entire project area.

At any given location, hydrologic connectivity should occur at intervals between twice yearly and once per decade, and hydrologic management must allow the potential for water drawdowns to foster tree regeneration every 3-13 years. The river reintroduction is also anticipated to maintain salinity in swamp forests dominated by Taxodium distichum (baldcypress) to less than 1.3 practical salinity units (psu) and maintain salinity in mixed baldcypress and Nyssa aquatica (water tupelo) swamp forests to less than $0.8 \mathrm{psu}$. The river reintroduction should promote soil surface elevation gains of 8-9 millimeters per year ( $\mathrm{mm} / \mathrm{yr}$ ) (range, $4.9-12.1 \mathrm{~mm} / \mathrm{yr}$ ) to offset relative sea-level rise and keep total river water nitrate $\left(\mathrm{NO}_{3}^{-}\right)$loading into Maurepas Swamp to about 11.25 grams $(\mathrm{g})$ of nitrogen $(\mathrm{N})$ per square meter per year $\left(\mathrm{m}^{-2} \mathrm{yr}^{-1}\right)$ (range, 7.1-15.4 $\mathrm{g} \mathrm{N} \mathrm{m}^{-2} \mathrm{yr}^{-1}$ ) to promote near complete uptake of $\mathrm{NO}_{3}{ }^{-}$by the vegetation in the receiving wetlands and reduce impacts to water quality in adjacent and connected water ways (for example, Blind River) and Lake Maurepas. With these performance measures maintained over time, we further expect swamp forest stands to realize improvements in stand 
density index of as much as 30-45 percent of maximum values for the stand type while maintaining an overstory leaf area index of 2.0-2.9 square meters per square meter or higher as swamp forests recover from decades of low flow, saltwater intrusion, reduced nutrients, and surface elevation deficits associated with isolation from the Mississippi River.

Associated with these performance measures are two major uncertainties: (1) an assumption that we can rely on existing data, literature, and modeling from coastal swamp forests to establish these performance measures and (2) an unknown time frame for evaluating these performance measures. Some performance measures can be assessed quickly, such as those associated with hydrology and nutrient uptake. Some performance measures, such as changes in soil surface elevation and forest structural integrity, could take longer to assess. Once performance measures are assessed across different time scales, however, adjustments to operations of the Mississippi River reintroduction into Maurepas Swamp can be swift. The proposed performance measures are ideal targets, mostly without specific consideration of practical, operational constraints. The measures are intended to be the basis by which adaptive management of the diversion structures can be evaluated. The measures are defined without regard to current conditions so that project success can be evaluated on net outcomes rather than specific change from existing conditions. We expect that the Mississippi River reintroduction into Maurepas Swamp will slow degradation and extend the life of the swamp for decades to centuries.

\section{Introduction}

Extensive anthropogenic modifications within the historical flood plain of the lower Mississippi River have affected the stability of coastal swamp forests by reducing the influx of sediments, which are essential for offsetting subsidence (Salinas and others, 1986; Pezeshki and others, 1987, 1990; Day and others, 2000). Additionally, lack of freshwater flow has caused anaerobic conditions and decreased plant productivity, which along with increased saltwater intrusion have led to conversion of vast areas of swamp forest to marsh and open water. If current trends persist, approximately 93,000 additional hectares (ha) of swamp forest are expected to be degraded or killed in Louisiana by the year 2050 (Chambers and others, 2005).

The Coastal Wetlands Planning, Protection and Restoration Act project PO-29, River Reintroduction Into Maurepas Swamp, will be the first dedicated river diversion project into the forested wetlands of Louisiana designed specifically for swamp forest restoration, the goal being to reduce or minimize loss of swamp forest habitat in the project area through the reintroduction of Mississippi River water. Thus, the implementation and success, or potential shortcomings, of a Mississippi River reintroduction into Maurepas Swamp will have broad application to wider scale coastal swamp forest restoration efforts. Specific performance measures need to be developed before the construction of the Mississippi River reintroduction to allow for evaluation of restoration effectiveness and to support the development of an adaptive management plan. The U.S. Geological Survey, in cooperation with the Coastal Protection and Restoration Authority (CPRA) of Louisiana and two universities, was charged with helping to develop these performance measures. The goal of this report is to provide potential performance measures of forested wetland response in advance of the project's implementation based upon the available literature to provide managers with metrics for rating the effectiveness of a small Mississippi River reintroduction into Maurepas Swamp.

\section{Wetland Restoration}

Restoration provides one of the best opportunities to offset losses of ecological functions and services when wetland ecosystems become degraded. While the concept is theoretically simple, the last few decades of research have shown wetland restoration to be a difficult task. Restoration can include a number of different types of projects ranging from creation of new wetlands to enhancement of ecological services. We follow the definition of ecological restoration as "the process of repairing damage caused by humans to the diversity and dynamics of indigenous ecosystems" (Jackson and others, 1995, p. 71).

Three primary goals should transcend every restoration project (Harris and Hobbs, 2001). First, projects should attempt to restore the vegetative structure of the wetland previously lost or being enhanced. Thus, a restored swamp forest should indeed look like a swamp forest and meet specific quantitative criteria. Many evaluations of wetland restoration success do attempt to quantify structure, but often end there. The second goal is function. Wetlands should not only resemble the appearance of the natural wetland type targeted, but also restore some of the processes lost during wetland degradation. It is often more important to focus on a few attainable key functions rather than a collection of many (Carey, 2013). If those few functional attributes are restored over a reasonable time frame, then other attributes are also expected to return over time. The structural and functional attributes assessed, however, should be related strongly to the third goal-resilience. Resilience is defined as "a system's capacity to maintain structure and function in the presence of stress" (Rapport and others, 1998, p. 397). Without built-in resiliency, wetland restoration fails because the functional gain through initial restoration is eventually lost regardless of effort.

Coastal Louisiana has been the focus of numerous restoration projects, ranging from targeted (for example, marsh creation) to opportunistic (for example, incidental dredge releases, Stagg and Mendelssohn, 2010; river diversion for flood control, Day and others, 2012). Rates of coastal wetland loss and degradation continue to be high 
in Louisiana; however, some restoration ideas hold promise by maintaining benefits through rehabilitating or mimicking natural processes. For example, the Wax Lake Outlet was constructed as a flood relief offshoot from the Atchafalaya River and not as a restoration project, but it has created emergent deltaic splay wetlands in Atchafalaya Bay from the diverted sediments (including bedload) (Shaw and others, 2013). The State's Master Plan (State of Louisiana, 2012) includes several large land-building sediment diversions along the Mississippi River south of New Orleans that are key components of that plan in long-term land building and maintenance of existing wetlands.

In contrast, small freshwater river diversions deliver less sediment to wetlands by way of their original design standards to provide salinity reduction to salinizing brackish marshes and oyster reefs (for example, Caernarvon freshwater diversion) and to preserve freshwater marshes under threat of saltwater intrusion (for example, Davis Pond freshwater diversion) (Nyman, 2014). Whereas the Davis Pond freshwater diversion channel and outflow area traverses some coastal swamp forest, the outflow's direct influence is primarily to marsh and open water areas because the diversion's operation targets salinity distribution in the Barataria Bay Estuary.

The Mississippi River reintroduction into Maurepas Swamp project (fig. 1) will be the first river diversion dedicated solely to the restoration and rehabilitation of a Louisiana coastal swamp forest. Maurepas Swamp includes approximately 77,550 ha of forested wetlands dominated by Taxodium distichum (baldcypress) and Nyssa aquatica (water tupelo); however, isolation from natural Mississippi River flooding, relative sea-level rise, and land use impacts are driving this swamp forest to submerge and transition into marsh and open water (Effler and others, 2007; Shaffer and others, 2009a).

\section{Mississippi River Reintroduction Into Maurepas Swamp}

Maurepas Swamp was cut off from the natural connection to the Mississippi River at Bayou Manchac in 1814, and this closure was made permanent in 1826 by the State of Louisiana (H. Buras, CPRA, written commun., 2016). This is the underlying cause of the swamp's decline since, and what the Mississippi River reintroduction into Maurepas Swamp proposes to ameliorate (Shaffer and others, 2016), albeit at a much smaller scale. The engineering and design of a river reintroduction from the Mississippi River, through Hope Canal, and into the southern portion of Maurepas Swamp began in 2001 and was developed to the 30-percent design stage through the Coastal Wetlands Planning, Protection and Restoration Act in a partnership between the State of Louisiana and the U.S. Environmental Protection Agency. The Water Resources Development Act of 2007 conditionally authorized the construction of the "Small Diversion at Hope Canal" project under the Louisiana Coastal Area (LCA) program. The CPRA decided to pursue the project outside the LCA program and funded engineering and design up to the 95-percent design level. The CPRA has also filed for a joint permit with the U.S. Army Corps of Engineers and Louisiana Department of Natural Resources for construction. The Gulf Environmental Benefit Fund, through the National Fish and Wildlife Foundation, is supporting the CPRA's development of these performance metrics and other activities needed for preconstruction monitoring and adaptive management planning, with anticipation of Resources and Ecosystems Sustainability, Tourist Opportunities, and Revived Economies of the Gulf Coast States Act (RESTORE Act: https://www.restorethegulf.gov/) funds being used for implementation of the project.

The diversion structure has been designed with a capability to divert up to 57 cubic meters per second $\left(\mathrm{m}^{3} / \mathrm{s}\right)$, or about 2,000 cubic feet per second $\left(\mathrm{ft}^{3} / \mathrm{s}\right)$, of water from the Mississippi River, but the outfall channel further restricts flow to carry a maximum of $42 \mathrm{~m}^{3} / \mathrm{s}$ (or about $1,500 \mathrm{ft}^{3} / \mathrm{s}$ ) of river water to Maurepas Swamp over at least half of the year, which may distribute more than 5,000 kilograms of nitrate $\left(\mathrm{NO}_{3}^{-}\right)$ and 1,000 tons of fine sediment to the basin each day (fig. 1). Under the current operational plan, maximum flows will occur from January to July and will involve different release scenarios (for example, pulsed), but whether specific maximum flow rates can be maintained in a given year depends on Mississippi River stage, as well as whether specific performance measures of ecosystem health are met over time. Periodic drawdown of Maurepas Swamp waters to yield exposed soils sufficient to facilitate forest regeneration is also required, which might be accomplished by diversion structure closure to facilitate greater water losses from Maurepas Swamp than inputs during climatically dry periods. Indeed, the broad goals of this project are to improve the overall health of Maurepas Swamp as a forested wetland by offsetting future soil surface submergence, reducing salinity intrusion, enhancing existing forest productivity and health, promoting forest regeneration, preventing conversion of forest to marsh or open water, and potentially converting some marsh back to forest. Here, we outline several important performance measures that can be used by the State of Louisiana to monitor the effectiveness of the Mississippi River reintroduction into Maurepas Swamp in reducing forest decline through improved structure, function, and resilience and provide a starting point for developing an operations, maintenance, monitoring, and adaptive management (OMMAM) plan for the project.

\section{Targeted Wetland Habitats of Maurepas Swamp}

The Mississippi River reintroduction will enter the wetlands of Maurepas Swamp from the Mississippi River south of the project area, at approximately river mile 144 near Garyville, Louisiana (fig. 1), connecting to a reengineered version of the current Hope Canal, and deposit river water into 


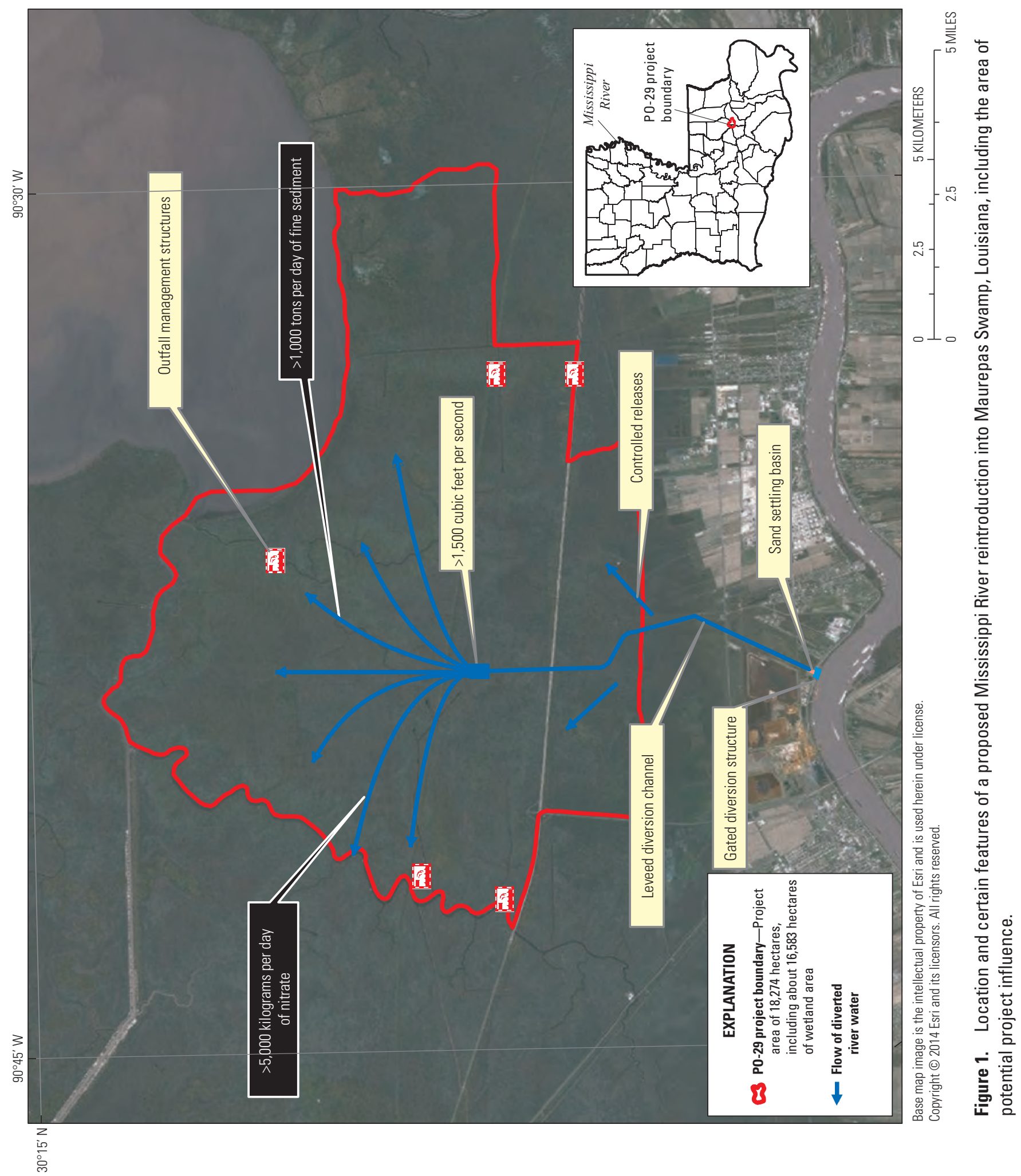


the swamp forest. Then, facilitated by various outfall management features along the way and throughout the project area, reintroduced river waters will enter forests with various degrees of canopy cover that eventually transition to marsh.

Maurepas Swamp contains 82,755 ha of combined swamp forest and marsh habitat (Effler and others, 2007). This wetland ecosystem is typical for coastal swamp forests of Louisiana except that its areal coverage remains higher than other areas where wetland loss has been more severe. While we focus on swamp forests in this report, especially baldcypress and water tupelo communities, Maurepas Swamp contains vibrant wetland plant communities of many species ranging from diverse freshwater swamp forests and aquatic environments to low-salinity marsh (app. 1, table 1-1). Many types of wetland plant assemblages will be affected in some way by a Mississippi River reintroduction.

Not all of the greater than 82,000 ha of wetland area of Maurepas Swamp will be influenced by a river reintroduction through Hope Canal. The project will directly influence approximately 16,583 ha of wetland habitat, the majority of which is either forested wetland or marsh adjacent to forested wetland (fig. 2). As canopy cover lessens, marsh species become more dominant along a continuum of reduced cover (fig. 3). The Mississippi River reintroduction into the Maurepas Swamp project area contains at least 4,991 ha of closed forest canopy habitat; 1,920 ha of open canopy wetland (marsh) habitat; and 9,672 ha of transitional forest habitat (forests with an intermediate degree of canopy coverage) (fig. 2) (Keim and others, 2010a). While this report focuses on performance measures for the swamp forest habitat, increasing overall marsh health where conversion to swamp forest is untenable is also important. Performance measures will include a distinction among these three categories of forest condition only when necessary.

\section{Performance Measures and Adaptive Management}

Ecological restoration involves manipulation of multiple key environmental processes simultaneously. Results of those manipulations are difficult to predict because of complex linkages among manipulations and their consequences for current and future ecological structure. Therefore, projects must be prepared to measure the results of restoration efforts and to adjust restorative management appropriately (Thom, 2000). Restoration targets and performance measures are important for tracking the success of a river reintroduction project to establish whether it has been successful over variable time frames (for example, 5, 10, 20, 50 years) such that changes can be implemented during the project life span as part of an adaptive management framework.

Performance measures should incorporate differentiation between natural variability and realized changes in condition due to project implementation, a realistic expectation of response time, and cost-effective and reasonable monitoring programs (Hijuelos and Reed, 2013). Previous data collection efforts may help distinguish natural variability and past trajectories of change from the influences that a river reintroduction may have on some performance measures. Monitoring should be expanded to fill gaps in current data collection efforts that will be needed to evaluate river reintroduction influences comprehensively.

This Mississippi River reintroduction into Maurepas Swamp is unprecedented in application. While surrogates of river reintroductions related to sediment releases from dams, spillways, or navigation channels that inadvertently convey sediments, nutrients, or freshwater are available in the literature (Hughes, 1997; Day and others, 2012; Middleton and Souter, 2016), the performance measures described herein were developed on the basis of what is known about healthy coastal swamp forests rather than on past restoration successes. It is expected that the Mississippi River reintroduction into Maurepas Swamp will increase the health of the Maurepas Swamp ecosystem by delivering fine sediment and nutrient subsidies and simultaneously flushing stagnant water and toxic metabolites from the system to keep salinity intrusion within established limits. The State's earliest coastal restoration plan recognized the specific role of freshwater diversions on restoration (see Nyman, 2014), as follows:

Project benefits for these diversions [freshwater] primarily focus on the change effected on a salinity regime and the response of the existing biological resources to this change. However, because the fine silt and clay portions of riverine sediment loads are uniformly distributed throughout the flow, some accretion or wetland enhancement results as a secondary benefit of these projects (State of Louisiana, 1993, p. 49).

Performance measures for Maurepas Swamp target land quality, landscape quality, geophysical processes, and water quality (in the sense of Hijuelos and Reed, 2013). Where the Mississippi River reintroduction project fails to meet specific performance measures over annual performance periods, the OMMAM will detail specific procedures, within the range of the diversion structure's operations, to move performance measures from unacceptable to acceptable ranges whenever possible. Herein, we follow the advice provided in a recent review of successful wetland restoration assessment strategies, which suggests that "scientists should focus on one or two key objectives [for wetland recovery programs], $* * *$ and engineer the system to optimize those objectives. Then, once the basic engineering is done, let nature fill in the details as it pleases" (Carey, 2013, p. 76). We are targeting a few specific performance measures that focus on structure, function, and resilience of the forested wetlands as potentially conferred by the operation of a small freshwater river diversion to reintroduce Mississippi River water into Maurepas Swamp and which collectively should also be representative of holistic ecosystem 


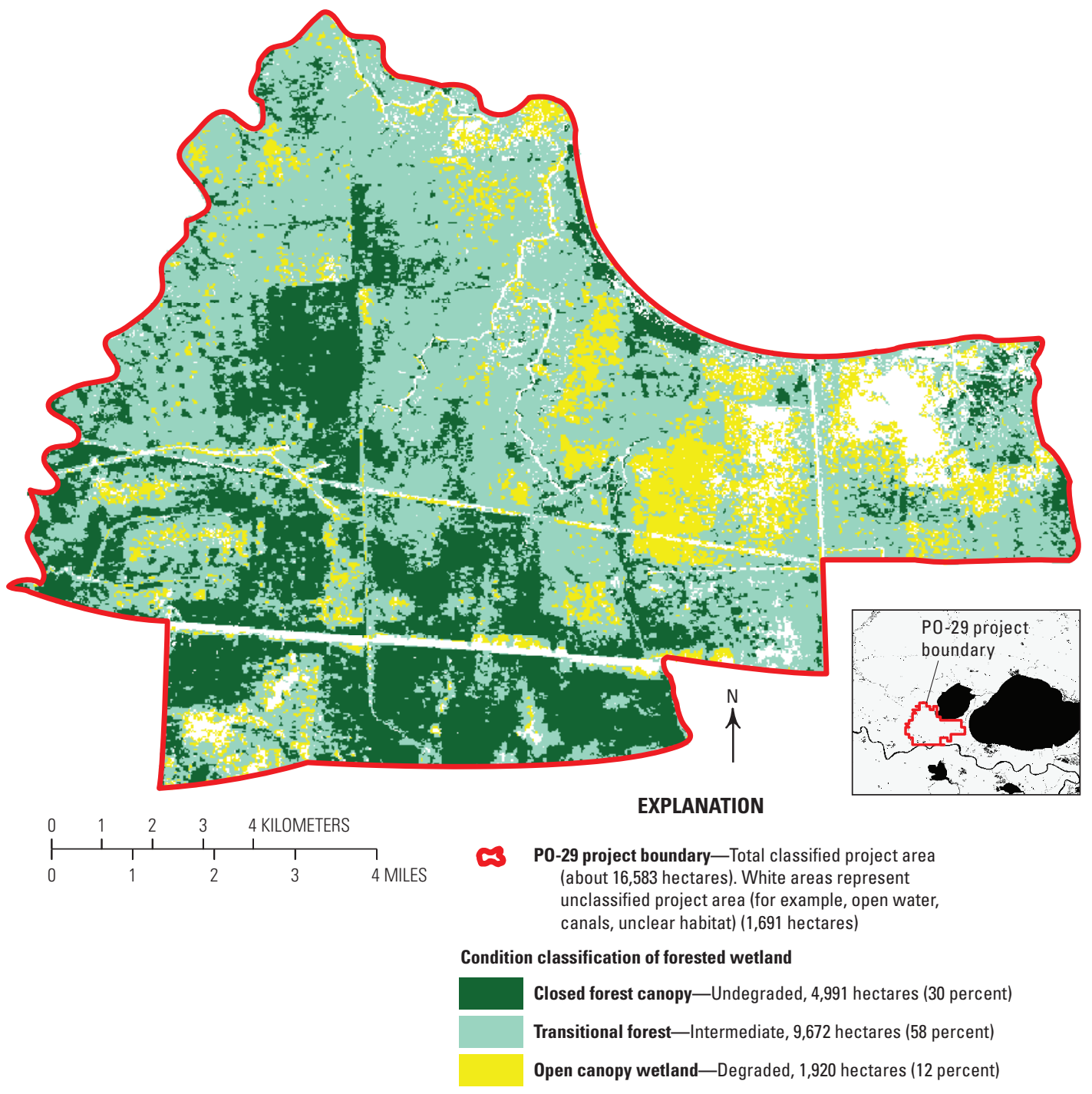

Figure 2. Condition classification of forested wetlands in the Maurepas Swamp, Louisiana, project area (modified from Keim and others, 2010a). "Open canopy wetland” represents predominately marsh. 
A

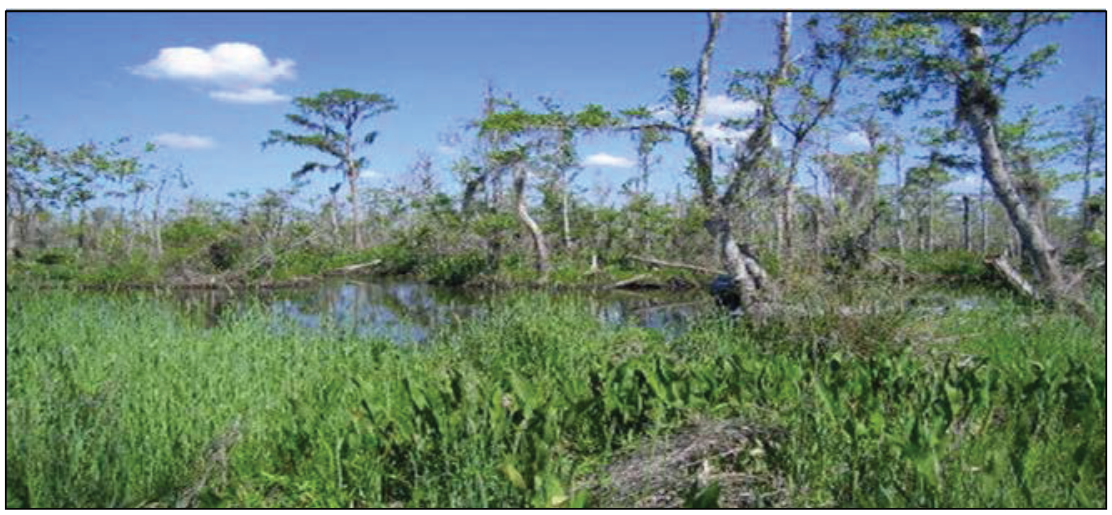

B

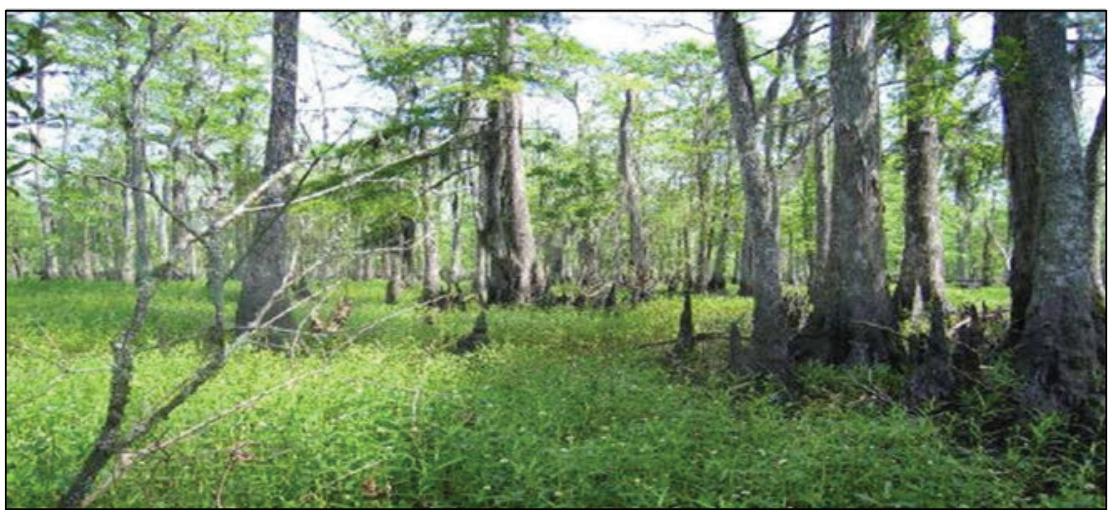

C

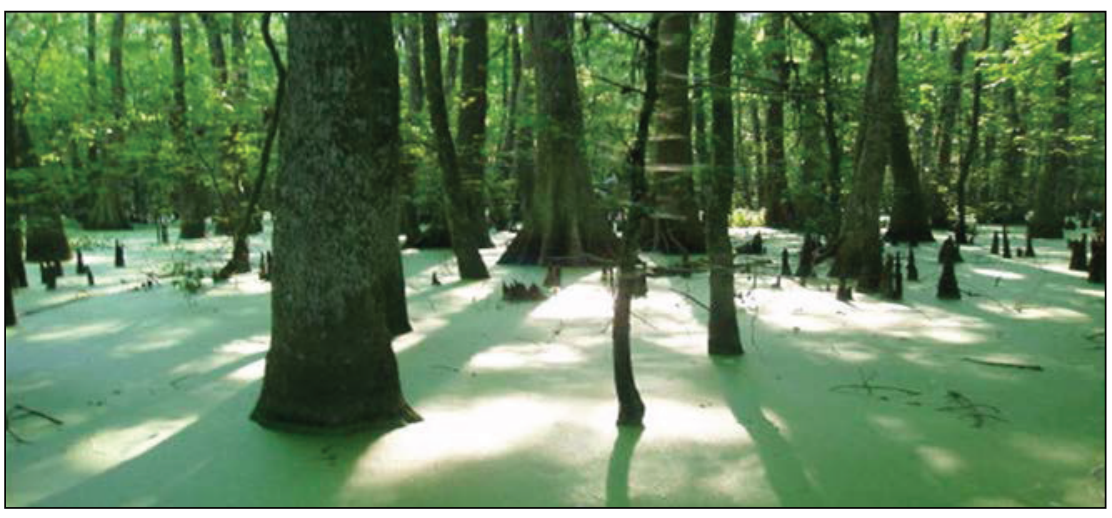

Figure 3. Representative Coastwide Reference Monitoring System (CRMS)

stations within the condition classification for forested wetlands (depicted in fig. 2) within the Maurepas Swamp, Louisiana, project area (from Wood and others, 2017). $A$, Open canopy wetland. $B$, Transitional forest. $C$, Closed forest canopy. 
restoration success once those specific performance measures are met.

While other criteria may be used to assess trends in additional parameters, such as fish and wildlife usage, five broad performance measures have been selected to influence adaptive management action. The five performance measures being proposed include

1. Establishing a hydrologic regime consistent with swamp forest sustainability (PM1)

2. Ameliorating salinity intrusion (PM2)

3. Increasing rates of soil surface elevation gain (PM3)

4. Increasing forest structural integrity (PM4)

5. Facilitating nutrient uptake and retention (PM5)

For each performance measure, we identify the data that have been collected in the past (and where), summarize those data briefly, and recommend a target that is relevant for Louisiana coastal swamp forests. We then identify what criteria should be met for each specific performance measure and outline some methods that may be used for assessing performance measures. The majority of the method assessments that we suggest are best implemented in advance of the construction of the Mississippi River reintroduction into Maurepas Swamp. Additional past and current data collection efforts from Maurepas Swamp of potential relevance, but not specifically included in performance measures sections (PM1-PM5), are reported in appendix 1. We rely primarily on data in the publications cited herein; additional data from the Coastwide Reference Monitoring System (CRMS) stations are available from the CPRA Coastal Information Management System [CIMS] (Coastal Protection and Restoration Authority of Louisiana, 2016).

\section{PM1: Establishing a Hydrologic Regime Consistent With Swamp Forest Sustainability}

Hydrologic processes are integral to wetland ecosystems, so ecological restoration requires reestablishing the natural processes governing water flow and residence times. Wetlands are defined by hydrologic regime, which includes both the mean and variability of the suite of hydrologic processes governing ecological and biogeochemical processes. Dimensions of the hydrologic regime are (1) the water balance, such as inflows, outflows, precipitation, and evaporation; (2) system states induced by the hydrologic balance, such as flooding and drought; (3) geomorphic effects of the water balance, such as sediment deposition and scour; and (4) hydrologic connectivity, which is flux of water and its organic and inorganic constituents. Restoration of all dimensions of the hydrologic regime is not necessarily expected, and monitoring all dimensions of the hydrologic regime is expensive. The challenge is to construct a monitoring program that recognizes and addresses the most important facets.

\section{Performance Measure Discussion and Literature}

The most important components of the water balance for ecological functioning of riverine forested wetlands are inflows and outflows. Swamps with low flow and stagnant water, and those that are impounded, tend to have lower productivity and may convert to other wetland types (Harms and others, 1980; Mitsch and others, 1991; Shaffer and others, 2009a). Related to this hydrologic stress are frequency, duration, and timing of inundation or drying periods. Variability of conditions is essential for functioning of wetlands (for example, Wilcox and others, 2002), and lack of inundation or lack of drying each drive systems toward conversion to another ecotype. Much of the Mississippi River reintroduction into Maurepas Swamp project area is nearly permanently inundated, so drying events are appropriately a focus even if practically they may be difficult to achieve. Frequency of drying events relates to biogeochemical processes but also to tree regeneration: periodic low water is required for seedlings to become established (DeBell and Naylor, 1972; Hook, 1984; Keim and others, 2006). Operational achievement of these goals may be difficult, but there may be opportunities to develop heuristic management strategies that increase hydrologic variability. For example, a dry winter may be suggestive of a delayed opening of the diversion structure to full volume to later in the spring in order to facilitate greater soil exposure for regeneration and rapid early seedling growth across Maurepas Swamp.

Changes in flow alter sediment budgets of swamp channels and therefore alter flood plain channel morphology (Kroes and Kraemer, 2013). Headwater flow that transports sediment generates channels with distinctly different morphology than backswamp channels. Natural levees formed by channels with sediment transport are important for forested wetland ecology because they are geomorphically distinct, higher elevation sites that host different tree species than do backswamps (Hodges, 1997). Morphologic changes are also closely related to changes in nutrient budgets; for example, phosphorus $(\mathrm{P})$ is an occasional limiting nutrient in forested wetlands for which budgets are strongly tied to sediment transport (Lockaby and Conner, 1999).

Hydrologic connectivity is strongly associated with inflows and outflows, but it encompasses more than simply the water budget. Nutrient budgets are also strongly affected (Bechtold and others, 2003), as are organisms (Tockner and others, 1999). Flushing of phytotoxins and delivery of nutrients to backswamps are accomplished by connectivity (Noe and others, 2013; Scott and others, 2014), which is a primary hydrologic restoration objective of the Mississippi River reintroduction into Maurepas Swamp. Connectivity to flowing water interacts with local biota (for example, aquatic vegetation) to control water quality and aquatic habitat (Kaller and others, 2015). Overall, the suite of conditions associated with a wetland connected to riverine processes drives deltaic wetlands toward forested cover, but cessation of that connectivity drives them toward emergent cover. In the nearby Bonnet 
Carré Floodway and Bayou LaBranche wetlands, Day and others (2012) found that approximately decadal major riverine flooding and more frequent minor connectivity has maintained forest productivity.

\section{Hydrology Performance Measure}

Successful hydrologic restoration will entail hydrologic variability that reflects variable riverine connection rather than the current stagnant backswamp conditions throughout Maurepas Swamp. Flow of freshwater must be reestablished. The variability in flow will partially be quantified in water depths: deep water reflecting periodic active river connection (about 2 meters $[\mathrm{m}]$ near the diversion structure and gradually less toward Lake Maurepas) will occur at intervals between twice yearly and once per decade (fig. 4). Connectivity that is more frequent will likely lead to ecosystem conversion to open water (if there is no sediment accumulation) or bottomland hardwoods (if there is rapid, deep sediment accumulation); these changes have been observed in natural deltaic development (for example, Faulkner and others, 2009; Keim and others, 2013b). A project that establishes connectivity less frequently than decadal scale will lead to stagnant flood conditions that decrease tree growth and favor transition to marsh. Similarly, fully successful restoration will include low water periods, during which water levels either decrease to expose soil long enough for regeneration to occur (several months during the growing season) or for artificial planting of new cohorts of seedlings to be successful and then remain low enough (less than about $0.5 \mathrm{~m}$ ) throughout two consecutive growing seasons to allow tree seedlings to grow tall enough to avoid inundation and consequent mortality (establishment period); these events should occur no less frequently than at decadal intervals to allow for sustainability of the forest (fig. 4). Drying events that are more frequent than about once per 4 years may lead to conversion to bottomland hardwoods, and drying events less frequent than about 20 years will lead to conversion to marsh or open water (although there is considerable uncertainty on the exact frequency, and the estimates are based on field experience of the authors rather than systematic investigation).

Success in establishing riverine hydrologic conditions will also entail approximately decadal biogeochemical connection between swamps and river water, at a minimum. It is not sufficient for swamps to undergo deep water composed primarily of water from Lake Maurepas or rainfall as in the current, predominantly stagnant condition; the water must move from the diversion structure through all of the swamp to cause the necessary type of inundation. This connection will be evident in similarity between isotopic composition of floodwaters and Mississippi River water or by alternate tracers such as temperature, electrical conductivity, and perhaps supplemented by concentrations of reactive water constituents such as nitrate or metals that can also yield information about how the wetland is processing floodwaters. Connectivity to riverine flow will also be considered biogeochemically sufficient only if there is evidence of appropriate sediment movement into swamps, either by formation of sediment-competent channels or deposition of fine sediments on the swamp floor and swamp vegetation. Success will entail connectivity to flowing waters, measured either by evidence of sediment deposition or by tracer studies (stable isotopes, electrical conductivity, temperature) in backswamps matching those in flowing waters during a high-flow period and compared to the same measures during low-flow conditions (fig. 4).

\section{Considerations}

Quantification of riverine hydrology from an ecosystem perspective is not easily accomplished by using current scientific understanding because riverine hydrology includes a multidimensional suite of processes for which variability is just as important as mean conditions (Toner and Keddy, 1997; Muneepeerakul and others, 2008). To date, there has been no systematic treatment of this problem sufficient for planning or evaluation of hydrologic restoration of similar coastal swamp forest, and the suite of controlling processes must be mainly inferred from case studies. It is essential that there be revision of measures chosen to evaluate restoration performance on the basis of continued progress in scientific understanding.

\section{Assessment Methods}

Because of the multifaceted aspects of the performance measure related to hydrology, methods are divided into the four components listed previously.

\section{Water Balance}

For the Mississippi River reintroduction into Maurepas Swamp, one objective is to modify the water balance by increasing both inflows and outflows (that is, generate flowthrough to reduce stagnant conditions). Inflow to the area from the river reintroduction is monitored at the diversion structure from the Mississippi River. Flow monitoring elsewhere in the project area is difficult because of low velocities, unchannelized flow, or two-way flow within channels. Therefore, no routine monitoring within the project area is proposed. Spot checks of flow into, within, and out of the area are warranted for the purpose of adaptive management; for example, although detailed hydraulic modeling indicates that sheet flow will be generated by the project, it is probable that geomorphic adjustments in channels or development of new channels will to some degree cause channelized flow to occur where it is not expected and perhaps not desired. Monitoring for flow deviation from the design may be done at intervals during the life of the project. This monitoring may consist of synoptic surveys from boats and in aerial imagery. The schedule for these checks is adaptive, but initially target weekly, monthly, and then seasonal surveys as the system stabilizes. Permanent flow gages may be deployed if specific areas are difficult to assess. 
Multiple times yearly

to once per decade

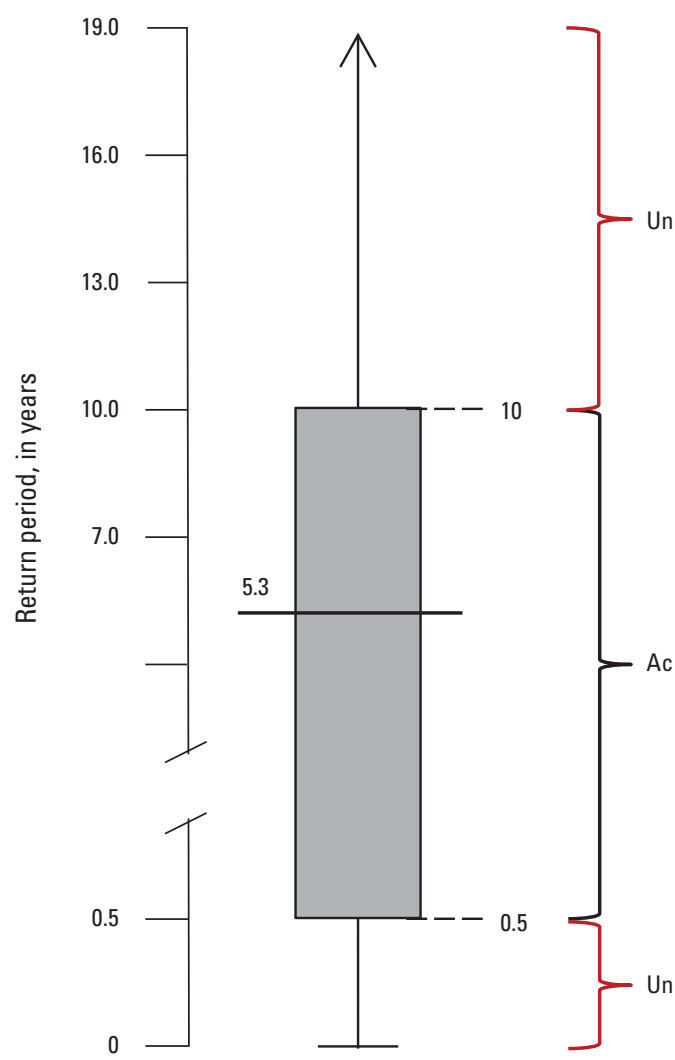

Connectivity
$\boldsymbol{B}$ decadal intervals

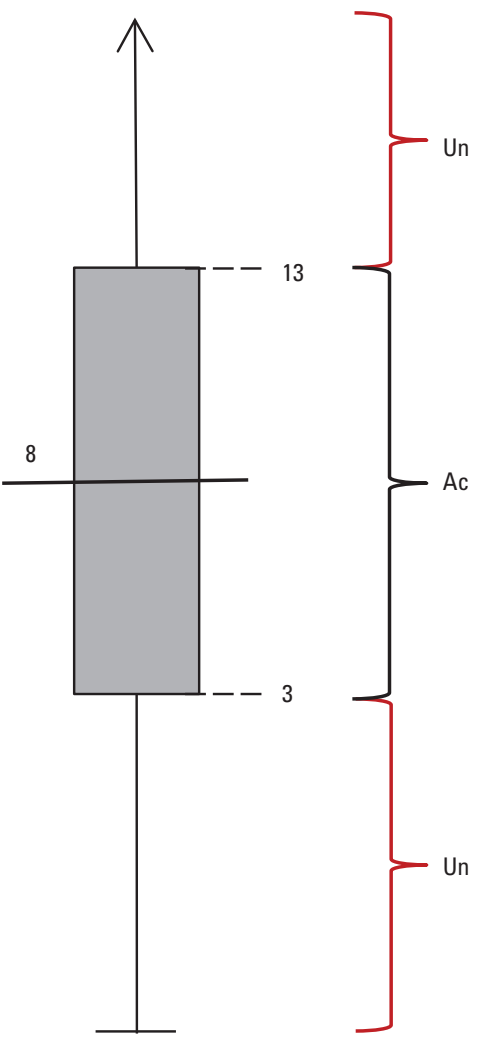

Low water

\section{EXPLANATION}

Target value for performance measure (PM) - A single value or range of values; established by the literature

Standard deviation (or range) in measurement of mean target

PM value-Based on available data

- - Actual value that represents \pm 1 standard deviation of the mean

Ac Acceptable - Values within standard deviation of measurement for target PM. This range may trigger management action

Un Unacceptable - Values outside mean target PM threshold and standard deviation of measurement for target PM. This range should trigger management action

Figure 4. Acceptability ranges for mean time between events in which coastal swamp forests in Maurepas Swamp, Louisiana, impacted by a Mississippi River reintroduction into Maurepas Swamp $A$, are connected to diverted river water (0.5-10 years, mean of 5.3 years) and $B$, undergo 2 -year periods with water levels low enough for tree regeneration (3-13 years, mean of 8 years). 
Precipitation is not expected to be affected by the river reintroduction project, but there is a chance that evaporation and (or) evapotranspiration may be changed if vegetation communities change substantially because environmental stress can affect both evaporation and plant water usage (Krauss and Duberstein, 2010; Abtew and Melesse, 2013; Krauss and others, 2015). Monitoring evaporation and transpiration is not proposed because it is expensive and technically difficult, and changes in the water balance by changing evaporation are likely to manifest as other, more easily monitored properties of the ecosystem.

\section{Flooding and Drought}

A defining feature of wetlands is water depth on site. One restoration objective of the Mississippi River reintroduction into Maurepas Swamp is to decrease flood depth and duration by raising the swamp floor and offsetting subsidence (see section "PM3: Increasing Rates of Soil Surface Elevation Gain"). While subsidence and surface elevation are treated elsewhere in this report, it is also necessary to quantify water surface elevation in addition to simple water depth because the combination of water surface elevation and water depth data can enhance surface elevation monitoring (that is, water surface elevation is a function of both depth and ground elevation) and because it is an important metric in any hydraulic modeling needed as part of adaptive management.

The most effective way to measure water depth by using current technology is by pressure transducer. Water monitoring stations often consist of transducers set into the ground in slotted pipes (wells) to a depth below expected minimum water table elevation. To ensure constant elevation of the monitoring stations, pipes may be mounted on rods that have been driven to refusal into more consolidated sediments underlying the swamp and potentially paired in some cases with salinity sensors (see section "PM2: Ameliorating Salinity Intrusion"). Elevation of the top of the mounting rod is measured by using a Global Positioning System (GPS) receiver and leveling techniques and ideally coordinated with other monitoring efforts in the project area.

Monitoring stations will be beneficial both in channels and in current backswamps that are not routinely hydrologically connected to channels because infrequent flooding of these backswamps is an important hydrologic signature to reestablish. Selection of the specific monitoring locations will include logistical considerations pertaining to, for example, accessibility of sites and colocation with other monitoring. The objective of the network of monitoring stations will be to identify how the river reintroduction affects water depth in the swamps at sufficient spatial and temporal resolution to identify whether the sheet flow objective is being met.

In addition to ground-based measurements, remote sensing would benefit assessment associated with water depth changes throughout the project area, even where not accessible to field crews. Satellite radar data are useful for measuring water level fluctuations, especially when ground-based measurements are available for calibration, as they will be in this monitoring, and when there is emergent vegetation on the water surface (Lu and others, 2005; Alsdorf and others, 2007). For example, radar data from the SENTINEL-1 satellite of the European Commission and the European Space Agency (or similar) may be used to measure water levels. Specific satellite data to be used must remain flexible into the future of the monitoring effort because of rapidly evolving technology.

\section{Sediment Deposition and Scour}

The primary sediment monitoring mechanisms in the swamp would be a combination of techniques that capture short-term processes, such as surface elevation tables, and techniques that capture longer term processes, such as radioisotope dating of cores (see section "PM3: Increasing Rates of Soil Surface Elevation Gain"). All hydrologic monitoring can also include visual description of sediment movement by field observation: description of turbidity (not quantitative) and any evidence of deposition such as recent sediment on the swamp floor and on trees. These field notes will be important for adaptive management and adaptive monitoring spatially across the project area. Also, sediment pathways can be quantified and monitored by using remote sensing such as Landsat satellite data (https://landsat.usgs.gov/), as has been done in the Atchafalaya River Basin (Allen and others, 2008).

Periodic measurement of channel dimensions of navigable channels throughout the project area will benefit project monitoring. Dimensions can be quantified by low-cost cross sections, but repeated bathymetric surveys would provide better data. Locations of measurements may match preconstruction surveys as much as possible. Remeasurement at least quarterly initially, but with decreased frequency as appropriate once the rates of observed changes are quantified might reduce costs over time. More frequent measurements are called for in the months following changes in diversion structure operations or other significant events.

\section{Hydrologic Connectivity}

A key objective for the Mississippi River reintroduction is to increase water flow through Maurepas Swamp. An ideal method to trace water flow paths is to monitor the concentrations of stable isotopes in water throughout the project area. The natural occurrence of stable isotopes of oxygen $(\mathrm{O})$ and hydrogen $(\mathrm{H})$ in water (delta oxygen $18\left[\delta^{18} \mathrm{O}\right]$ and delta deuterium $\left[\delta^{2} \mathrm{H}\right]$, where delta $[\delta]$ indicates proportion relative to a standard), is commonly used in tracing water residence times and flow paths (Kendall and McDonnell, 1998). The physical processes governing $\delta^{18} \mathrm{O}$ and $\delta^{2} \mathrm{H}$ in natural waters are related to evaporation and condensation, such that waters from varying geographic and climatologic sources or having undergone evaporation in place have distinctive signatures (Kendall and Caldwell, 1998). These tracers have been used successfully to determine water sources in streams (Maloszewski and Zuber, 1993) and wetlands (Lott and Hunt, 2001). The project area will likely yield good resolution between water sources 
because of the wide variation in geographic origin of contributing water. Specifically, water in the Mississippi River is isotopically much lighter (lower $\delta^{18} \mathrm{O}$ and $\left.\delta^{2} \mathrm{H}\right)$ than local rainfall in Louisiana because of the dominant origin of river water at higher latitudes (Kendall and Coplen, 2001), and these tracers have been used successfully in the Atchafalaya River Basin to identify flow paths (Scott and others, 2014). Assessment will benefit from isotope samples obtained monthly for at least 1 year prior to initiation of diversion structure operation to establish a baseline, then monthly following construction and after major changes in operations, and opportunistically and heuristically after that. Samples may be taken from both channelized flow and backswamp water throughout the project area.

Another way to trace water movement through the swamp is via water temperature at certain times of year. In spring, the Mississippi River is cooler than local water because it carries snowmelt from the northern parts of its watershed. Thus, thermal tracing of water may be possible at that time of year. Measurements of water temperature may be made during all field visits and may include measurements of water temperature in the channelized river reintroduction flow as reference when practically possible. Inexpensive temperature data loggers can be added opportunistically to monitoring stations for other parameters. Water temperature can also be monitored by remote sensing to allow distributed measurement of connectivity between channels and backswamps that are typically inaccessible to field crews. There are several satellites available for this monitoring (Mertes, 2002; Ritchie and others, 2003), and testing of sensitivity for each one at the onset of the river reintroduction would be beneficial to determine which is most appropriate for this application. Swarzenski and others (2008) showed that the ratio of calcium to magnesium was an effective tracer of river connection in two Louisiana marshes, and novel tracers such as this could be tested and developed in the Maurepas Swamp project area. Finally, a simple tracer of water flow that may be less time consuming to measure is electrical conductivity as a surrogate for total dissolved solids. Measurements of electrical conductivity may be made during field visits to include the channelized flow from the Mississippi River reintroduction as reference when practically possible.

\section{PM2: Ameliorating Salinity Intrusion}

Baldcypress-water tupelo forests in coastal Louisiana are subject to a number of important stressors including, but not limited to, drought, flooding, nutrient limitation, salinity, and herbivory (Effler and others, 2006, 2007; Shaffer and others 2009a, 2016). Dramatic anthropogenic changes began to take place during the almost complete logging of Louisiana's natural baldcypress-water tupelo forests in the late 1800 s and the early 1900s (Conner and Toliver, 1990). Logging operations with associated railroads and canals to remove timber severely disturbed the landscape. The advent of pull-boat logging near the end of this period also created scars and barriers to drainage and flow (Mancil, 1980); Maurepas Swamp is heavily impacted by these hydrologic impediments. Oil and gas exploration and extraction motivated the building of canals, pipelines, and roads with berms or ditches, further disrupting the landscape and increasing saltwater intrusion into marshes and swamps. Near the end of the extensive logging operations, and concomitant with oil and gas extraction, building of levees and other structures became much more common in the effort to reduce flooding from rivers and bayous. The opening of shipping channels added even more ways for storm driven tidal surges and salinity to enter Maurepas Swamp through Lake Pontchartrain (Shaffer and others, 2009b).

All of these activities play a major role in changing natural processes such as pulse flooding, seasonal drainage, and saltwater intrusion into coastal baldcypress-water tupelo forests of Louisiana. Some areas of baldcypress and water tupelo never recovered from the combination of harvesting and landscape changes brought about during this period. Other coastal forest areas that had begun to recover and grow have, more recently, begun to decline from increased periods of flooding, deeper flooding, and saltwater intrusion (Conner and others, 2014; Shaffer and others, 2016). Continuing or increasing relative sea-level rise, subsidence, and deep faulting serve to exacerbate the problems of increased flooding and saltwater intrusion. Maurepas Swamp is succumbing to these stressors and continues to degrade.

\section{Performance Measure Discussion and Literature}

Current and future sea-level rise and the changes that have occurred in connectivity of wetland forests to streams and rivers have caused and will continue to cause increased stress on wetland forests from saltwater intrusion and the combined effects of salinity and flooding (Salinas and others, 1986). Stagnant water and the lack of flood pulses have decreased growth and led to tree mortality. Saltwater intrusion has most prominently occurred in the forests of southern Louisiana that are dominated by baldcypress and water tupelo (Wicker and others, 1981; DeLaune and others, 1987; Allen, 1992). Once salinity enters a swamp, release from stress requires the input of freshwater for flushing of salt and stagnant waters.

The relation of salinity to swamp forest composition was noted as far back as 1938 by Penfound and Hathaway (1938), who indicated levels of salinity in several coastal forest areas of southeastern Louisiana and pointed out the ability of baldcypress trees to grow in saline water with as much as $0.53-0.89$ percent salinity, or 5.3-8.9 practical salinity units (psu), where swamp and marsh intergraded one another. While this level of salinity seems high on the basis of our current understanding of baldcypress salt tolerance, they also indicated that water tupelo only survived at 0.0 percent salinity in their study areas, an observation of critical importance for Maurepas Swamp. Montz and Cherubini (1973) studied a backswamp area of the LaBranche wetlands on the 
southwestern edge of Lake Pontchartrain and found that only baldcypress was present at the ecotone between swamp and marsh. They reported dead trees within the swamp that were presumed to have died after a hurricane in 1915 and reinvaded by baldcypress prior to 1936 .

More recent and broader analyses of the effects of salinity on baldcypress-water tupelo forests in Louisiana have been presented (Hoeppner and others, 2008; Krauss and others, 2009). As part of a larger comparison of degrading baldcypress-water tupelo forests in the southeastern United States, Krauss and others (2009) selected two transects along salinity gradients in coastal Louisiana. Along each of the two transects they selected a degraded, a moderately degraded, and a healthy baldcypress-water tupelo forest. They hypothesized that degraded sites near marshes were likely degraded by proximity to the estuary and that salinity would be the major stressor causing forest degradation. Overall, Krauss and others (2009) found a general increase in forest species degradation from freshwater sites to sites with higher salinity. Sites with salinities below $0.7 \mathrm{psu}$ had trees with basal areas greater than 87 square meters per hectare $\left(\mathrm{m}^{2} / \mathrm{ha}\right)$, while those with salinities above $1.3 \mathrm{psu}$ had basal areas less than $40 \mathrm{~m}^{2} / \mathrm{ha}$. Krauss and others (2009) were able to demonstrate clear association between salinity and relative changes along each transect in site productivity (tree height, basal area, basal area increment), species composition (overall or within canopy positions), and soil nutrient content for multiple swamp forests.

For Maurepas Swamp, studies of similar focus have been undertaken by Hoeppner and others (2008). Freshwater enters Lake Maurepas and associated swamps primarily from the north and west from rivers draining to the Lake Pontchartrain Basin. Salinity enters Lake Maurepas from the east during periods of low freshwater flow and with easterly and southerly winds, especially during tropical storms. The more saline waters entering from Lake Pontchartrain through Pass Manchac create an area of oligohaline or brackish water on the eastern side of Lake Maurepas (Shaffer and others, 2009a). Hoeppner and others (2008) selected 40 plots around the lake to represent various swamp areas east, south, and west of the lake (see app. 1). They followed changes in flooding, salinity, soil nutrients, biomass, basal area, and other factors from the driest period in 2000-2001 to 2004. They found that sample plots to the east of the lake (lake sites), both north and south of Pass Manchac, had the highest mean salinity, approaching $2.2 \mathrm{psu}$. Areas to the southeast had mean salinity of about $1.0 \mathrm{psu}$, and plots to the south of the lake, bounded by freshwater contributing canals and other waterways, had a mean salinity near 0.9 psu. Mean salinities in all of the study areas were highest in the drought year of 2000-2001 and decreased in the remaining years, but always remained highest east of the Lake, or the area most distant from the proposed outflow from the Mississippi River reintroduction into Maurepas Swamp.
Study of additional swamp forests, for example, along the Cape Fear River, North Carolina, have shown that nearly daily pulsing with salinity higher than 2.0 psu begins the conversion process from forest to marsh (Hackney and others, 2007); similar salinity thresholds were found for Louisiana, South Carolina, and Georgia swamp forests (Krauss and others, 2009). Hackney and others (2007) blame the conversion not only on salinity but also on the microbial sulfate reduction to hydrogen sulfide, which is toxic to plants. This situation is further exacerbated by concentrated salinities during drought cycles (for example, mean salinities of less than 2 psu can reach 4.5 psu during drought with extremes over $6 \mathrm{psu}$; Cormier and others, 2013). Drought pulsing of salinity is different from either chronic salinity exposure or infrequent and short-lived salinity pulses associated with tropical storm surges or wind guided impulses associated with their approach. Chronic exposure causes the most deleterious response to swamp forests (fig. 5).

In Louisiana, a network of wetland study stations associated with CRMS was established in 2003 (Steyer and others, 2003) and expanded to include swamp forests in 2007. This system was based on the concept that environmental drivers of coastal vegetation change are flooding and salinity. The process on forested sites involves sampling of vegetation on specified plots and the collection of vegetation information along with measures of flooding and salinity (Folse and others, 2014). Salinity sampling involves discrete collections near the CRMS boardwalks (established to access sample stations) and consists of (1) sampling salinity intermittently throughout the year when the boardwalk is accessed and (2) sampling at each herbaceous vegetation station (nine herbaceous vegetation stations per CRMS station) during vegetation sampling twice annually.

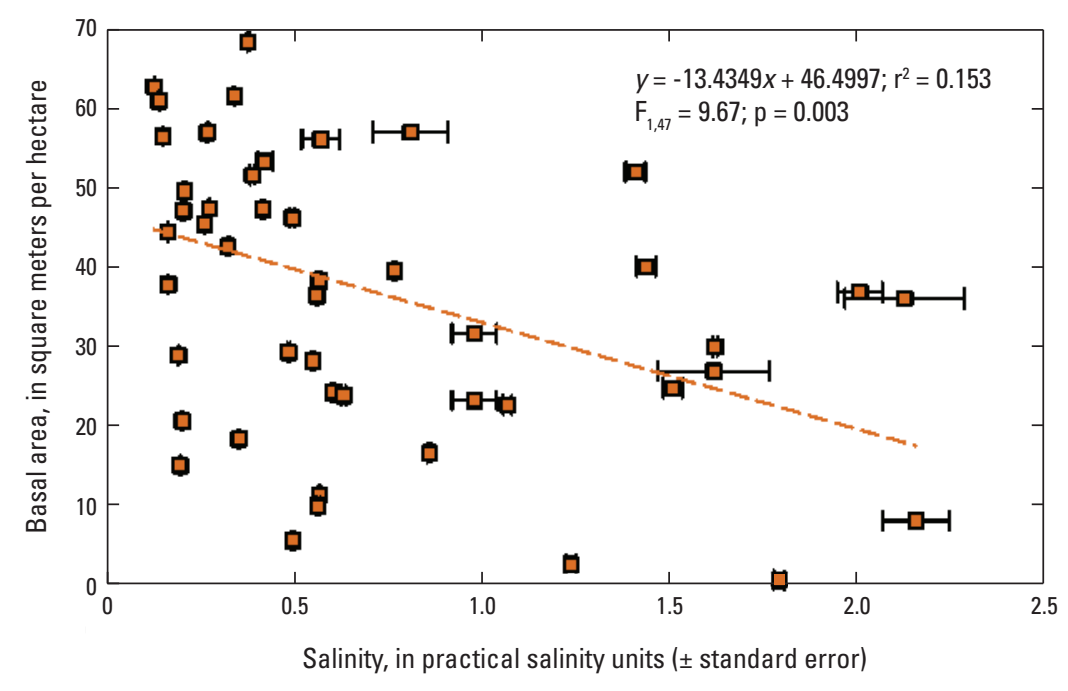

Figure 5. Stand basal area in relation to salinity in pore water and surface water samples from Coastwide Reference Monitoring System (CRMS) stations and other studies (Hoeppner and others, 2008; Krauss and others, 2009) in coastal swamp forests in Louisiana. Data and additional site characteristics are reported in appendix 1, table 1-2. 
All swamp forests in Louisiana harboring mean salinities greater than (>) 2 psu were actively converting to marsh (Krauss and others, 2009). Additionally, average basal area decreased with an increase in salinity across multiple sites in coastal Louisiana $(\mathrm{p}=0.003)$, with no basal area data from sites having a mean salinity of 2.2 psu or greater because they are no longer forested (fig. 5). This basal area trend with salinity matches an early survey of coastal Louisiana marshes that included degraded swamp forests, for which Chabreck (1972) reported a mean pore water salinity of 1.90 plus or minus $( \pm)$ 1.40 (standard error) psu for a marsh interspersed with baldcypress and observed no baldcypress or water tupelo beyond that salinity concentration. Allen (1994) recorded salinity of 1.2 to $3.7 \mathrm{psu}$ alongside individual baldcypress trees for 1 year following Hurricane Andrew; however, these individual trees were occurring in isolation within functional marsh, streamside, or levee environments where basal area descriptors were not feasible.

\section{Salinity Performance Measure}

The majority of swamp forests dominated by baldcypress and water tupelo are functionally freshwater ecosystems, occurring within their geographic range most often where no seawater salinity influence exists. Salinity currently influences Maurepas Swamp forests, and performance measures must keep salinity below specific thresholds. Pore water salinity in swamp forests of Maurepas Swamp ranged from mean values of 0.81 to 2.16 psu (Hoeppner and others, 2008; Shaffer and others, 2009a). Salinity did vary across years with highs during the 2000-2001 growing season, ranging between 2.0 and $4.5 \mathrm{psu}$, demonstrating the year-to-year variation often present. Furthermore, it should be noted that mean salinity of less than $(<) 2$ psu is far less than reported as salinity tolerance values for baldcypress from short-term, experimental studies on seedlings (Krauss and others, 2007), suggesting that field values be prioritized. We focus specifically on field data.

Likewise, water tupelo, a major constituent of Lake Maurepas, has a low tolerance to salinity (Penfound and Hathaway 1938), probably rarely exceeding chronic concentrations of 1 psu or higher in the field (Krauss and others, 2009) despite evidence to the contrary from short-term, experimental studies on seedlings (Pezeshki, 1987, 1990; Pezeshki and others, 1989; McLeod and others, 1996). Hoeppner and others (2008) showed a drop in the importance value indices of water tupelo from a high of 0.611 at sites with a salinity of 0.98 psu to a low of 0.051 at sites where mean salinity was $2.16 \mathrm{psu}$; at these sites, water tupelo trees were at least present. However, these data suggest that salinity tolerance for water tupelo is below 1.0 psu under field settings, but certainly greater than 0.0 psu reported by Penfound and Hathaway (1938). Marsh surveys conducted by Chabreck (1972) failed to overlap with water tupelo distribution.

Mean annual target pore water salinity values for Maurepas Swamp with the river reintroduction operating at appropriate levels should be less than 1.3 psu for areas with higher concentrations of baldcypress, but below 0.8 psu for areas with higher concentrations of water tupelo or Nyssa biflora (swamp tupelo) (fig. 6). Maximum standard deviation above and below these values, based on pore water measurements taken in Maurepas Swamp, is 0.32 psu (Hoeppner and others, 2008). Therefore, mean annual pore water salinity values above 1.62 psu for forested wetland communities with baldcypress only and above 1.12 psu for forested wetland communities with water tupelo are unacceptable, while salinities below the established thresholds of $1.3 \mathrm{psu}$ and $0.8 \mathrm{psu}$, respectively, are preferred with the Mississippi River reintroduction into Maurepas Swamp.

\section{Considerations}

Since the closing of the Mississippi River-Gulf Outlet (MRGO) Canal, reductions in saltwater intrusion into Lake Pontchartrain and in turn into Lake Maurepas will likely continue, potentially reducing soil pore water salinity in Maurepas Swamp with or without a river reintroduction project. Slightly counter to this, if relative sea level increases more rapidly than do elevations in Maurepas Swamp, river reintroduction management may become more important to salinity reduction over the next few decades. Because salinity response of the dominant tree species in Maurepas Swamp is fairly well known, relaxing the PM2 standards would not be as reasonable as adjusting the management of the river reintroduction.

Although we have outlined soil pore water salinity targets important to permanently or nearly permanently flooded portions of the swamp and to specific dominant tree species, changes in surface elevation and areas that currently have only seasonal flooding (few) develop periods where vadose zone (unsaturated soil) conditions can become important to the survival of baldcypress, water tupelo, and other woody species (Hsueh and others, 2016). Methods of measurement of salinity in the vadose zone are not directly comparable to measurements of pore water salinity, detailed below. We contend that if the health of forests dominated by baldcypress or by baldcypress and water tupelo is maintained or improved under the influences of the Mississippi River reintroduction, then other sentinel plant species of the overstory and understory associated with Maurepas Swamp will be improved as well.

\section{Assessment Methods}

Currently, there are 11 CRMS stations located within the project area and 2 additional stations just northwest of the project area. CRMS stations record salinity and water level continuously and may be used effectively to understand not only the salinity condition before the river reintroduction (for example, app. 1, table 1-2), but also the influence of the structure's operation on reducing salinity over specific time periods after the Mississippi River reintroduction into Maurepas Swamp is underway. CRMS stations do effectively record salinity conditions of wetland parcels from permanent 


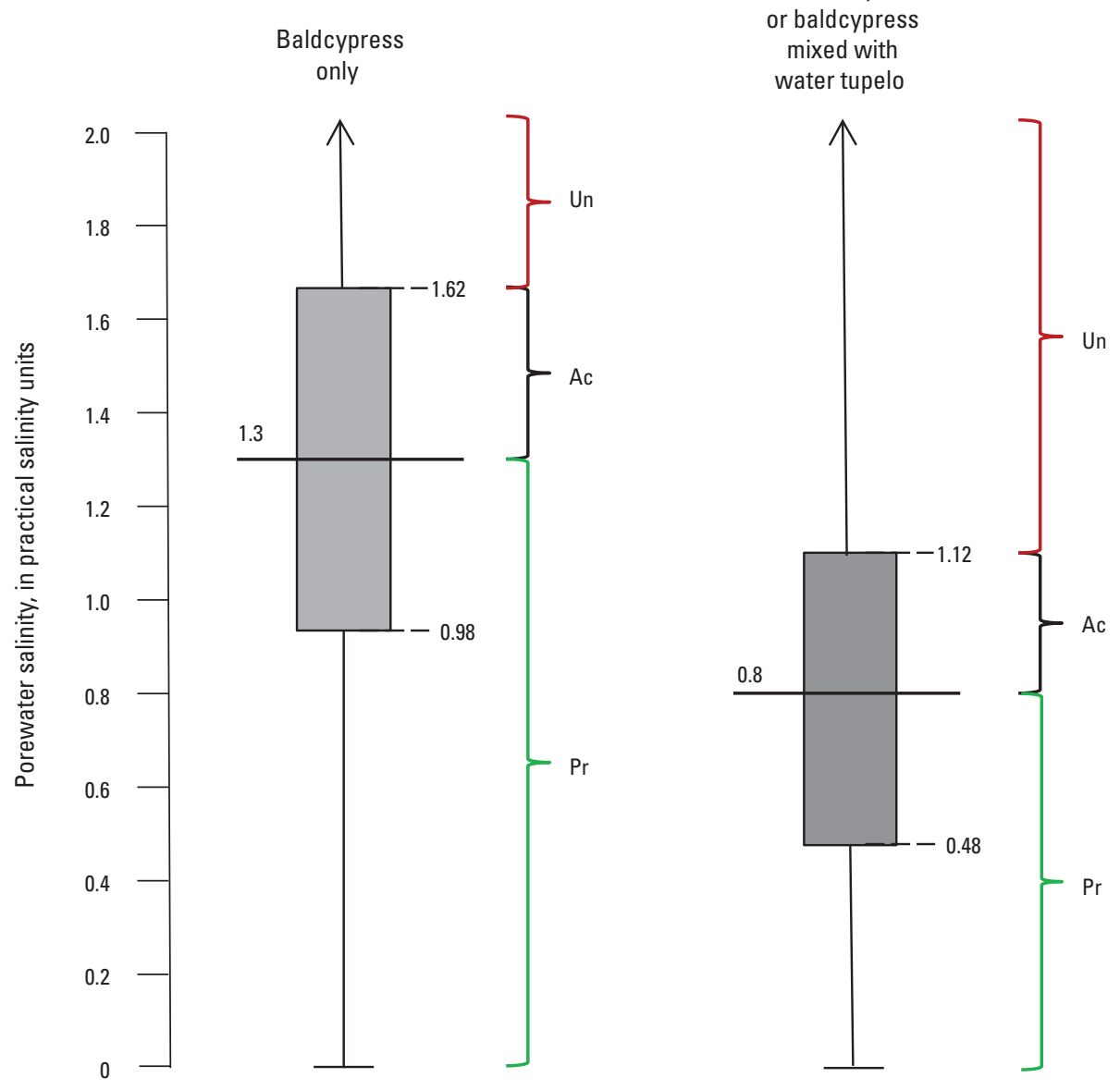

\section{EXPLANATION}

Target value for performance measure (PM) - A single value or range of values; established by the literature

Standard deviation (or range) in measurement of mean target PM value-Based on available data

- - Actual value that represents \pm 1 standard deviation of the mean

Pr Preferred-Values within mean target PM. This range will not trigger management action

Ac Acceptable - Values within standard deviation of measurement for target PM. This range may trigger management action

Un Unacceptable - Values outside mean target PM threshold and standard deviation of measurement for target PM. This range should trigger management action

Figure 6. Pore water acceptability thresholds of 1.3 practical salinity units (psu) and $0.8 \mathrm{psu}$, respectively, for coastal swamp forests influenced by a Mississippi River reintroduction into Maurepas Swamp, Louisiana, related to whether the forest $A$, is primarily baldcypress or $B$, has a preponderance of water tupelo in mixed culture or monoculture. Salinity ranges are associated with maximum standard deviation $(0.32$ psu) reported by Hoeppner and others (2008) recorded for Maurepas Swamp. Salinity thresholds are assumed to represent mean annual pore water salinity. 
standing water locations and thus are often adjacent to and not directly within root zone soils. Pore water salinity measurements added would allow for improved inference from these CRMS stations, and continuous records by using data loggers will match the frequency of in-stream (channel) measurements and surface water measurements on the CRMS sites. Pore water salinity can differ considerably from in-stream or surface water measurements even over short distances in forested wetlands (Day and others, 2007).

In addition to CRMS stations, three additional salinity monitoring tasks would assist in evaluating this performance measure. First, the additional deployment of salinity gages along bayous and small canals that may exhibit greater hydrologic isolation from reintroduced river waters would assist in understanding the distribution of salinity change; many of these new gages can be colocated with hydrology stations used for evaluations described in section "PM1: Establishing a Hydrologic Regime Consistent With Swamp Forest Sustainability." Expanding on continuous salinity recorders from 11 to 20-25, for example, will not only allow for a more robust assessment of salinity change in the entire project area but also will better define the responsiveness of salinity change when storm impact is weighed against river reintroduction management during and after storms. These data could establish how other coastal forests are managed in the future to ameliorate storm surge and salinity pulses.

Second, the new in-stream salinity stations may be paired with measurements of salinity from backswamps not routinely hydrologically connected to channels to relate the two and ensure that the Mississippi River reintroduction into Maurepas Swamp is also having the desired impact on soil pore water salinity throughout the project area. In each environment identified in figure 2 - open canopy wetland, transitional forest, and closed forest canopy - at least three paired in-stream versus pore water salinity gages (continuous data loggers) would benefit the assessment if compared routinely in each environment along the river reintroduction impact gradient. If continuous data loggers are not used, pore water salinity can be assessed from target locations either monthly or quarterly.

Third, at least a few continuous salinity gages may be added between the Maurepas Swamp project area (across Lake Maurepas) and the western regions of Lake Pontchartrain to assess salinity condition not only in the project area but also along gradients toward the northeast to relate specific salinity events (for example, surge, drought) to potential sources of saltwater. This need can be met by many different designs, including additional CRMS stations and other gages already established.

\section{PM3: Increasing Rates of Soil Surface Elevation Gain}

For any coastal swamp forest to persist over time, the elevation of the soil surface must build at rates that exceed the net rise in sea level combined with any elevation losses through subsidence (Cahoon and others, 2006; Webb and others, 2013). The net change in surface elevation relative to sea-level rise is commonly referred to as relative sea-level rise $\left(\operatorname{RSLR}_{\text {wet }}\right)$; the subscript designates that RSLR is specific to the wetland surface in lieu of the survey depths of a tide gage (Cahoon, 2015):

$$
\operatorname{RSLR}_{\text {wet }}=\text { RSLR }-\mathrm{VLM}_{\mathrm{w}}
$$

where

RSLR is the relative sea-level rise trend from the nearest reliable long-term tide gage to the wetland of interest, and

$\mathrm{VLM}_{\mathrm{w}} \quad$ is vertical land motion of the wetland, or wetland soil surface elevation change (Cahoon, 2015).

Thus, a "surface elevation deficit" occurs when the RSLR $_{\text {wet }}$ value is positive, reflecting an incremental loss of elevation relative to sea level over time. Local hydrologic conditions superimposed on sea-level rise can also contribute to surface elevation deficits and are sometimes modeled (Rybczyk and others, 1998) or considered empirically (Conner and Day, 1988). Determination of RSLR ${ }_{\text {wet }}$ and the general surface elevation susceptibility to total submergence can be influenced by the technique used to assess deficits (Cahoon, 2015). For example, the amount of sediment deposited on the soil surface (vertical accretion) does not always correspond directly to $\operatorname{VLM}_{\mathrm{w}}$ (McKee and others, 2007), especially in an inactive delta (Nyman and others, 2006); however, vertical accretion is a large component of $\mathrm{VLM}_{\mathrm{w}}$ in many coastal wetlands (Cahoon and others, 1999; Lovelock and others, 2015). Vertical accretion is commonly measured by using marker horizons (for example, feldspar clay) over short time periods or radioisotopic techniques (for example, cesium $137\left[{ }^{137} \mathrm{Cs}\right]$ or lead $210\left[{ }^{210} \mathrm{~Pb}\right]$ ) over long time periods, although both techniques differ slightly in what they assess. The difference between vertical accretion and actual VLM "shallow subsidence," where accretion is greater than VLM or "soil volume expansion," where VLM is greater than accretion. Tracking VLM ${ }_{w}$ as such is a critical variable for documenting and rating the influence that a Mississippi River reintroduction into Maurepas Swamp would have on RSLR ${ }_{\text {wet }}$ and, thus, offsetting submergence.

Coastal wetlands can actively build soil surface elevation by facilitating the deposition and retention of sediments during floods, stock-piling litter and woody debris, and promoting basal diameter and root volume expansion while limiting organic matter decomposition (Krauss and others, 2014). All of these processes have the potential to be influenced by a connection to the Mississippi River (Day and others, 2012). Sediments and nutrients from river water might contribute directly to sedimentation processes, including sediment deposition and the stimulation of organic matter production to promote surface elevation gain. If nutrient supply from the river reintroduction is very high, however, the greater availability 
of nutrients and (or) other chemical constituents might also stimulate organic matter decomposition (Swarzenski and others, 2008), which might cause surface elevation losses in some settings. The degree to which these mechanisms are relevant to a Mississippi River reintroduction into Maurepas Swamp, as well as the influence the reintroduction may have on facilitating surface elevation gain or loss, is unknown but can be determined as part of postproject monitoring.

\section{Performance Measure Discussion and Literature}

In the Barataria Bay and Verret Basins of Louisiana, water level rise was determined to be 8.5 and 13.7 millimeters per year $(\mathrm{mm} / \mathrm{yr})$, respectively, over a 30 -year period (1956-1986), and vertical accretion of sediments in swamp forests based upon short-term measurements suggested annual deficits of 2.5 and $4.9 \mathrm{~mm} / \mathrm{yr}$, respectively (Conner and Day, 1988). While VLM $\mathrm{w}_{\mathrm{w}}$ was not assessed, compaction of these deposited sediments would likely contribute to even greater surface elevation deficits, indicating that those swamp forests are gradually submerging. This trajectory of gradual swamp forest submergence appears to be consistent within at least some hydrologic basins in Louisiana (DeLaune and others, 1987); the increase in the rate of surface elevation deficit is related to an engineered hydrologic isolation from the Mississippi River since the 1930s (Kesel, 1988), even longer for Maurepas Swamp. Yet, under some circumstances it is possible that healthy soils and root structure might be contributing to soil volume expansion (Patrick and Khalid, 1974), in lieu of subsidence, in isolation from major sediment deposits to reduce soil surface elevation deficits. Brantley and others (2008) suggested that stimulating forest productivity enhances litter-associated vertical accretion (and $\mathrm{VLM}_{\mathrm{w}}$ ) in coastal Louisiana swamp forests. The degree to which vertical accretion translates to $\mathrm{VLM}_{\mathrm{w}}$ in coastal swamp forests is uncertain, but accretion rates measured from different techniques can be high (table 1) and are a critical contributor to $\mathrm{VLM}_{\mathrm{w}}$.

Table 1. Rates of accretion of surface sediments measured by using short-term (feldspar marker horizons) and long-term (cesium 137 $\left[{ }^{137} \mathrm{Cs}\right]$ dating) techniques in coastal swamp forests in Louisiana.

[yr, year; mm/yr, millimeter per year; \pm , plus or minus; SE, standard error of the mean; --, no SE reported]

\begin{tabular}{|c|c|c|c|c|}
\hline Location & Habitat & Record length, yr & $\begin{array}{c}\text { Short-term accretion, } \\
\mathrm{mm} / \mathrm{yr} \pm \mathrm{SE}\end{array}$ & Source \\
\hline Verret Basin & Bottomland hardwood ridge & 0.7 & $2.7 \pm 1.2$ & Conner and Day, 1988 \\
\hline Barataria Basin & Swamp forest & 0.7 & $8.8 \pm--$ & Conner and Day, 1988 \\
\hline Pointe-au-Chene & Bottomland hardwood ridge & 5.7 & $2.7 \pm 0.5$ & Rybczyk and others, 2002 \\
\hline Pointe-au-Chene & Swamp with effluent & 5.7 & $9.7 \pm 0.3$ & Rybczyk and others, 2002 \\
\hline Bayou Chinchuba & Bottomland hardwood ridge & 5.5 & $9.3 \pm 0.1$ & Brantley and others, 2008 \\
\hline Bayou Chinchuba & Backswamp & 5.5 & $10.1 \pm 0.2$ & Brantley and others, 2008 \\
\hline Bayou Chinchuba & Bayou edge & 5.5 & $11.8 \pm 0.3$ & Brantley and others, 2008 \\
\hline Location & Habitat & Record length, yr & $\begin{array}{c}\text { Long-term accretion, } \\
\mathrm{mm} / \mathrm{yr} \pm \mathrm{SE}\end{array}$ & Source \\
\hline Lake Verret & Swamp forest & 21 & $6.3 \pm 3.5$ & DeLaune and others, 1987 \\
\hline Pointe-au-Chene & Swamp forest & 25 & $4.4 \pm 0.6$ & Rybczyk and others, 2002 \\
\hline Pointe-au-Chene & Swamp with effluent & 30 & $5.5 \pm 0.3$ & Rybczyk and others, 2002 \\
\hline LaBranche & Swamp without river input & 56 & $14.0 \pm--$ & Day and others, 2012 \\
\hline LaBranche & Swamp without river input & 56 & $4.3 \pm--$ & Day and others, 2012 \\
\hline Bonnet Carré & Swamp with river input & 56 & $26.0 \pm--$ & Day and others, 2012 \\
\hline Bonnet Carré & Swamp with river input & 56 & $27.0 \pm--$ & Day and others, 2012 \\
\hline
\end{tabular}


Vertical accretion rates from a swamp forest site located in the Lake Pontchartrain Basin of Louisiana ranged from 2.1 to $11.8 \mathrm{~mm} / \mathrm{yr}$ over fairly small spatial scales (Brantley and others, 2008). Rybczyk and others (2002) discovered that waters diverted to coastal swamp forests from a municipal wastewater treatment facility in Louisiana influenced accretion slightly from 4.4 to $5.5 \mathrm{~mm} / \mathrm{yr}$ (based on ${ }^{137} \mathrm{Cs}$ techniques) or from 7.8 to as much as $11.4 \mathrm{~mm} / \mathrm{yr}$ (based on incremental change measured by using marker horizon techniques). River water would have far fewer nutrients (for example, Battaglin and others, 2001) than a wastewater treatment operation, and uptake of nutrients might be rapid and undispersed throughout Maurepas Swamp (Lane and others, 2003). Very little data currently exist to clarify the influences of river reintroductions on $\mathrm{VLM}_{\mathrm{w}}$. Long-term accretion of swamp forests receiving river water from the Bonnet Carré Spillway in Louisiana was $26-27 \mathrm{~mm} / \mathrm{yr}$, whereas swamp forests isolated from river pulses underwent rates of accretion ranging to only half of those values (4.3-14.0 mm/yr) (Day and others, 2012).

Radioisotopic techniques $\left({ }^{137} \mathrm{Cs}\right.$ and $\left.{ }^{210} \mathrm{~Pb}\right)$ make use of marker dates (1964 for ${ }^{137} \mathrm{Cs}$ ) or constant radioactive decay models $\left({ }^{210} \mathrm{~Pb}\right)$ within a soil profile to establish soil accumulation rates over time (Lynch and others, 1989). On coastlines where subsidence below the core is low, these techniques work well as surrogates for tracking $\mathrm{VLM}_{\mathrm{w}}$ over the previous few to many decades preceding core extraction. Thus, a less dramatic change of $1.1 \mathrm{~mm} / \mathrm{yr}$ (over 30 years) versus $3.6 \mathrm{~mm} / \mathrm{yr}$ (over 5.7 years) associated with wastewater loading influences was registered by radioisotopes in Rybczyk and others (2002). DeLaune and others (1987) found accretion rates of $6.3 \mathrm{~mm} / \mathrm{yr}$ around a swamp forest in Lake Verret, Louisiana, which evaluated a 21-year soil profile, although Day and others (2012) found much higher rates of accretion over a 56-year time frame by using ${ }^{137} \mathrm{Cs}$ than were found in any of the previous studies (up to $27.0 \mathrm{~mm} / \mathrm{yr}$ ). In comparison, accretion measured by using radioisotopic techniques ranged from 0.7 to $2.5 \mathrm{~mm} / \mathrm{yr}$ for tidal swamp forests along three rivers in coastal Georgia, leading Craft (2012) to conclude that tidal swamp forests there are not keeping pace with sea-level rise (positive $\operatorname{RSLR}_{\text {wet }}$ ). Surface elevation deficits in coastal swamp forests would occur naturally during periods of higher sea-level rise or subsidence as wetlands migrate inland or disappear (Stagg and others, 2016), as has been documented in many locations over the Holocene (for example, Willard and others, 2003, 2010; Törnqvist and others, 2004).

Determination of RSLR wet by using VLM w $_{\text {estimates }}$ from surface elevation tables (SETs, Boumans and Day, 1993) provides the strongest metric of coastal wetland response to environmental drivers, given enough time. A design modification to the original SET (rod SET, Cahoon and others, 2002) allows rods to be driven to refusal, installed, and surveyed to standards similar to those for tide gages. Since both the SET and the tide gage measure vertical land motion simultaneously and relative to deep anchor depths (10-23 m), SETs and tide gages can be used in tandem to determine RSLR wet $_{\text {(Cahoon, }}$ 2015). The SET measurement integrates all of the processes controlling vertical soil movement within the upper $>10-23 \mathrm{~m}$ and can be used as a nearly absolute measurement of VLM $\mathrm{w}_{\mathrm{w}}$ many settings.

In addition, where subsidence is low just below the upper soil horizons (about $1 \mathrm{~m}$ deep), good correspondence can exist between radioisotopic techniques (accretion) and SET techniques $\left(\mathrm{VLM}_{\mathrm{w}}\right)$ over time. Such agreement occurred for several mangrove wetlands in south Florida; ${ }^{210} \mathrm{~Pb}$ data more often echoed SET data in determining positive values of RSLR ${ }_{\text {wet }}$ indicative of wetlands not keeping pace with sea-level rise than did vertical accretion data from marker horizons (Cahoon and Lynch, 1997). Vertical accretion measurements using marker horizon techniques often overestimate positive $\mathrm{VLM}_{\mathrm{w}}$ adjustments. Most elevation change inference from coastal swamp forests are from marker horizon or isotopic dating assessments of accretion (table 1). A combination of SETs and isotopic dating of cores can be used to evaluate the influences that a Mississippi River reintroduction into Maurepas Swamp will have on soil surface elevation.

\section{Soil Surface Elevation Performance Measure}

Preliminary $\mathrm{VLM}_{\mathrm{w}}$ data were collected by using SETs from Maurepas Swamp from 2003 to 2008 (Shaffer and others, 2016). Two applicable treatments were considered: control and fertilizer. A difficulty in conducting sedimentation and surface elevation change studies in coastal swamp forests relates to determining the actual soil surface during measurements and standardizing measurements at this soil surface over repetitive measurement cycles. Soils are often loose when flooded, so it is easier to time measurements during dewatering events (for example, winter frontal passage or drought). Such events themselves can create bias, as sites can lose elevation slightly at lower hydrologic stages (Whelan and others, 2005). With this caveat in mind, VLM from moderately healthy swamp forest control sites in more optimal streamside settings of Maurepas Swamp averaged $8.1 \mathrm{~mm} / \mathrm{yr}$, which did not differ from fertilized plots $(7.8 \mathrm{~mm} / \mathrm{yr})$ (Shaffer and others, 2016). Fertilizer treatments were designed to mimic nutrient loading from the proposed Mississippi River reintroduction described herein. In comparison to the $\mathrm{VLM}_{\mathrm{w}}$ data reported in Shaffer and others (2016), nine CRMS stations documented relevant $\mathrm{VLM}_{\mathrm{w}}$ conditions in Maurepas Swamp from 2010 to 2016 and revealed that VLM $_{\mathrm{w}}$ ranged from $-1.1 \mathrm{~mm} / \mathrm{yr}(2.3 \mathrm{~mm} / \mathrm{yr}$ standard error, CRMS0047) to $8.5 \mathrm{~mm} / \mathrm{yr}(4.7 \mathrm{~mm} / \mathrm{yr}$ standard error, CRMS5167) (table 2). All nine CRMS stations represented different habitat types and occupied different distances from moving water, such that wetland position along levees and relative to forest condition was critical in determining $\mathrm{VLM}_{\mathrm{w}}$ trends. Maximum recorded VLM $\mathrm{w}_{\mathrm{w}}$ from both efforts (that is, Shaffer and others, 2016 and the CRMS stations) was $8-9 \mathrm{~mm} / \mathrm{yr}$.

The nearest long-term, fully reliable tide gage to Maurepas Swamp is the National Oceanic and Atmospheric Administration (NOAA) gage located at Grand Isle, Louisiana (https://tidesandcurrents.noaa.gov/stationhome. html?id=8761724), approximately 120 kilometers away, but 
Table 2. Trends and notes for vertical land motion of the wetland soil surface from 2010 to 2016 at nine Coastwide Reference Monitoring System (CRMS) stations located in the Maurepas Swamp, Louisiana, project area derived from surface elevation tables having fairly continuous records.

$\left[\mathrm{VLM}_{\mathrm{w}}\right.$, vertical land motion of wetland; mm/yr, millimeter per year; \pm , plus or minus; SE, standard error of the mean; km, kilometer]

\begin{tabular}{|c|c|c|c|}
\hline Station & Location & $\begin{array}{l}\mathrm{VLM}_{\mathrm{w}^{\prime}} \\
\mathrm{mm} / \mathrm{yr} \pm \mathrm{SE}\end{array}$ & Notes \\
\hline CRMS0038 & Edge & $3.3 \pm 1.6$ & $\begin{array}{l}\text { Just off Blind River on edge of small dead-end bayou; } \\
\text { relict forest }\end{array}$ \\
\hline CRMS0047 & Edge & $-1.1 \pm 2.3$ & Edge of canal spoil bank (oilfield); relict forest \\
\hline CRMS0059 & Backswamp & $-0.3 \pm 2.8$ & $\begin{array}{l}\text { Near upland-wetland transition about } 0.8 \mathrm{~km} \text { from nearest } \\
\text { water body; sustainable forest }\end{array}$ \\
\hline CRMS0097 & Edge & $-0.9 \pm 3.0$ & Edge of canal spoil bank (oilfield); sustainable/relict forest \\
\hline CRMS5167 & Edge & $8.5 \pm 4.7$ & Canal edge running into Blind River; sustainable forest \\
\hline CRMS5255 & Edge & $6.5 \pm 2.2$ & Edge of natural levee on large high-flow bayou; relict forest \\
\hline CRMS5414 & Backswamp & $4.0 \pm 1.8$ & $\begin{array}{l}\text { Very interior site on edge of small dead end bayou; } \\
\text { sustainable/relict forest }\end{array}$ \\
\hline
\end{tabular}

this gage may be reflective of relevant deltaic conditions. That gage registered a RSLR trend of $9.07 \mathrm{~mm} / \mathrm{yr}(0.47 \mathrm{~mm} / \mathrm{yr}$, 95-percent confidence interval) over the past 60-plus years (NOAA, 2015). Based on this trend, over the 5-year period of SET measurement at Maurepas Swamp, RSLR ${ }_{\text {wet }}$ was $0.97-1.27 \mathrm{~mm} / \mathrm{yr}$ for control and fertilizer plots, respectively, equating to slight surface elevation deficits. On the other hand, RSLR $_{\text {wet }}$ data from nine CRMS stations in Maurepas Swamp (table 2) ranged from 0.58 to $10.17 \mathrm{~mm} / \mathrm{yr}$, suggesting that surface elevation deficits can be very high under current Maurepas Swamp conditions. The maximum standard deviation around the $7.8-8.1 \mathrm{~mm} / \mathrm{yr}$ surface elevation change reported in Shaffer and others (2016) was $3.1 \mathrm{~mm} / \mathrm{yr}$. These VLM $\mathrm{w}_{\mathrm{w}}$ data provide reasonable targets because these data were taken from moderately healthy swamp forests specifically located in Maurepas Swamp. Thus, among an RSLR trend of $9.07 \mathrm{~mm} / \mathrm{yr}$, a surface elevation trend for healthy Maurepas Swamp forests of 7.8-8.1 mm/yr, and the measures of dispersion around these means, we are establishing a VLM $\mathrm{w}_{\mathrm{w}}$ threshold of $8-9 \mathrm{~mm} / \mathrm{yr}$ as a mean performance measure for the Mississippi River reintroduction into Maurepas Swamp. Anything greater than $8.0 \mathrm{~mm} / \mathrm{yr}$ is considered preferred, while anything less than $4.9 \mathrm{~mm} / \mathrm{yr}$ would be unacceptable (fig. 7). This performance measure would ensure that closed forest canopy, transitional forest, and open canopy wetland are just keeping up with sea-level rise $\left(\operatorname{RSLR}_{\text {wet }}=0\right)$ or undergoing only slight deficits by building elevations vertically after the river reintroduction. This criterion will also indicate on the basis of long-term accretion records (4.3-6.3 mm/yr, table 1, with one exception, $14.0 \mathrm{~mm} / \mathrm{yr}$; Day and others, 2012) that forests in Maurepas Swamp are generally faring better after the river reintroduction than are submerging swamp forests not currently receiving river waters.

\section{Considerations}

While we have established a surface elevation change threshold of $8-9 \mathrm{~mm} / \mathrm{yr}$ for rating restoration success based on river reintroduction influences on $\mathrm{VLM}_{\mathrm{w}}$, postdiversion data collection activities may cause slight modifications of this standard over time. Inactive deltas under the influence of rising sea levels can adjust surface elevation through belowground productivity in the absence of large sediment deposits; however, we do not fully expect all of the wetland forests in Maurepas Swamp to keep up with RSLR. Important adjustments may be associated with the different trajectories of $\mathrm{VLM}_{\mathrm{w}}$ for closed forest canopy, transitional forest, and open canopy wetland sites (marsh). We establish a single metric herein based upon SET data from Maurepas Swamp and informed by data on short-term and long-term vertical accretion from additional Louisiana coastal swamp forests (table 1).

Maurepas Swamp forests have been disconnected from their natural Mississippi River conveyance for more than 190 years. Because of the nature and goals of a river reintroduction (or freshwater diversion) from the Mississippi River, versus a sediment diversion, we do not consider net antecedent surface elevation deficits that have accrued in the swamp forests when establishing the VLM $\mathrm{w}_{\mathrm{w}}$ performance standard. We do not expect the river reintroduction to compensate for that long-term deficit. Swamp forests have already responded to that deficit, and the river reintroduction should maintain the system at or in exceedance of its current elevation. That said, radioisotope dating of cores will provide insights into antecedent elevation deficits. Neither radioisotopic techniques nor SET data measure deep subsidence directly (that is, what Cahoon, 2015, terms VLM , or vertical land motion below the base of the SET and tide gage bench mark rods). 


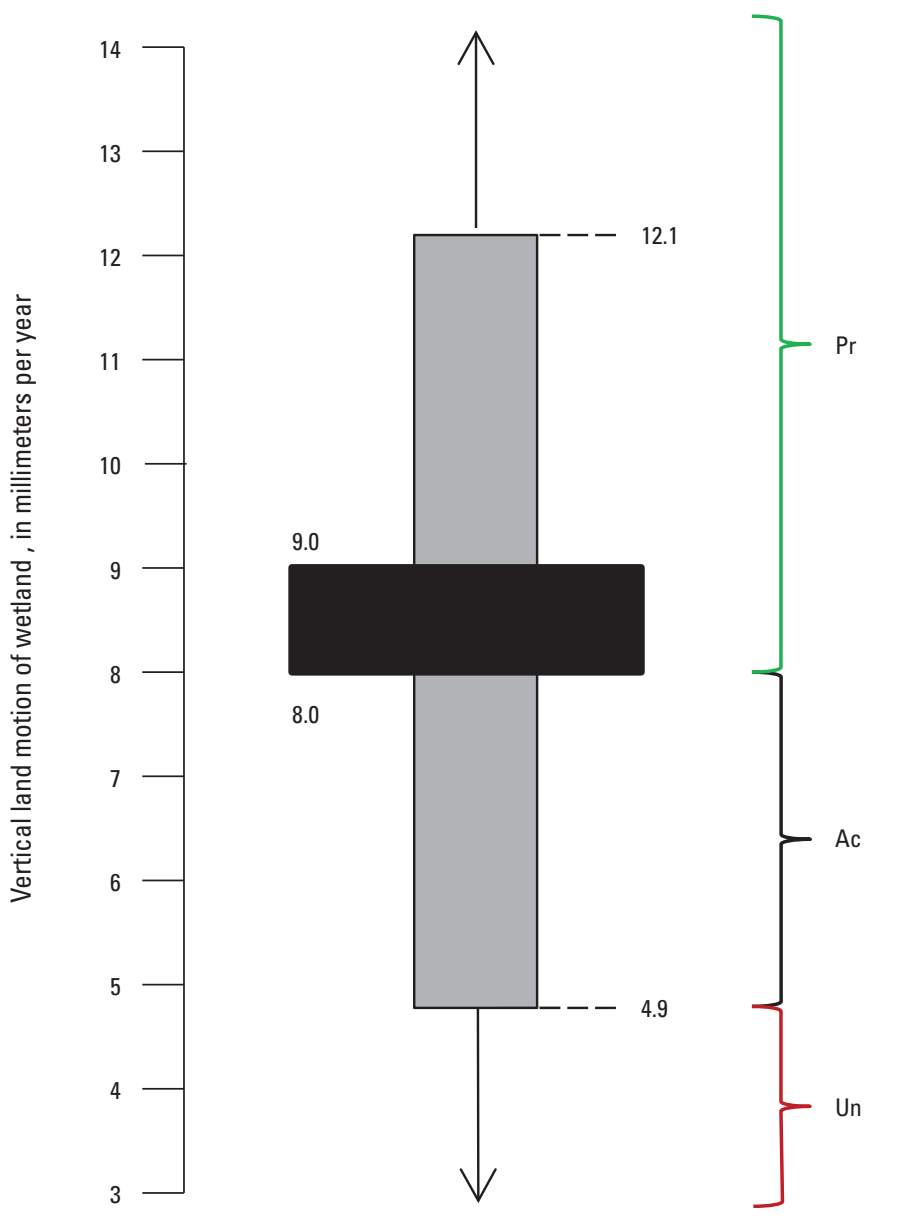

EXPLANATION

Target value range for performance measure (PM) - A single value or range of values; established by the literature

Standard deviation (or range) in measurement of mean target PM value-Based on available data

\footnotetext{
--- Actual value that represents \pm 1 standard deviation of the mean

$\mathrm{Pr} \quad$ Preferred-Values within mean target PM. This range will not trigger management action

Ac Acceptable - Values within standard deviation of measurement for target PM. This range may trigger management action

Un Unacceptable - Values outside mean target PM threshold and standard deviation of measurement for target PM. This range should trigger management action
}

Figure 7. Acceptability ranges around a target of 8-9 millimeters per year $(\mathrm{mm} / \mathrm{yr})$ for vertical land motion of the wetland $\left(\mathrm{VLM}_{\mathrm{w}}\right)$, or wetland soil surface elevation change, of coastal swamp forests impacted by a Mississippi River reintroduction into Maurepas Swamp, Louisiana. VLM ${ }_{w}$ ranges are associated with maximum standard deviations ( $3.1 \mathrm{~mm} / \mathrm{yr}$ ) recorded from preliminary surface elevation table studies in moderately healthy forests, plus a compounded error term of $0.5 \mathrm{~mm} / \mathrm{yr}$ that is included to represent the 95-percent confidence interval for relative sealevel rise data from the National Oceanic and Atmospheric Administration (NOAA) tide gage at Grand Isle, Louisiana (https:// tidesandcurrents.noaa.gov/stationhome.html?id=8761724).
The Mississippi River reintroduction into Maurepas Swamp is designed with a sediment (sand) catchment basin at the inflow from the river. There may be a potential to utilize some of this sediment beneficially in the project area to enhance sediment loading to specific sites in Maurepas Swamp, either through direct placement or dredge splay, and this sediment might be considered as part of the OMMAM, if feasible. Dredge splay operations are effective in restoring salt marsh surface elevations in pulses (Stagg and Mendelssohn, 2010), but application is less certain for coastal swamp forest rejuvenation in southeastern Louisiana (Middleton and Jiang, 2013). SET data collected from Maurepas Swamp (Shaffer and others, 2016) suggest that VLM $_{w}$ can be as high as $13.4 \mathrm{~mm} /$ yr when sediment and nutrients are added in pulses simultaneously, creating an elevation surplus $\left(\operatorname{RSLR}_{\text {wet }}=-4.3 \mathrm{~mm} / \mathrm{yr}\right.$ ). The inference around these data is weak spatially and needs to be augmented considerably during postdiversion monitoring. Furthermore, pulses of dredged material have the potential to affect the forested wetland community through plant species shifts (for example, baldcypress to Acer rubrum var. drummondii [swamp red maple] and Salix nigra [black willow]; Middleton and Jiang, 2013), which will need to be considered.

\section{Assessment Methods}

To assess the influence of a Mississippi River reintroduction into Maurepas Swamp on VLM, it is important that measurements be distributed throughout the receiving basin of the river reintroduction to include closed forest canopy, transitional forest, and open canopy wetland. Assessments of $\mathrm{VLM}_{\mathrm{w}}$ would benefit most if conducted at intervals beginning as soon as possible and spanning 50 years postdiversion. We hypothesize that VLM $\mathrm{V}_{\mathrm{w}}$ of closed forest canopy, transitional forest, and open canopy wetland will be maintained within the bounds of the established performance measure after the river reintroduction into Maurepas Swamp becomes operational. Three primary techniques may be used to assess performance associated with $\mathrm{VLM}_{\mathrm{w}}$ : (1) radioisotope dating of cores, (2) rod SETs, and (3) repetitive surveys of rod SETs using high-precision differential Real-Time Kinematic GPS (d/RTK-GPS) and continuous GPS (cGPS). For monitoring purposes, a minimum of 10 sites could be selected in each of the three habitat types (30 sites total) and distributed to reflect distance from the river reintroduction outfall into Maurepas Swamp.

A difficulty that will arise in using $\mathrm{VLM}_{w}$ in Maurepas Swamp is that installation of SETs will likely be biased toward areas that have a discernible soil surface over long periods of time. Thus, random assignment of SETs among habitat types will not likely be feasible. The wetlands of Maurepas Swamp have a number of different types of soil surfaces, ranging from highly organic layers suspended in permanently standing water to thin mats of vegetation floating on top of the permanently standing water (floating thin-mat marshes; Carpenter and others, 2007) to periodically exposed soils of mixed mineral and organic composition. By necessity, assessments will err toward periodically exposed soils throughout the basin; SET measurements and radioisotope coring are not feasible in floating 
thin-mat settings. Considerable effort must be made, however, to ensure that radioisotope core extraction and deployments of SETs are within habitats as indicative of all Maurepas Swamp habitats as possible; for example, ensure that streamside locations or areas near levees are not selected simply because they are easier to access.

\section{Radioisotope Dating of Cores}

Three replicate cores can be collected from each of the 30 sites (or a statistically valid subset of these sites) by using either a thin-walled aluminum coring tube 15 centimeters (cm) in diameter (Rybczyk and others, 2002) or a 15-cmdiameter Hargis corer (Hargis and Twilley, 1994), depending on the consistency of the soils, to minimize compaction. Cores are sampled to a depth of at least $70 \mathrm{~cm}$, capped in the field, and kept vertical until processed. In the laboratory, cores are sectioned into a maximum of $2-\mathrm{cm}$ increments, wet weighed, dried to a constant weight at 60 degrees Celsius, and reweighed. Dry bulk density (in grams per cubic centimeter $\left[\mathrm{g} / \mathrm{cm}^{3}\right]$ ) of soils is determined for each section and ground to pass through a 2-mm sieve, where each soil section can be analyzed for total carbon $(\mathrm{C}$, in percent), total nitrogen $(\mathrm{N}$, in percent), and total $\mathrm{P}$ (in percent). Subsections of cores are then analyzed for ${ }^{210} \mathrm{~Pb}$, radium-226 $\left({ }^{226} \mathrm{Ra}\right)$, and ${ }^{137} \mathrm{Cs}$ to assign dates to specific depths by using techniques described previously (Lynch and others, 1989; Drexler and others, 2013). Cores can be extracted initially, at the beginning of river reintroduction influence, and then at a minimum of 5, 10, 20, and 50 years postdiversion.

\section{Rod SETs}

The installation of three replicate rod SETs (Cahoon and others, 2002) would be beneficial if deployed on each of the 30 sites in Maurepas Swamp (90 rod SETs total). Rod SETs must be installed to National Geodetic Survey (NGS) standards, equating to acceptable refusal standards for Class B rod marks (Floyd, 1978). Previous deployments of rod SETs in Maurepas Swamp and surrounding marshes indicate a fairly consistent depth to refusal of $14.3 \mathrm{~m}( \pm 1.1 \mathrm{~m}$ standard error) for the CRMS stations and $15.9 \mathrm{~m}( \pm 2.4 \mathrm{~m}$ standard error $)$ for rod SETs installed by Shaffer and others (2016).

Each rod SET will serve as an independent survey bench mark, and VLM ${ }_{w}$ will be measured relative to that insertion depth (fig. 8). Shallow subsidence will be defined as those processes occurring within the top 14.3-15.9 m of soil (if previous installations are consulted). Each rod SET is paired initially with marker horizons (MH; Cahoon and others, 1999) made of feldspar clay or other marker horizon types (for example, plastic netting) to track vertical accretion to relate with rod SET measurements. It should be noted that previous attempts to use feldspar in Maurepas Swamp were not successful, so some experimentation with other techniques may be necessary to identify this component of VLM $\mathrm{w}_{\mathrm{w}}$. Together, the rod SET-MH approach allows for determinations of $\mathrm{VLM}_{\mathrm{w}}$, vertical accretion, shallow subsidence, and (or) root zone expansion. Also, of particular importance in Maurepas Swamp is ensuring that enough time passes (5-10 years) for the $\mathrm{VLM}_{\mathrm{w}}$ signal to overcome the noise in the data. Because

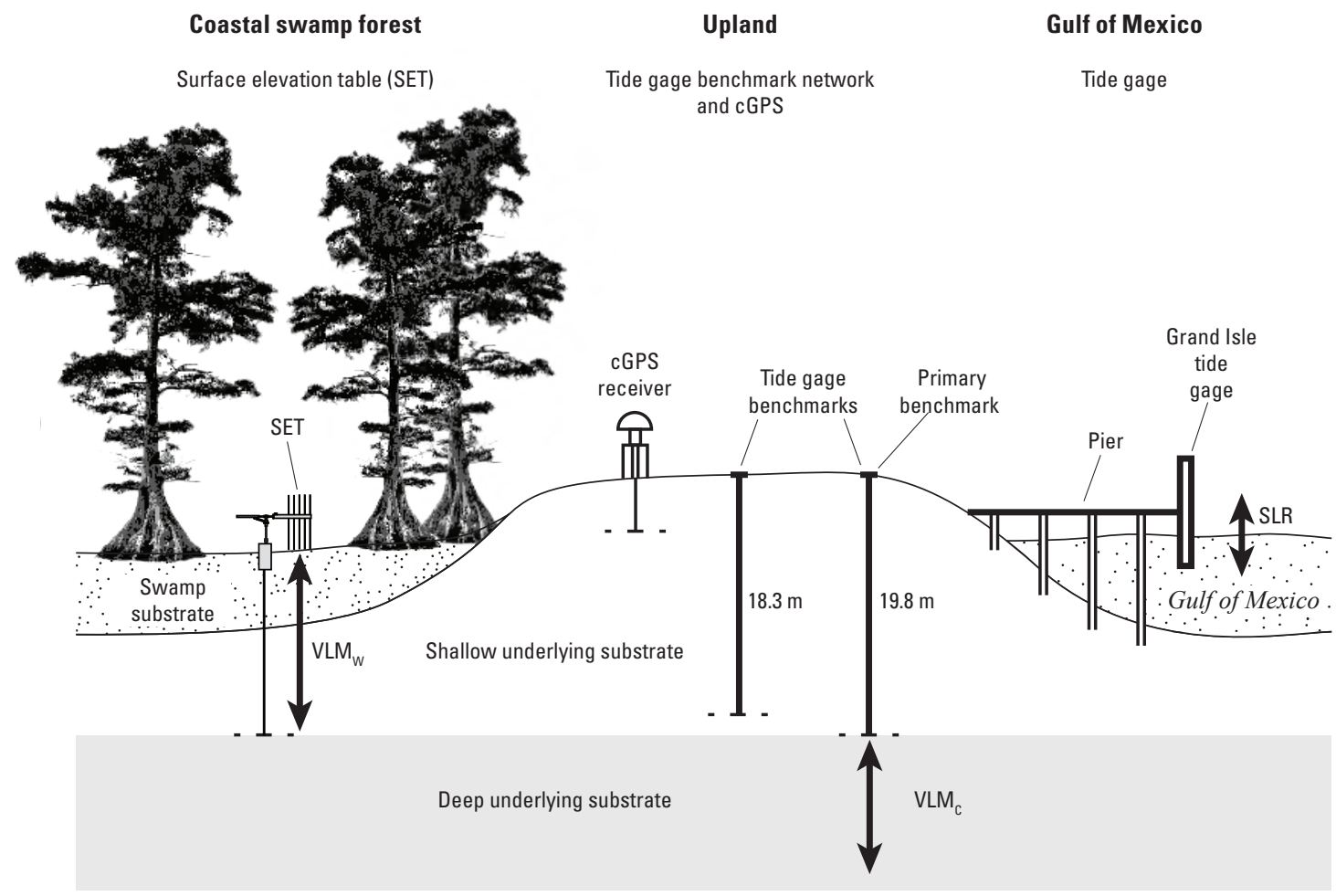

Figure 8. Components of vertical land motion of the wetland VLM $_{w^{\prime}}$, wetland surface elevation change) for Maurepas Swamp, Louisiana, relative to the tide gage characteristics of the National Oceanic and Atmospheric Administration (NOAA) tide gage at Grand Isle, Louisiana (artwork courtesy of James C. Lynch, National Park Service). cGPS, continuous Global Positioning System; SLR, sea-level rise. 
the tide gage at Grand Isle is surveyed repetitively against terrestrial bench marks inserted to $18.3 \mathrm{~m}$ (NOAA datum $1724 \mathrm{~A}$ 1980) and 19.8 m (NOAA datum 1724 B 1980) (see benchmark sheet at https://tidesandcurrents.noaa.gov/benchmarks. html?id=8761724) (fig. 8), RSLR ${ }_{\text {wet }}$ determinations from each rod SET will be accurate and encompass similar horizontal soil profiles. Some attempt may also be made to relate VLM readings to tide gages that are closer to Maurepas Swamp than Grand Isle (for example, the 33-year record from the NOAA gage at New Canal, Lake Pontchartrain, Louisiana, or other gages maintained by the U.S. Army Corps of Engineers) whenever possible, keeping in mind that standards for gages may deviate from those of NOAA but that gages closer to Maurepas Swamp will reflect more appropriate rates of VLM (see section "Repetitive Surveying of SETs by Using HighPrecision d/RTK-GPS and cGPS"). Continued measurement of existing SETs, including 12 on the land bridge between Lakes Maurepas and Pontchartrain and 11 at CRMS stations in the swamp forest (previously referenced, with 9 having currently acceptable $\mathrm{VLM}_{\mathrm{w}}$ trends, table 2), would greatly augment PM3 assessment.

\section{Repetitive Surveying of SETs by Using High-Precision d/ RTK-GPS and cGPS}

Another component of submergence potential determinations for Maurepas Swamp includes accounting for deep subsidence occurring below the rod SET and tide gage bench mark depths. Cahoon (2015) defined another term, VLM ${ }_{c}$, that describes "the velocity of the substratum at the base of the [tide gage bench mark]"; for Maurepas Swamp, the proposed tide gage bench mark is the Grand Isle gage (fig. 8). Recent $\mathrm{VLM}_{\mathrm{c}}$ (since 1965) has been variously defined in coastal Louisiana as ranging from 5.3-10.8 mm/yr (Penland and others, 1988) to $8-12 \mathrm{~mm} / \mathrm{yr}$ (Morton and others, 2005), at least from wetland areas south of Maurepas Swamp. Of importance, historical rates of $\mathrm{VLM}_{\mathrm{c}}$ from the previous 5,000 years were lower from these same areas $(1-5 \mathrm{~mm} / \mathrm{yr}$, Morton and others, 2005). If a similar rate of VLM $_{c}$ increase has occurred in Maurepas Swamp, then submergence potential might be insurmountable despite what is tracked as a performance measure associated with $\mathrm{VLM}_{\mathrm{w}}$. Because deep subsidence $\left(\mathrm{VLM}_{\mathrm{c}}\right)$ can vastly affect determinations of RSLR ${ }_{\text {wet }}$, repetitive d/RTK-GPS and cGPS surveys provide a critical tool for tracking the movement of individual SET bench marks to establish VLM records for each SET. Surveys conducted immediately or soon after the first rod SET readings are made would be most beneficial and then at intervals of every 2 years thereafter for at least 10 years. Subsequent surveys can be conducted with less frequency, but at intervals of no less than 5-10 years for the duration of river reintroduction monitoring. The accuracy of d/RTK-GPS assessments can be coarse (20-60 mm, Renschler and others, 2002), but when paired with continuous GPS (cGPS) readings to include deployment for periods of at least 3-4 days, accuracy can be greatly improved $( \pm 4-6 \mathrm{~mm})$.

\section{PM4: Increasing Forest Structural Integrity}

The concept of forest sustainability is based on the idea that disturbance does not fundamentally and irreversibly alter the autogenic successional pathway of forests (Kimmins, 1995). In a sustainable forest, disturbances alter the structure and species composition of the forest, but do not change it permanently to a different forest type or away from forest altogether. In forested wetlands, disturbances are both episodic and chronic, but the defining feature is flooding. Flooding is a stress for most woody species, and, while it also subsidizes the growth of plants, the tension between the stressors and subsidies determines the structure of the ecosystem (Odum and others, 1979). Thus, change in the flood regime is the most common cause of change in structural attributes of forested wetlands.

Flooding effects are not constant in time or space, so forested wetlands are not static communities. In some cases, particularly baldcypress-water tupelo forests, individual trees are so long-lived and resilient to varying conditions that they can span large changes in growing conditions (Wilhite and Toliver, 1990). Even though large trees do respond to large disturbances, their responses to less intense change are not necessarily useful indicators of smaller but important changes in growing condition. It is difficult to monitor forest sustainability by using large trees because small changes that would modify the response of the forest to disturbance may not be evident until the disturbance occurs (for example, Battaglia and others, 1999). Therefore, a vegetation monitoring plan for forest structure requires using both overstory trees and other vegetation (Wood and others, 2017).

\section{Performance Measure Discussion and Literature}

One key variable to monitor for forested wetland sustainability is mortality of overstory trees. As forests grow, stand development leads to competition among forest trees. This competition causes suppression and eventual mortality of lesscompetitive individuals while neighboring individuals grow to occupy the available space. Thus, the number of individuals that can occupy a site depends on their size (Curtis, 1970; Long and Smith, 1984). The relation between tree size and density at which trees compete with each other is relatively predictable depending on species (Dean and Baldwin, 1996), so the sizes and number of trees can be measured to determine whether forest trees are competing with each other or if densities are too low for inter-tree competition to be important. Stand development of forested wetlands is similar to that of other forests (Keim and others, 2013a) in that density-dependent mortality occurs in response to forest growth.

Allogenic forces (that is, not from competition with other trees), such as flooding and salinity intrusion, can also cause mortality. Thus, stand densities below those expected for forests undergoing normal autogenic competition (that is, below the threshold of full site occupancy) can be interpreted as the result of disturbance. In those stands, regeneration is 
expected because of high resource availability, but continued lack of regeneration is an indicator of disturbance processes (especially flooding in Maurepas Swamp) that are too severe for sustained forest occupancy. Lack of regeneration is not the primary indicator of nonsustainability when forest densities are high because seedlings of most species (such as baldcypress and water tupelo) require light to thrive (Wilhite and Toliver, 1990; Johnson, 1990).

Another metric of forest productivity is leaf area index (LAI; one-sided leaf area per unit ground area), which is a measure of the photosynthetic capacity of a forest (Waring and Running, 2010). The LAI is related to stand density, though there is some independence between the two. In particular, LAI can be an effective way to measure premortality loss of forest vigor because tree crowns generally decline prior to death (Kozlowski, 1984). In baldcypress-water tupelo wetlands, Allen and others (2015) found leaf area to be lower where flooding is deeper, but it can be difficult to determine whether low leaf area is caused by lack of regeneration or lowvigor growth in the absence of insect or other damage.

Because tree densities, existing tree regeneration, and canopy density are not complete and reliable indicators of sustainable growing conditions, subtle changes in vegetation composition can be tracked through the use of various indices, such as a floristic quality index (FQI). An FQI provides a numerical measure of habitat quality based upon the species composition of plants indicative of a specific habitat in relation to species that may not represent that habitat (for example, Lopez and Fennessy, 2002; Cohen and others, 2004; Allain and others, 2006; Ervin and others, 2006). To develop an FQI, the suite of individual species present in a given habitat is independently assigned a coefficient of conservatism score, ranging from 0 to 10 . Species indicative of a specific habitat (for example, baldcypress in Maurepas Swamp) are assigned a score of 10; species less indicative of that habitat are assigned scores $<10$, ending with nonnative plants being assigned a score of 0 (table 3; forested FQI). These scores are developed by a group of experts familiar with the local flora and the habitats they typically represent (Cretini and others, 2012).
An FQI was developed for coastal Louisiana marshes and has been applied successfully to evaluating restoration success on several marsh sites (Cretini and others, 2012). As part of this effort targeting marsh habitats, a similar FQI, termed the "forested FQI" (FFQI), also was developed for coastal Louisiana swamp forests and tested against applicable datasets (Wood and others, 2017). We propose usage of the FFQI as a performance measure to document potentially small and subtle shifts in habitat quality after the river reintroduction into Maurepas Swamp becomes operational. The FFQI targets mostly overstory tree species but has been developed with embedded modifiers that respond to canopy light penetration and herbaceous plant shifts in the understory that can change from year to year (Wood and others, 2017). The formulation of the FFQI has been described in detail by Wood and others (2017), with an in-depth literature review provided in the original reports on which it is based (Cretini and others, 2011, 2012). Also, over time, successful regeneration of desired forest trees and incorporation into the midstory and overstory environments influence the FFQI positively and will serve as a strong metric of true regeneration (or impact on desired trees) as facilitated by the river reintroduction.

\section{Forest Structural Integrity Performance Measures}

We developed two performance measures associated with forest structural integrity, one targeting stand density and the other targeting the FFQI metric, as follows.

\section{Stand Density}

Densities associated with full site occupancy have been established by Putnam and others (1960) and Keim and others (2010b) in terms of Reineke's (1933) stand density index (SDI). For baldcypress, maximum SDI is 1,200 (Keim and others, 2010b); the maximum SDI for mixed baldcypress-water tupelo and pure water tupelo is likely as much as 10 percent less (Putnam and others, 1960; Shaffer and others, 2016), but the difference is small enough that they can be treated

Table 3. Ranges of coefficient of conservatism (CC) score assignment and general criteria for plants occurring in coastal forested wetlands and adjacent marsh habitat in Louisiana (from Cretini and others, 2012).

[FFQI, forested floristic quality index]

\begin{aligned} & \hline CC score \multicolumn{1}{c}{ Criteria for Louisiana swamp FFOI } \\ & \hline 0 Nonnative plant species, woody and herbaceous \\ & $1-3$ Plants that are opportunistic users of disturbed forested wetland sites \\ & $4-6$ Plants that occur primarily in less vigorous ${ }^{1}$ coastal forested wetland communities \\ & $7-8$ Plants that are common in vigorous ${ }^{1}$ coastal forested wetland communities \\ & \hline $9-10$ Plants that are dominants in vigorous ${ }^{1}$ coastal forested wetland communities \\ & \hline\end{aligned}

${ }^{1}$ As per Cretini and others (2012), "vigorous implies that a coastal wetland community is composed generally of native species and that is minimally influenced by disturbance" (p. 2391). 
the same as baldcypress. Sites with less than 30 percent of maximum SDI (SDI <360), LAI less than 2 square meters per square meter $\left(\mathrm{m}^{2} / \mathrm{m}^{2}\right.$, hereafter unitless), and no regeneration present will be considered nonsustaining (unacceptable) because they are well below the site occupancy threshold (fig. 9). Assuming a standard deviation of 0.88 for LAI in swamp forests above the site occupancy threshold (Keim and others, 2013a) and using what we know about the standard deviation surrounding SDI values from Maurepas Swamp (standard deviation of about 100 for SDI; Shaffer and others, 2016), targets are therefore established as 45 percent of maximum SDI (acceptable range, 30-45 percent) and 2.9 for LAI (acceptable range, 2.0-2.9). Stands at $>45$ percent of maximum SDI and LAI $>2.9$ are well above the site occupancy threshold and within the preferred range (fig. 9). These values are consistent with those observed by Keim and others (2013a), who found that baldcypress-water tupelo forests in transitional or open conditions typically had stand densities below the threshold at which mortality is expected from competition, indicating that stressors led to mortality and that regeneration was inhibited by flooding.

\section{FFOl}

Because of the nature of the FFQI, a performance measure associated with this index would only be applied to track anticipated change associated with the transitional forest habitat (fig. 2). Thus, for closed forest canopy, no obvious change would be anticipated since the sites may already be healthy, and for open canopy wetland, many of these areas represent healthy marsh. Nevertheless, FFQI (and FQI) assessments will be made in all habitats, but no specific performance measure will be established for the closed forest canopy or open canopy wetland condition. By definition, open canopy wetland will have to grade into transitional forest before the FFQI measure is applied quantitatively to be used as a performance measure. This transition may happen if tree regeneration is stimulated in open canopy wetland areas. FFQI change can only be rated against those healthy reference forests located within Maurepas Swamp or against prediversion FFQI values on individual sites.

Some uncertainty surrounds an appropriate target for FFQI change for Maurepas Swamp; however, while developed for Louisiana forested wetlands (Wood and others, 2017), this technique has never been applied to a specific restoration situation outside of examples used in the original manuscript (Cretini and others, 2012). Thus, gains from FQI application to coastal marshes were used for reference versus project sites (Cretini and others, 2012). For marshes, FQI scores diverged on average 12.3 points ( \pm 13.5 standard deviation) for project sites versus reference sites when applied from 2005 to 2009; this divergence tracked recovery from a hurricane for FQI scores of project versus reference sites (Cretini and others, 2012). The full range of the FFQI response is $0-100$, so 12.3 is also a percentage. Any increase of 12.3 percent or greater in FFQI between any 5-year period postdiversion for transitional forest habitat would be a strong indicator of success of the project (preferred), although any positive increase will also be acceptable (fig. 10). Any decrease in FFQI would be problematic, although the FFQI metric can be variable among plots, so measurement variation will need to be determined.

\section{Considerations}

\section{Stand Density}

One limitation to using SDI is in determining a reasonable standard deviation surrounding the targeted maximum SDI value (Ducey and Larson, 1999). SDI is a metric that defines the entire stand such that variance of the population mean would technically be zero (T.J. Dean, written commun., 2016), so any guidance on standard deviation from Maurepas Swamp provided to date (for example, Shaffer and others, 2016), can be applied with reasonable caution as an acceptability guide for the SDI performance measure. Likewise, measurements of LAI need to be taken from standardized locations representative of the canopy condition such that midstory shrub vegetation does not falsely increase repetitive LAI measurements.

In general, the ability to interpret stand density and leaf area in terms of ecological processes and sustainability is better for baldcypress than for water tupelo or other species common in Maurepas Swamp. While there are some tools available to translate baldcypress-centric measurements to water tupelo-specifically in terms of stand density as analyzed by Goelz (1995) - there has been little quantitative field testing. Water tupelo trees are common in Maurepas Swamp, and they are also subject to more intense disturbance pressure from insect defoliators (Effler and others, 2006) and breakage from tropical storms (Doyle and others, 1995) and tend to defoliate during drought (G.P. Shaffer, unpub. data, 2015). Thus, it will be important to interpret results for stands with high water tupelo composition with appropriate caution and to back up monitoring with applied research to strengthen the validity of these tools.

\section{FFOI}

Besides ensuring that the correct data are collected from sites, the largest criterion that must be addressed for the successful use of the FFQI metric is consistency in data collection among time periods. Forest basal area metrics can be straightforward to measure; however, canopy density and herbaceous plot characteristics are more difficult to standardize among field investigators. Also, established thresholds might need to be altered slightly over time as these metrics are incorporated into adaptive management. Although canopy density and herbaceous plot characteristics are weighted less than basal area, these variables are added as modifiers such that error associated with the data collection from these variables will affect results (Wood and others, 2017). In addition, the FFQI has not been applied widely to any forested wetland condition in Louisiana and should still be considered experimental. Therefore, modifications to the target standards as surmised from marsh FQI data may need to be adjusted. 


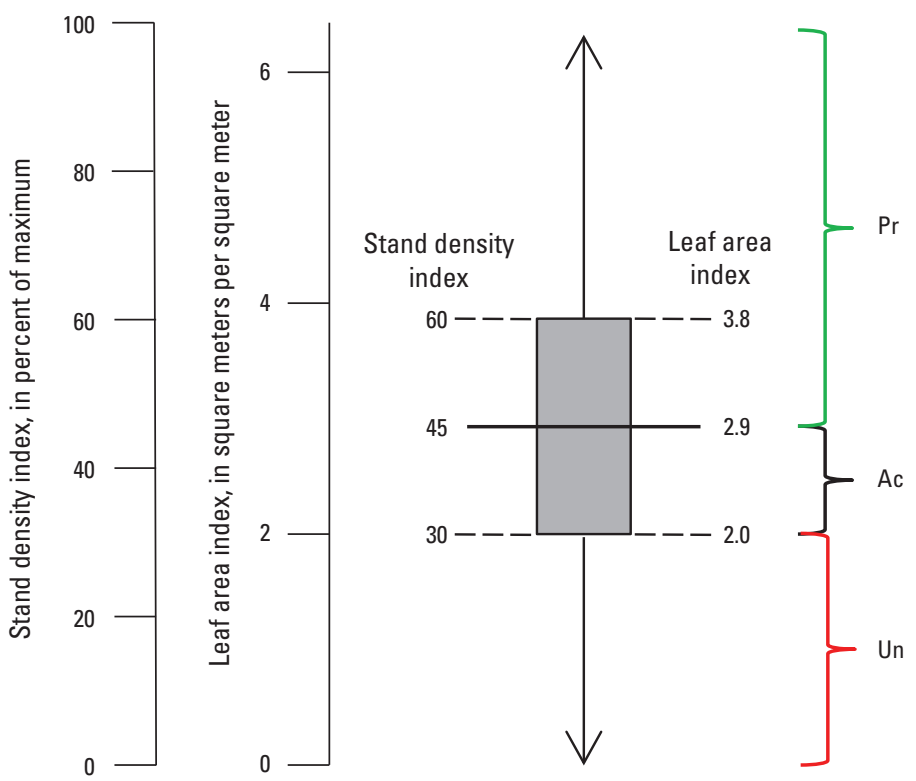

\section{EXPLANATION}

Target value for performance measure (PM) — A single value or range of values; established by the literature

Standard deviation (or range) in measurement of mean target PM value - Based on available data

--- Actual value that represents \pm 1 standard deviation of the mean

Pr Preferred-Values within mean target PM. This range will not trigger management action

Ac Acceptable - Values within standard deviation of measurement for target PM. This range may trigger management action

Un Unacceptable - Values outside mean target PM threshold and standard deviation of measurement for target PM. This range should trigger management action

Figure 9. Acceptability ranges around a 45-percent target for stand density index (SDI) and a leaf area index (LAI) of 2.9 square meters per square meter for coastal swamp forests impacted by a Mississippi River reintroduction into Maurepas Swamp, Louisiana. Sites with less than 30 percent of maximum SDI, LAI less than 2.0, and no regeneration present will be considered nonsustaining (unacceptable). Stands at greater than 45 percent of maximum SDI and LAI greater than 2.9 are well above the site occupancy threshold and within the preferred range.

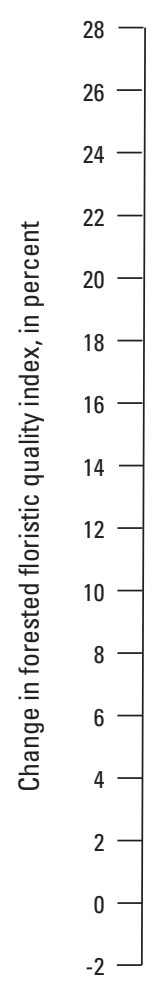

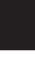

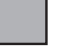
or range of values; established by the literature

Standard deviation (or range) in measurement of mean target PM value-Based on available data

\footnotetext{
$\mathrm{Pr} \quad$ Preferred — Values within mean target PM. This range will not trigger management action

Ac Acceptable-Values within standard deviation of measurement for target PM. This range may trigger management action

Un Unacceptable - Values outside mean target PM threshold and standard deviation of measurement for target PM. This range should trigger management action
}

Figure 10. Acceptability ranges (0-12.3 percent) around a 12.3-percent target for change in forested floristic quality index (FFOl) scores of coastal swamp forests impacted by a Mississippi River reintroduction into Maurepas Swamp, Louisiana. FFOI ranges are associated with average standard deviations (13.5 percent) for divergence between reference and project sites after hurricane impact recorded by Cretini and others (2012) for marshes. Performance intervals equal 5 years, although FFOl is assessed annually. 
Finally, although we are currently proposing application of this FFQI to track change in the transitional forest condition only, the FFQI (and the complementary FQI) can be measured in all three habitat types on a regular basis. Investigators need to make special note of major changes recorded in all habitat types. Rapid degradation in FFQI (or FQI) scores from any habitat type may indicate a need for an adjustment to diversion structure outflow management. Supplemental techniques, such as importance values (Curtis and McIntosh, 1950), can be applied to data already collected and used in concert with FFQI to verify shifts in dominant species composition. Importance values have been used very effectively in forested wetlands to identify subtle difference in tree species shifts (Duberstein and others, 2014).

\section{Assessment Methods}

It is important to differentiate mortality caused by stresses such as flooding from mortality caused by competition. To interpret mortality on monitoring plots, and to interpret historical mortality, measuring tree diameters and numbers of trees per unit area to determine forest stand density is conducted periodically and distributed across river reintroduction-impacted wetlands of Maurepas Swamp. In keeping with the recommendations outlined in section "PM3: Increasing Rates of Soil Surface Elevation Gain" and considering the suspected variation around measurements of stand density and FFQI, a minimum of 10 sites might be selected in each of the three habitat types (closed forest canopy, transitional forest, open canopy wetland), for a total of 30 new study sites, and distributed to reflect distance from the outflow of the river reintroduction into Maurepas Swamp. These sites are established in addition to the 24 plots already established in Maurepas Swamp and maintained by Southeastern Louisiana University (see app. 1) to incorporate historical context and can be used collectively to assess PM4 (total of 54 study plots). Additional sites may be required in the future as actual variation in stand density and FFQI from Maurepas Swamp is considered during the first 5 years of monitoring.

Measurements of LAI can be made on monitoring plots periodically by using light-extinction methods, in which leaf area is estimated by using measurements of the light environment and interpreted by using species-specific calibration of light extinction-LAI relations (Allen and others, 2015). To apply the FFQI, data collection for all of the forest structural plots can follow the protocols established by CRMS. Alterations to the specific techniques are acceptable; however, data collection must target similar forest structural, canopy density, and understory herbaceous community responses (that is, for simultaneous FQI assessment). A summary of data collection scope and frequency of CRMS is available at http://cims. coastal.la.gov/ and in associated reports (Cretini and others, 2011; Folse and others, 2014). Coefficient of conservatism scores for individual forested wetland and marsh plants have already been developed and are reported by Cretini and others (2011).
Remote sensing can also be used to leverage land-based monitoring. Image interpretation of digital orthophotography and statistical analysis of multispectral satellite data can delineate forest extent and species composition periodically, even though no performance measure is being established specifically to track areal change. Methods of Huguenin and others (1997), who developed methods to distinguish species composition between baldcypress and water tupelo, and Keim and others (2013b), who developed methods to delineate forest stand density and aquatic plant communities, or similar techniques, may be used. Specific satellite data to be used should remain flexible into the future of the monitoring effort because of rapidly evolving technology.

\section{PM5: Facilitating Nutrient Uptake and Retention}

Waters of Lake Maurepas have low levels of dissolved inorganic $\mathrm{N}$ (that is, nitrate or nitrite $\left[\mathrm{NO}_{\mathrm{x}}\right]$ and ammonium $\left[\mathrm{NH}_{4}^{+}\right]$), about 100 times less than $\mathrm{N}$ concentrations in the Mississippi River (Lane and others, 2003). Fertilizer studies have demonstrated increased rates of growth of both baldcypress (Myers and others, 1995; Beville, 2002; Lundberg, 2008; Lundberg and others, 2011; Shaffer and others, 2015) and herbaceous vegetation (Shaffer and others, 2009a) in coastal Louisiana swamp forest environments. Thus, it is likely that a Mississippi River reintroduction into Maurepas Swamp will stimulate aboveground and belowground net primary productivity (NPP), the extent of which depends largely upon the rate of nutrient loading, degree of nutrient uptake, and rate of denitrification.

Studies relating nutrient loading from river reintroductions to swamp forest success in coastal Louisiana are rare (Lundberg and others, 2011), although benefit to interannual aboveground productivity from a greater supply of freshwater from a river reintroduction has been suggested previously (Middleton and others, 2015). For brackish marsh, Graham and Mendelssohn (2014) identified an apparent compensatory effect of nutrient enrichment on accretionary processes whereby shallow subsidence, attributed to reduced live root standing crop, was balanced by enhanced accretion resulting from greater organic matter accumulation at the soil surface. $\mathrm{N}$ and $\mathrm{P}$ have been applied to the Great Sippewissett salt marsh in Massachusetts since the early 1970s, with total N loading rates ranging from 18 grams $(\mathrm{g})$ of $\mathrm{N}$ per square meter per year $\left(\mathrm{g} \mathrm{N} \mathrm{m}^{-2} \mathrm{yr}^{-1}\right)$ to greater than $157 \mathrm{~g} \mathrm{~N} \mathrm{~m}^{-2} \mathrm{yr}^{-1}$, with no major wetland deterioration (Valiela and others, 1976; Giblin and others, 1980, 1986; Turner and others, 2009; Fox and others, 2012). Turner and others (2009) did report a reduction of belowground biomass; however, the Sippewissett salt marsh remains intact after more than 35 years of nutrient additions. Fox and others (2012) suggested that the accretion reduction might be overstated because of solubility of ash. Anisfeld and Hill (2012) carried out a 5-year study of fertilization on a Connecticut salt marsh. They concluded that neither N nor P fertilization led to elevation loss, reduced soil C, or a decrease in belowground primary production. 
Shorter term nutrient additions to Louisiana salt marshes that resulted in reduced belowground biomass and soil strength had loading rates more than an order of magnitude higher $\left(225 \mathrm{~g} \mathrm{~N} \mathrm{~m}^{-2} \mathrm{yr}^{-1}\right)$ than loading rates from current freshwater reintroductions or assimilation wetlands in Louisiana (Darby and Turner, 2008a, b, c; Turner, 2010). Moreover, the fertilizer that Darby and Turner (2008a, b, c) used contained $425 \mathrm{~g}$ of sulfur (S) per $\mathrm{m}^{2}$ (Nyman, 2014), and in wetlands $\mathrm{S}$ rapidly reduces to toxic sulfides. Finally, Morris and others $(2013 \mathrm{a}, \mathrm{b})$ found that 8 years of fertilization in a Spartina alterniflora (smooth cordgrass) salt marsh in North Inlet, South Carolina, caused higher aboveground biomass, which resulted in more friction that in turn caused mineral sediment to fall out of the water column and resulted in increased elevations compared to the control marsh. A review of the literature indicates that a greater number of studies show positive impacts of added nutrients on marshes (Haines and Dunn, 1976; Valiela and others, 1976; Buresh and others, 1980; Haines, 1979; Stevenson and Day, 1996; Shipley and Meziane, 2002; Day and others, 2004, 2006; Ravit and others, 2007; Hunter and others, 2009a, b; Carrell, 2009; Shaffer and others, 2009a; Hillmann, 2011; Priest, 2011; Zhang and others, 2013; Morris and others, 2013a) than negative impacts (Morris and Bradley, 1999; Darby and Turner, 2008a, b, c; Swarzenski and others, 2008; Wigand and others, 2009; Deegan and others, 2012), but nutrient loading from a river reintroduction to a coastal swamp forest remains untested.

The Atchafalaya River and Wax Lake Deltas have developed with very high river input, and the region affected by Atchafalaya River input has low wetland loss rates compared to most of the Louisiana coastal zone (Britsch and Dunbar, 1993; Barras and others, 2008; Couvillion and others, 2011). Day and others (2011a) reported that salt marshes near lower Fourleague Bay with strong riverine input have been stable for more than half of a century, whereas salt marshes east of Bayou Terrebonne, with no river influence, have high rates of deterioration. Neither of these sites has significant hydrologic alteration otherwise. Day and others (2011b) reported similar findings for the region of the northwestern Mediterranean Sea, where coastal marshes with riverine input had much higher rates of vertical accretion, elevation gain, and belowground biomass and were likely to survive accelerated sea-level rise. Even in the Po River Delta, Italy, which has $\mathrm{NO}_{3}{ }^{-}$concentrations of only 10 milligrams per liter $(\mathrm{mg} / \mathrm{L})$ and little suspended sediments, accretion at the river mouth sites was three to four times higher than at sites that were not riverine influenced (Day and others, 2011b).

In contrast to these previous findings, Izdepski and others (2009) reported that discharge of treated sewage effluent into a shallow open water area near Thibodaux, Louisiana, led to the formation of a freshwater floating marsh, and Swarzenski and others (2008) reported that floating Panicum hemitomon (maidencane) marshes in the Bayou Penchant region affected by inflow of the Atchafalaya River were in a state of deterioration with the organic matter substrate more decomposed and with higher concentration of $\mathrm{S}$ than areas that did not receive river water. Swarzenski and other (2008) concluded that the continual input of river water leads to a reducing soil environment, increased sulfide and inorganic nutrients in pore water, and internally generated alkalinity and that these conditions can lead to organic matter decomposition and root decomposition for this marsh type.

\section{Performance Measure Discussion and Literature}

Hunter and others (2015) found that an assimilation wetland in Mandeville, also located in the Lake Pontchartrain Basin of coastal Louisiana, had average total $\mathrm{N}$ and total $\mathrm{P}$ loading rates of 56.5 and $13.9 \mathrm{~g} \mathrm{~m}^{-2} \mathrm{yr}^{-1}$, respectively, from 2006 to 2013, which resulted in average swamp aboveground NPP of 1,250 $\mathrm{g} \mathrm{m}^{-2} \mathrm{yr}^{-1}$. Shaffer and others (2015) found that baldcypress seedling aboveground production in an assimilation wetland was greatest at the outfall pipe and followed a linear decrease to $700 \mathrm{~m}$ from discharge, as did nutrient concentration. A river reintroduction into Maurepas Swamp will deliver far fewer nutrients overall, so assimilation projects would not be appropriate surrogates. There have, however, been numerous studies showing either increased growth or no effect on baldcypress exposed to nutrified water. Keim and others (2012) found that nutrient increases were not sufficient to prevent forest degradation from increasing water level. Effler and others (2006) found increased growth rates for forested wetland trees in Maurepas Swamp for trees that were given nutrient amendments. Similar growth increases also have been reported for other wetlands (Brown, 1981; Conner and others, 1981). Hunter and others (2009a) found slightly higher, but not significant, baldcypress growth at an assimilation wetland in Breaux Bridge, Louisiana. Total NPP was also highest at the treatment sites of an assimilation wetland for the town of Amelia, Louisiana (Day and others, 2006). Finally, Hillmann (2011) found a linear increase in aboveground and belowground NPP in baldcypress and water tupelo for loading rates ranging from 0 to $100 \mathrm{~g} \mathrm{~N} \mathrm{~m}^{-2} \mathrm{yr}^{-1}$. An elevation surplus occurred when nutrient addition was combined with sediment addition (Shaffer and others, 2016), suggesting that sites most proximal to a river reintroduction may receive the greatest benefits from nutrient loading.

\section{Nutrient Uptake and Retention Performance Measure}

Assessing N loading into Maurepas Swamp is of great importance since evidence suggests that these wetlands can benefit from more $\mathrm{N}$, but that excessive loading of $\mathrm{N}$ can cause elevation losses in some cases and eutrophication in downstream lakes and streams. This performance measure is being established to ensure that most $\mathrm{NO}_{3}{ }^{-}$from the Mississippi River reintroduction into Maurepas Swamp is taken up by the swamp and does not contribute to eutrophication downstream. To estimate reasonable $\mathrm{NO}_{3}{ }^{-}$loading rates from the river reintroduction, a modeling effort for the project was bounded 
on the north by Lake Maurepas, the west by Blind River, the south by U.S. Highway 61 (Airline Highway), and the east by U.S. Interstate 55, creating a 16,583-ha project area. For this simulation, on average the river reintroduction would operate at $42 \mathrm{~m}^{3} / \mathrm{s}$ (about 1,500 $\mathrm{ft}^{3} / \mathrm{s}$ ) in keeping with the capacity of the conveyance canal, and the value used for concentration of $\mathrm{NO}_{3}^{-}$is the same as in river water, or $1.5 \mathrm{mg} \mathrm{NO}_{3}^{-} / \mathrm{L}$ (Day and others, 2004). The standard deviation around this mean is $0.556 \mathrm{mg} \mathrm{NO}_{3}^{-} / \mathrm{L}$ (based on a 20-year dataset, 1977-97; R.R. Lane, Louisiana State University, unpub. data, 2016). At this concentration, the resulting $\mathrm{NO}_{3}^{-}$loading rate is $11.25 \mathrm{~g} \mathrm{~N} \mathrm{~m}^{-2}$ $\mathrm{yr}^{-1}\left( \pm 4.17 \mathrm{~g} \mathrm{~N} \mathrm{~m}^{-2} \mathrm{yr}^{-1}\right.$ standard deviation), which is within the design criteria of $10-15 \mathrm{~g} \mathrm{~N} \mathrm{~m}^{-2} \mathrm{yr}^{-1}$ set for uptake by assimilation wetlands (Lane and others, 2003), close to median $\mathrm{N}$ removal rates provided for coastal Louisiana wetlands in general (9.31-9.76 $\mathrm{g} \mathrm{N} \mathrm{m}^{-2} \mathrm{yr}^{-1}$; Rivera-Monroy and others, 2013), and should ensure complete $\mathrm{NO}_{3}^{-}$uptake by the swamp vegetation during overland flow under most conditions. Thus, maximum $\mathrm{NO}_{3}^{-}$loading of 7.1-15.4 $\mathrm{g} \mathrm{N} \mathrm{m}^{-2} \mathrm{yr}^{-1}$ would be an acceptable target (fig. 11), while rates lower than $7.1 \mathrm{~g} \mathrm{~N} \mathrm{~m}^{-2}$ $\mathrm{yr}^{-1}$ would not meet the expectation that a river reintroduction would deliver vital nutrients to the wetland vegetation of Maurepas Swamp (unacceptable; fig. 11). It is likely that the Mississippi River reintroduction will be run from January until mid-May and then only opened, when possible, to prevent saltwater intrusion during late summer and fall. Thus, annual loading will be pulsed, which needs to be considered since major pulsing may not coincide with maximum rates of nutrient uptake by the vegetation. $\mathrm{NO}_{3}^{-}$loading will necessarily be higher to wetlands closer to the diversion structure outflow, but at $11.25 \mathrm{~g} \mathrm{~N} \mathrm{~m}^{-2} \mathrm{yr}^{-1}$ of $\mathrm{NO}_{3}^{-}$delivery to the headwaters of Maurepas Swamp, excessive $\mathrm{NO}_{3}^{-}$loading to Lake Maurepas and Blind River should be prevented (fig. 1).

\section{Considerations}

One of the main concerns with regard to any freshwater reintroduction into the upper Lake Pontchartrain Basin is the possibility of excess nutrient loading to Lake Maurepas or Lake Pontchartrain by direct flow of diverted water to the lakes, by nutrient loading in excess of wetland uptake capacity, or through mineralization of nutrients already present in the wetland (primarily $\mathrm{NH}_{4}^{+}$and phosphate $\left[\mathrm{PO}_{4}^{-3}\right]$ ) from new biogeochemical transformations prompted by the freshwater loading. The nutrient of primary concern for this performance measure is $\mathrm{N}$, which in excess quantities delivered from the river reintroduction (defined by this performance measure as $>15.4 \mathrm{~g} \mathrm{~N} \mathrm{~m}^{-2} \mathrm{yr}^{-1}$ ) could lead to algal blooms in the lakes because of incomplete uptake from the swamp. Therefore, we target $\mathrm{N}$ in this performance measure because $\mathrm{N}$ is far more likely to limit photosynthetic rates than $\mathrm{P}$ because river water has N:P ratios ranging between 25:1 and 53:1 (Lane and others, 2003), indicating excess $N$ compared with the 16:1 Redfield ratio for optimal phytoplankton growth (Redfield, 1958). Thus, other major goals of the proposed river reintroduction project are to minimize direct flow of nutrients to the lakes and to assess the capacity of the swamps receiving diverted river water to process and take up the associated nutrients.

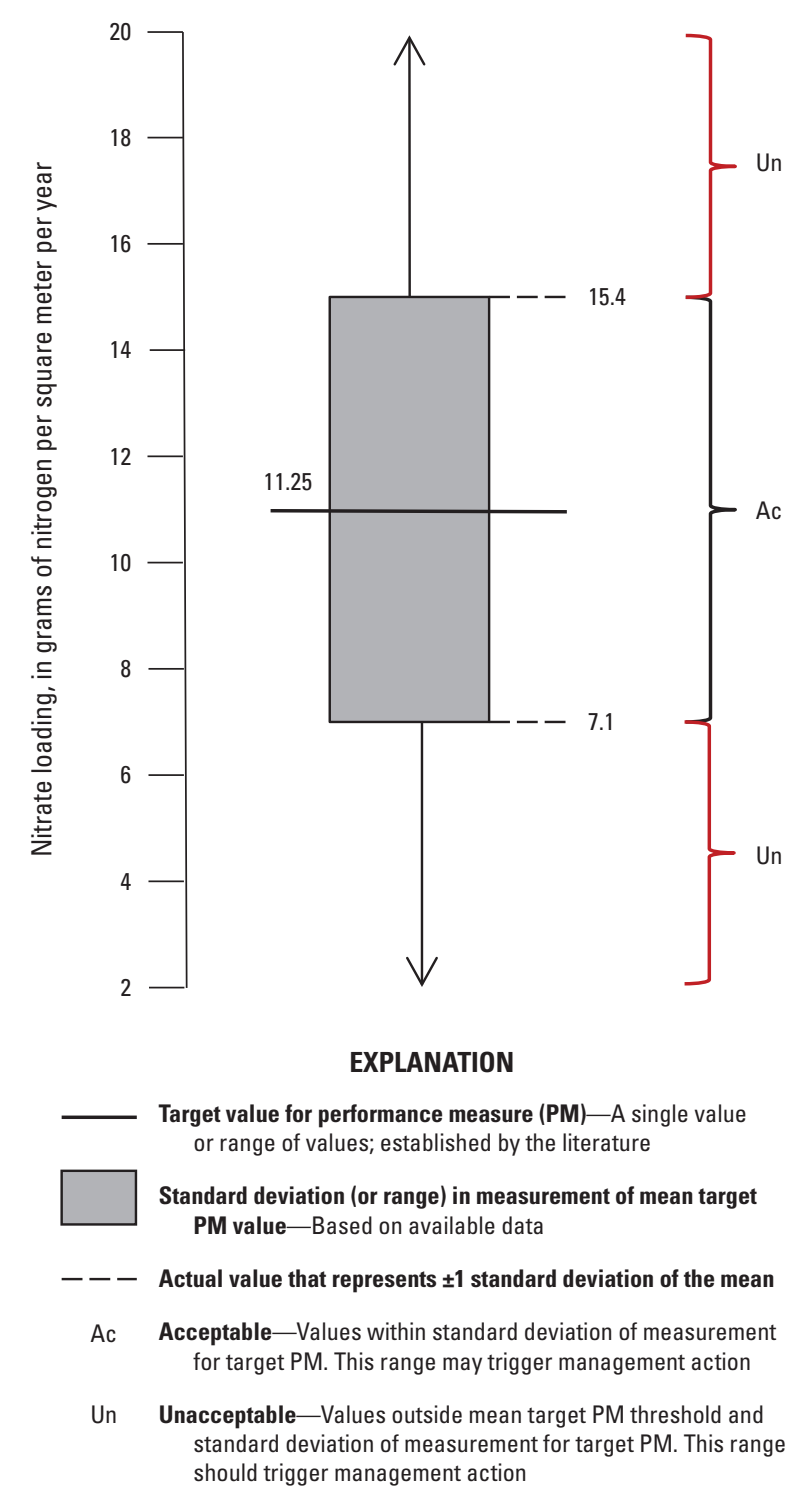

Figure 11. Nitrate $\left(\mathrm{NO}_{3}^{-}\right)$loading acceptability ranges around a target of 11.25 grams $(\mathrm{g})$ of nitrogen $(\mathrm{N})$ per square meter per year $\left(\mathrm{m}^{-2} \mathrm{yr}^{-1}\right)$ associated with a Mississippi River reintroduction into Maurepas Swamp, Louisiana. Assuming an average flow of 42 cubic meters per second, this target loading rate equates to a $\mathrm{NO}_{3}$ - concentration of approximately 1.5 milligrams of $\mathrm{NO}_{3}^{-}$per liter of river water at the diversion structure outflow. Standard deviation for $\mathrm{NO}_{3}$ loading equates to approximately $4.17 \mathrm{~g} \mathrm{~N} \mathrm{~m}^{-2} \mathrm{yr}^{-1}$.

Project attributes including the very limited conveyance capacity of Hope Canal north of U.S. Interstate 10 and outfall management together strongly limit the direct flow of diverted water through Hope Canal to Lake Maurepas and minimize nutrient loading to the lake from water remaining in channel flow. Modeling has shown that the vast majority (greater than 90 percent) of diverted water rapidly leaves the Hope Canal north of Interstate 10 and enters as sheet flow through Maurepas Swamp. 
The ability of Maurepas Swamp to process nutrients associated with this diverted water was also estimated by focusing on $\mathrm{NO}_{3}^{-}$(Day and others, 2004). Both loading and uptake of $\mathrm{NO}_{3}{ }^{-}$was estimated by using results of the UNET hydrologic model (Barkau, 1996) to define the pattern and quantity of flow of diverted water as it moves sequentially through sections of the receiving swamp, estimating average concentrations of $\mathrm{NO}_{3}{ }^{-}$in river water, and determining uptake rates in relation to loading rates based on literature studies (Lee Wilson and Associates, 2001). Sections of the swamp adjacent to Hope Canal and thus directly receiving river water (termed "primary receiving cells") are expected to have the highest $\mathrm{NO}_{3}^{-}$loading rates and uptake rates of 40-70 percent. While this level of $\mathrm{NO}_{3}{ }^{-}$removal is not high, it results in water flowing to the next sections of swamp (termed "secondary receiving cells" because they receive water mainly from primary receiving cells) with much lower $\mathrm{NO}_{3}^{-}$concentrations. The resulting loading rates exiting the secondary receiving cells are associated with removal efficiencies of 90-95 percent (Lane and others, 2003). The reduction in $\mathrm{NO}_{3}{ }^{-}$along the shortest flow pathway, from Hope Canal to Tent Bayou to Dutch Bayou to Blind River, would represent a 94-99-percent reduction in concentration. Subsequent modeling efforts suggest similar reductions of 86 percent of $\mathrm{NO}_{\mathrm{x}}$ during average river reintroduction flows to Maurepas Swamp (Holm and others, 2013). Such N removal brings the original river concentrations down to levels that are in the high end of the range of $\mathrm{NO}_{3}{ }^{-}$concentrations currently measured in the Maurepas Swamp channels (Day and others, 2004). These calculations suggest that little Mississippi River-derived $\mathrm{NO}_{3}^{-}$will reach Lake Maurepas or Blind River if our performance measure is maintained, even if a $42 \mathrm{~m}^{3} / \mathrm{s}$ (about $1,500 \mathrm{ft}^{3} / \mathrm{s}$ ) river reintroduction were operated continuously at full capacity, which is unlikely to occur.

Other nutrients of interest include $\mathrm{NH}_{4}^{+}$, organic $\mathrm{N}$, and $\mathrm{P}\left(\right.$ as $\mathrm{PO}_{4}^{-3}$ ). Since $\mathrm{NH}_{4}^{+}$concentrations in river water are less than one-tenth of $\mathrm{NO}_{3}^{-}$(Lane and others, 2003) and $\mathrm{NH}_{4}^{+}$ commonly oxidizes to $\mathrm{NO}_{3}{ }^{-}$in surface water, loading of $\mathrm{NH}_{4}^{+}$ from a river reintroduction is not of great concern. $\mathrm{NH}_{4}^{+}$also can be regenerated within the wetlands from decomposition of organic matter, leading to an increase in $\mathrm{NH}_{4}^{+}$concentrations downstream from the point of the diversion structure, which has been observed at the Caernarvon freshwater diversion and in wetland treatment systems (Lane and others, 2003). In all of these cases, $\mathrm{NH}_{4}^{+}$concentration increased and then decreased again with distance from the point of the water source. Total organic $\mathrm{N}$ is expected to follow a similar pattern, with concentrations higher in the upper portion of the wetlands, close to the diversion structure, and with concentrations decreasing with distance. $\mathrm{PO}_{4}^{-3}$ concentrations are similar in the river and Maurepas Swamp. Overall, $\mathrm{PO}_{4}^{-3}$ concentrations are not expected to change much in association with a river reintroduction (Lane and others, 2003); uptake of $\mathrm{P}$ (total $\mathrm{P}_{\text {and }} \mathrm{PO}_{4}^{-3}$ ) by Maurepas Swamp wetlands may be as much as 46 percent as river water passes through (Holm and others, 2013).

\section{Assessment Methods}

It is important that periodic measurements are made of $\mathrm{N}$ (nitrite $\left.\left[\mathrm{NO}_{2}^{-2}\right], \mathrm{NO}_{3}^{-}, \mathrm{NH}_{4}^{+}\right)$and $\mathrm{P}\left(\mathrm{PO}_{4}^{-3}\right)$ in the water column at various distances from the diversion structure outfall even though this performance measure focuses on $\mathrm{NO}_{3}^{-}$. In Maurepas Swamp, nutrient limitation may be as great or greater of a stress than saltwater intrusion or excessive flooding (Shaffer and others, 2009a, 2016). The influence of nutrients in river water on the Maurepas Swamp ecosystem can be measured from two perspectives, namely the positive influence on swamp forest productivity (PM4) and any negative influence on lake water quality. The difference between nutrient inputs to and outputs from the swamp can be used to determine removal efficiencies.

\section{Water Quality Analysis}

During the first year of operation, a water quality study implemented similarly to that of Lane and others (2003) would be beneficial, especially if distributed throughout the receiving basin for diverted river waters. Typical constituents include total suspended sediment (TSS); nutrients including $\mathrm{NO}_{3}^{-}, \mathrm{NO}_{2}^{-2}, \mathrm{NH}_{4}^{+}, \mathrm{PO}_{4}^{-3}$, total $\mathrm{N}$ and $\mathrm{P}$; and chlorophyll a as a measure of phytoplankton biomass. Specific extraction methods are detailed in Lane and others (2003) and in other studies on water quality, most of which follow standardized U.S. Environmental Protection Agency protocols. Along with the $\mathrm{NO}_{3}{ }^{-}$targets established herein, any apparent change in other parameters as the Mississippi River reintroduction into Maurepas Swamp is implemented also may be considered. As stated in section "PM 1: Establishing a Hydrologic Regime Consistent With Swamp Forest Sustainability," it will be important to trace the water quality of river water as it passes through the swamp and into Lake Maurepas. Permanent sampling locations set up at different proximities from the diversion structure outfall and monitored on a regular cycle for multiple years would be beneficial to understanding the full nutrient balance. For example, water quality may be monitored monthly for the first 2 years of river reintroduction operation at the same 19 locations monitored in a baseline study (fig. 4 in app. E of Lee Wilson and Associates, 2001). These sampling stations are all boat accessible and cover all of the major bayous and water bodies in Maurepas Swamp, as well as some of the side channels to the main bayous. Results from the first 2 years of water quality monitoring will be used to determine the subsequent monitoring schedule, but will be most useful if it occurs at least at intervals of 5, 10, and 20 years thereafter.

\section{Analysis of Deposited Sediments}

A number of sedimentation monitoring activities were suggested in sections "PM1: Establishing a Hydrologic Regime Consistent With Swamp Forest Sustainability" and "PM3: Increasing Rates of Soil Surface Elevation Gain." Along with these activities, sediments deposited on the soil surface may be periodically measured for chemical 
constituents initially and at least every 5 years. Soil properties measured may include $\mathrm{N}, \mathrm{P}, \mathrm{C}, \mathrm{pH}$, bulk density, and electrical conductivity, as well as a suite of additional metals/nutrients (including iron, magnesium, calcium, copper, manganese, potassium, and zinc) to document accumulation in the soil.

\section{Reference Sites}

Reference sites would fall into two categories: (1) those that are as healthy as possible, accessible, and established in phase with monitoring at Maurepas Swamp and (2) those that are in a degraded or transitional state and representative of the type of swamp forests being rehabilitated by a Mississippi River reintroduction into Maurepas Swamp. Preferably, reference sites would not be affected by the Mississippi River reintroduction into Maurepas Swamp. Healthy reference sites can be used to help determine whether implementation of a river reintroduction is yielding forested wetlands that are functionally equivalent to the best examples of healthy forests in coastal Louisiana, while degraded reference sites will help document continued degradation on those sites relative to potential improvements made in similar forests influenced by the river reintroduction into Maurepas Swamp. In some instances, when trajectories of change are being monitored, we can even determine at what year specific locations in Maurepas Swamp reach functional equivalency to healthy reference forests for specific variables (Stagg and Mendelssohn, 2010; Osland and others, 2012).

While rigorous selection of reference sites is not within the scope of this report, we suggest several locations where such healthy forests, along with nearby degraded or transitional forests, may be found. Candidate healthy sites that we have learned of anecdotally or through our own field experiences are not numerous, however, because the vast majority of wetland forests in coastal Louisiana are in decline (Chambers and others, 2005). Potential sites include various locations in the lower Atchafalaya River Basin, Bayou Chinchuba, Bayou Sale (private lands within CPRA Coastal Forest Conservation Initiative), Bay Wallace, Lac des Allemands, Bonnet Carré Spillway, and Bayou Chevreuil (fig. 12). In addition, there are currently 48 actively monitored swamp sites associated with CRMS (fig. 12); critical selection among these stations will be useful because data collection has been ongoing since 2007. In addition, the CRMS stations are often associated with adjacent marshes, which may broaden our understanding of change in reference condition relative to restored river flow into Maurepas Swamp.

True reference sites for Maurepas Swamp located outside of the impacted basin will be difficult to defend. There is variation among swamp forest conditions in coastal Louisiana, and nearly all sites have some degree of impact related to logging, canal dredging, levees, salinity, and other activities (Chambers and others, 2005). There also have been no similar river reintroduction projects into coastal Louisiana swamps to date. Therefore, it also will be prudent to maintain internal reference sites within Maurepas Swamp even though these will also be affected by the Mississippi River reintroduction. This protocol is required to support some of the performance measure procedures described herein (for example, FFQI). Internal reference forests should consist of healthy sites within Maurepas Swamp that transitional forest under the influence of a river reintroduction may become similar to over time. For example, Shaffer and others (2009a) labeled a series of study plots as "relict," "degraded," and "throughput" within Maurepas Swamp (see app. 1). The throughput plots are much healthier because of their proximity to reliable nonpoint sources of freshwater runoff. These plots could be monitored throughout preconstruction and implementation of the river reintroduction, and while they offer one form of target, it is key to remember that they too will be affected by the river reintroduction.

\section{Conclusions}

A Mississippi River reintroduction into Maurepas Swamp and associated outfall management features collectively should facilitate connectivity of water between the Mississippi River and the entire PO-29 project area for at least half of the year, or other times when the diversion structure outflow is managed at maximum flow, and facilitate periodic water drawdown to promote tree regeneration. The river reintroduction is also anticipated to maintain mean annual pore water salinity in baldcypress-dominated swamp forests to less than $1.3 \mathrm{psu}$ (range, $1.0-1.6 \mathrm{psu}$ ), maintain salinity in mixed baldcypress-water tupelo swamp forests to less than $0.8 \mathrm{psu}$ (range, $0.5-1.1 \mathrm{psu}$ ), promote soil surface elevation gains of 8-9 mm/yr (range, 4.9-12.1 mm/yr) to help offset relative sea-level rise, and keep total river water $\mathrm{NO}_{3}^{-}$loading into Maurepas Swamp to less than $11.25 \mathrm{~g} \mathrm{~N} \mathrm{~m}^{-2}$ $\mathrm{yr}^{-1}$ (range, $7.1-15.4 \mathrm{~g} \mathrm{~N} \mathrm{~m}^{-2} \mathrm{yr}^{-1}$ ) to promote near complete uptake of $\mathrm{NO}_{3}^{-}$by the vegetation in the receiving wetlands and reduce impacts to water quality in Blind River and Lake Maurepas. With these performance measures maintained over time, we further expect swamp forest stands to realize improvements in stand density index of up to $30-45$ percent of maximum values for the stand type while maintaining an overstory leaf area index of 2.0-2.9 or higher as swamp forests recover from decades of low flow, saltwater intrusion, reduced nutrients, and surface elevation deficits associated with isolation from the Mississippi River.

Table 4 provides a list of components requiring measurement and a time table for implementing important monitoring activities associated with performance measures. The monitoring time line spans from preconstruction to 50 years postconstruction. Alterations to this time line may be required as the OMMAM plan is developed, refined, and implemented. For example, a dry winter may be suggestive of a delayed opening of the diversion structure to full volume to later in the spring to facilitate greater soil exposure for regeneration and rapid early seedling growth across Maurepas Swamp. PO-29 is a small river reintroduction in scope and, through its operation, will provide information about the feasibility of and reasonable expectations for future river reintroduction projects targeting coastal swamp forests in Louisiana. 


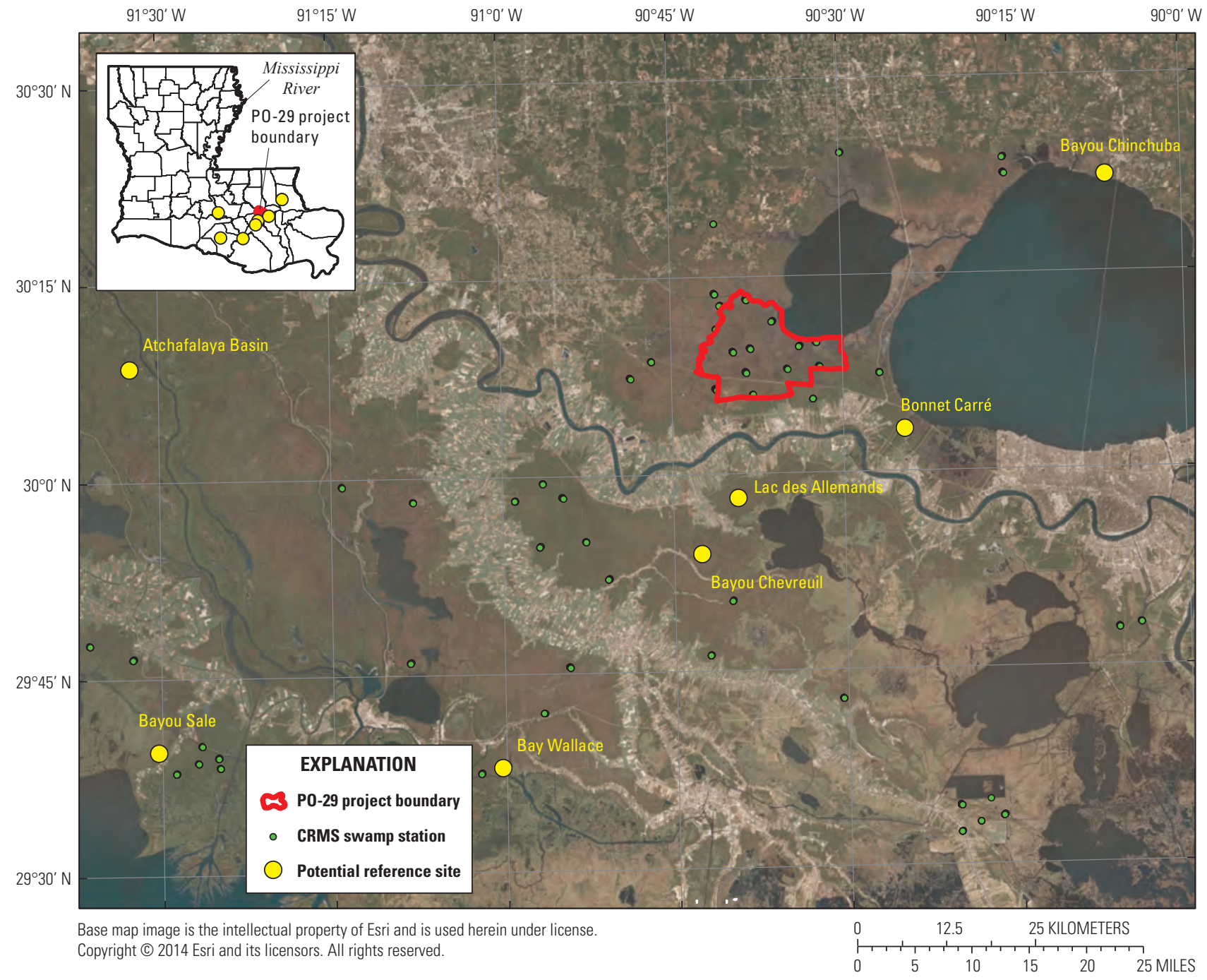

Figure 12. Locations of potential reference sites, including actively monitored swamp stations associated with the Coastwide Reference Monitoring System (CRMS), for monitoring the success of specific performance measures associated with the operation of a Mississippi River reintroduction into Maurepas Swamp, Louisiana. 
Table 4. Time table for initiating components of the monitoring plan for a Mississippi River reintroduction into Maurepas Swamp, Louisiana.

[๑, yes; ๑, no; $\bullet \bullet$, year optional; ${ }^{\mathrm{m}}$, multiple times per year; PM, performance measure; CRMS, Coastwide Reference Monitoring System; SET, surface elevation table; LAI, leaf area index; SDI, stand density index; FFQI, forested floristic quality index]

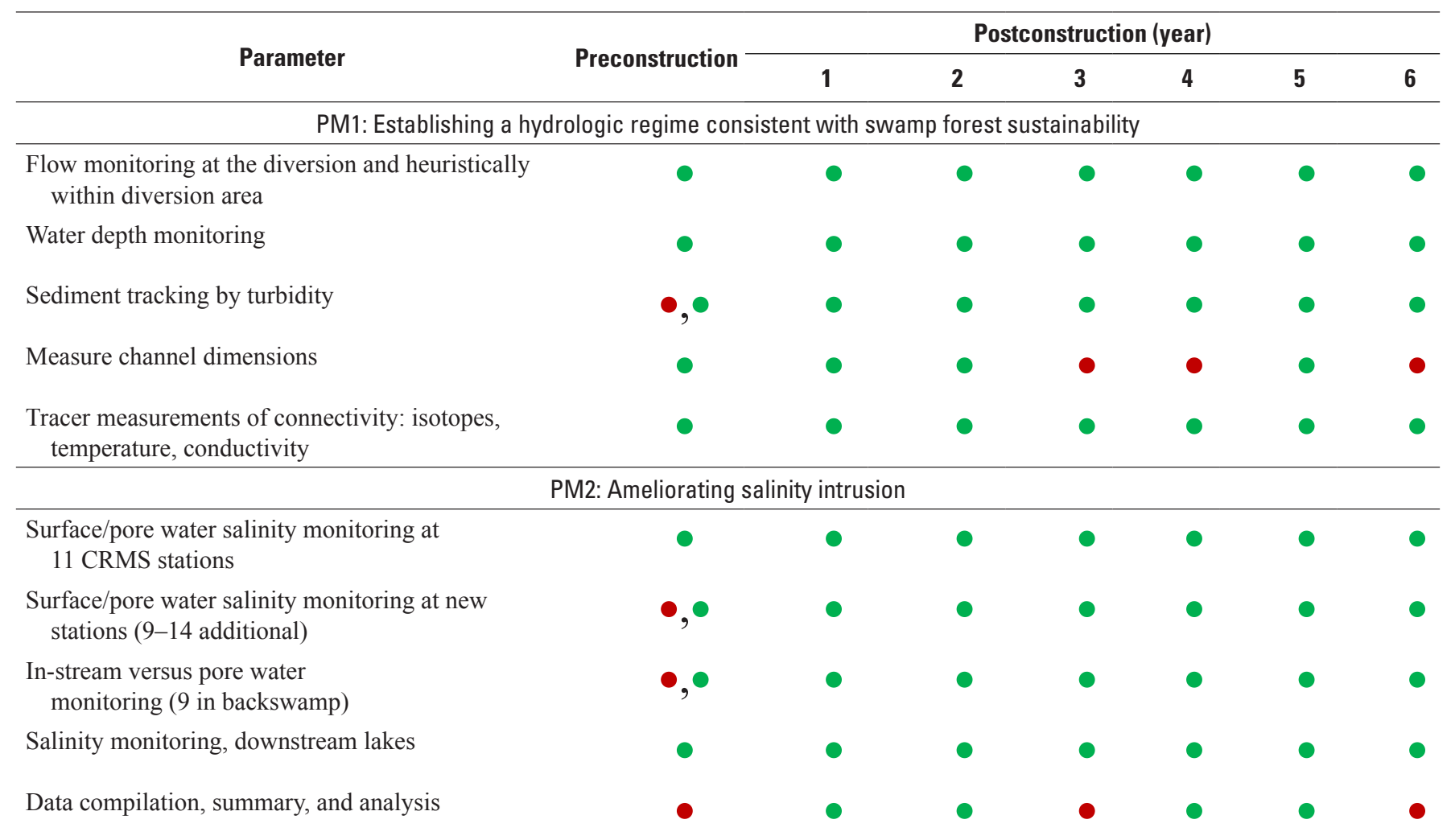

PM3: Increasing rates of soil surface elevation gain

\begin{tabular}{|c|c|c|c|c|c|c|c|}
\hline Radioisotope dating of cores & $\bullet$ & $\bullet$ & $\bullet$ & $\bullet$ & $\bullet$ & $\bullet$ & $\bullet$ \\
\hline Rod SETs (existing) & $\mathrm{m}$ & $\mathrm{m}$ & $\mathrm{m}$ & $\bullet$ & - & $\bullet$ & • \\
\hline Rod SET (new) & $\bullet, \bullet^{\mathrm{m}}$ & $\mathrm{m}$ & $\mathrm{m}$ & - & 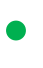 & - & • \\
\hline Repetitive surveying of rod SETs & $\bullet$, & - & - & $\bullet$ & - & $\bullet$ & • \\
\hline \multicolumn{8}{|c|}{ PM4: Increasing forest structural integrity } \\
\hline $\begin{array}{l}\text { Establishment and measurement of new forest } \\
\text { plots (30) }\end{array}$ & $\bullet, \bullet$ & - & $\bullet$ & $\bullet$ & - & $\bullet$ & $\bullet$ \\
\hline Remeasurement of existing forest plots ( 24 plots) & - & $\bullet$ & $\bullet$ & $\bullet$ & $\bullet$ & - & $\bullet$ \\
\hline LAI, SDI, and FFQI measurements/calculations & $\bullet, \bullet$ & $\bullet$ & $\bullet$ & $\bullet$ & $\bullet$ & - & - \\
\hline FFQI analysis intervals & ○ & - & - & $\bullet$ & - & • & $\bullet$ \\
\hline Remote sensing analysis & 0 & - & - & - & $\bullet$ & - & 0 \\
\hline
\end{tabular}

PM5: Facilitating nutrient uptake and retention

\begin{tabular}{|c|c|c|c|c|c|c|}
\hline Establishment of water quality stations (19) & $\bullet,{ }^{\mathrm{m}}$ & $\mathrm{m}$ & $\mathrm{m}$ & • & $\bullet$ & m \\
\hline Analysis of deposited sediments & - & $\bullet$ & - & $\bullet$ & $\bullet$ & ? \\
\hline
\end{tabular}


Table 4. Time table for initiating components of the monitoring plan for a Mississippi River reintroduction into Maurepas Swamp, Louisiana.-Continued

[๑, yes; $\bullet$, no; $\bullet$, , year optional; ${ }^{\mathrm{m}}$, multiple times per year; PM, performance measure; CRMS, Coastwide Reference Monitoring System; SET, surface elevation table; LAI, leaf area index; SDI, stand density index; FFQI, forested floristic quality index]

\begin{tabular}{|c|c|c|c|c|c|c|c|}
\hline \multirow{2}{*}{ Parameter } & \multicolumn{6}{|c|}{ Postconstruction (year) } & \multirow{2}{*}{ Continuous $^{1}$} \\
\hline & 7 & 8 & 9 & 10 & 20 & 50 & \\
\hline \multicolumn{8}{|c|}{ PM1: Establishing a hydrologic regime consistent with swamp forest sustainability } \\
\hline $\begin{array}{l}\text { Flow monitoring at the diversion and heuristically } \\
\text { within diversion area }\end{array}$ & $\bullet$ & $\bullet$ & 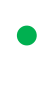 & - & - & 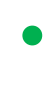 & $\bullet$ \\
\hline Water depth monitoring & $\bullet$ & - & $\bullet$ & - & - & - & $\bullet$ \\
\hline Sediment tracking by turbidity & $\bullet$ & $\bullet$ & $\bullet$ & $\bullet$ & $\bullet$ & $\bullet$ & $\bullet$ \\
\hline Measure channel dimensions & $\bullet$ & $\bullet$ & $\bullet$ & $\bullet$ & - & ○ & $\bullet$ \\
\hline $\begin{array}{l}\text { Tracer measurements of connectivity: isotopes, } \\
\text { temperature, conductivity }\end{array}$ & $\bullet$ & $\bullet$ & $\bullet$ & $\bullet$ & $\bullet$ & • & $\bullet, \bullet$ \\
\hline \multicolumn{8}{|c|}{ PM2: Ameliorating salinity intrusion } \\
\hline $\begin{array}{l}\text { Surface/pore water salinity monitoring at } \\
11 \text { CRMS stations }\end{array}$ & $\bullet$ & $\bullet$ & $\bullet$ & $\bullet$ & $\bullet$ & • & - \\
\hline $\begin{array}{l}\text { Surface/pore water salinity monitoring at new } \\
\text { stations (9-14 additional) }\end{array}$ & $\bullet$ & $\bullet$ & $\bullet$ & $\bullet$ & $\bullet$ & $\bullet$ & $\bullet$ \\
\hline $\begin{array}{l}\text { In-stream versus pore water } \\
\text { monitoring ( } 9 \text { in backswamp) }\end{array}$ & $\bullet$ & $\bullet$ & $\bullet$ & $\bullet$ & $\bullet$ & $\bullet$ & $\bullet$ \\
\hline Salinity monitoring, downstream lakes & $\bullet$ & $\bullet$ & $\bullet$ & $\bullet$ & $\bullet$ & • & $\bullet$ \\
\hline Data compilation, summary, and analysis & $\bullet$ & $\bullet$ & $\bullet$ & - & - & $\bullet$ & $\bullet$ \\
\hline \multicolumn{8}{|c|}{ PM3: Increasing rates of soil surface elevation gain } \\
\hline Radioisotope dating of cores & $\bullet$ & 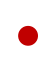 & 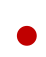 & 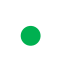 & $\bullet$ & ○ & ? \\
\hline Rod SETs (existing) & $\bullet$ & ○ & $\bullet$ & $\bullet$ & $\bullet$ & $\bullet$ & $\bullet$ \\
\hline Rod SET (new) & $\bullet$ & $\bullet$ & $\bullet$ & $\bullet$ & $\bullet$ & $\bullet$ & $\bullet$ \\
\hline Repetitive surveying of rod SETs & $\bullet$ & $\bullet$ & $\bullet$ & $\bullet$ & $\bullet$ & 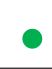 & $\bullet$ \\
\hline \multicolumn{8}{|c|}{ PM4: Increasing forest structural integrity } \\
\hline $\begin{array}{l}\text { Establishment and measurement of new forest } \\
\text { plots (30) }\end{array}$ & $\bullet$ & $\bullet$ & $\bullet$ & $\bullet$ & $\bullet$ & • & $\bullet$ \\
\hline Remeasurement of existing forest plots ( 24 plots) & $\bullet$ & $\bullet$ & $\bullet$ & $\bullet$ & $\bullet$ & $\bullet$ & $\bullet$ \\
\hline LAI, SDI, and FFQI measurements/calculations & $\bullet$ & $\bullet$ & $\bullet$ & - & - & ○ & - \\
\hline FFQI analysis intervals & • & $\bullet$ & $\bullet$ & • & - & ○ & - \\
\hline Remote sensing analysis & $\bullet$ & $\bullet$ & $\bullet$ & ○ & 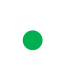 & ○ & $\bullet$ \\
\hline \multicolumn{8}{|c|}{ PM5: Facilitating nutrient uptake and retention } \\
\hline Establishment of water quality stations (19) & $\bullet$ & $\bullet$ & $\bullet$ & $\mathrm{m}$ & $\mathrm{m}$ & $\bullet$ & - \\
\hline Analysis of deposited sediments & $\bullet$ & $\bullet$ & $\bullet$ & $\bullet$ & - & ○ & $\bullet$ \\
\hline
\end{tabular}

\footnotetext{
1"Continuous" refers to data collected through standard datalogger methods, such as water level or salinity data recorded every 15 minutes. When "continuous" is selected, data collection equivalent to "multiple times per year" is implied.
} 


\section{References Cited}

Abtew, W., and Melesse, A., 2013, Wetland restoration assessment using remote sensing- and surface energy budgetbased evapotranspiration, in Abtew, W., and Melesse, A., eds., Evaporation and Evapotranspiration, Measurements and Estimations: New York, Springer, p. 177-195.

Allain, L., Smith, L., Allen, C., Vidrine, M.F., and Grace, J.B., 2006, A floristic quality assessment system for the coastal prairie of Louisiana, in Egan, D., and Harrington, J.A., eds., Proceedings of the 19th North American Prairie Conference: Madison, University of Wisconsin, p. 1-18.

Allen, J.A., 1992, Cypress-tupelo swamp restoration in southern Louisiana: Restoration and Management Notes, v. 10, p. $188-189$.

Allen, J.A., 1994, Intraspecific variation in the response of baldcypress (Taxodium distichum) seedlings to salinity: Baton Rouge, Louisiana State University, Ph.D. dissertation, $183 \mathrm{p}$.

Allen, S.T., Whitsell, M.L., and Keim, R.F., 2015, Leaf morphometrics and allometrics in baldcypress: Canadian Journal of Forest Research, v. 45, p. 963-969.

Allen, Y.C., Constant, G.C., and Couvillion, B.R., 2008, Preliminary classification of water areas within the Atchafalaya River Basin Floodway system by using Landsat Imagery: U.S. Geological Survey Open-File Report 2008-1320.

Alsdorf, D.E., Rodríguez, E., and Lettenmaier, D.P., 2007, Measuring surface water from space: Reviews of Geophysics, v. 45, p. RG2002.

Anisfeld, S.C., and Hill, T.D., 2012, Fertilization effects on elevation change and belowground carbon balance in a Long Island Sound tidal marsh: Estuaries and Coasts, v. 35, p. 201-211.

Barkau, R.L., 1996, UNET one-dimensional unsteady flow through a full network of open channels-User's manual: Davis, California, U.S. Army Corps of Engineers, Hydrologic Engineering Center.

Barras, J.A., Bernier, J.C., and Morton, R.A., 2008, Land area change in coastal Louisiana-A multidecadal perspective (from 1956 to 2006): U.S. Geological Survey Scientific Investigations Map 3019, 14 p.

Battaglia, L.L., Sharitz, R.R., and Minchin, P.R., 1999, Patterns of seedling and overstory composition along a gradient of hurricane disturbance in an old-growth bottomland hardwood community: Canadian Journal of Forest Research, v. 29, p. $144-156$.
Battaglin, W.A., Kendall, C., Chang, C.C.Y., Silva, S.R., and Campbell, D.H., 2001, Chemical and isotopic evidence of nitrogen transformation in the Mississippi River, 1997-98: Hydrological Processes, v. 15, p. 1285-1300.

Bechtold, J.S., Edwards, R.T., and Naiman, R.J., 2003, Biotic versus hydrologic control over seasonal nitrate leaching in a floodplain forest: Biogeochemistry, v. 63, p. 53-71.

Beville, S.L., 2002, The efficacy of a small-scale freshwater diversion for restoration of a swamp in southeastern Louisiana: Hammond, Southeastern Louisiana University, M.S. thesis.

Boumans, R.M.J., and Day, J.W., Jr., 1993, High precision measurements of sediment elevation in shallow coastal areas using a sedimentation-erosion table: Estuaries, v. 16, p. $375-380$.

Brantley, C.G., Day, J.W., Jr., Lane, R.R., Hyfield, E., Day, J.N., and Ko, J.-Y., 2008, Primary production, nutrient dynamics, and accretion of a coastal freshwater forested assimilation system in Louisiana: Ecological Engineering, v. 34, p. 7-22.

Britsch, L.D., and Dunbar, J.B., 1993, Land loss ratesLouisiana coastal plain: Journal of Coastal Research, v. 9, p. 324-338.

Brown, S., 1981, A comparison of the structure, primary productivity, and transpiration of cypress ecosystems in Florida: Ecological Monographs, v. 51, p. 403-427.

Buresh, R.J., DeLaune, R.D., and Patrick, W.H., Jr., 1980, Nitrogen and phosphorus distribution and utilization by Spartina alterniflora in a Louisiana gulf coast marsh: Estuaries, v. 3, p. 111-121.

Cahoon, D.R., 2015, Estimating relative sea-level rise and submergence potential as a coastal wetland: Estuaries and Coasts, v. 38, p. 1077-1084.

Cahoon, D.R., Day, J.W., Jr., and Reed, D.J., 1999, The influence of surface and shallow subsurface soil processes on wetland elevation-A synthesis: Current Topics in Wetland Biogeochemistry, v. 3, p. 72-88.

Cahoon, D.R., Hensel, P.F., Spencer, T., Reed, D.J., McKee, K.L., and Saintilan, N., 2006, Coastal wetland vulnerability to relative sea-level rise-Wetland elevation trends and process controls, in Verhoeven, J.T.A., Beltman, B., Bobbink, R., and Whigham, D.F., eds., Wetlands and Natural Resource Management: New York, Springer, p. 271-292.

Cahoon, D.R., and Lynch, J.C., 1997, Vertical accretion and shallow subsidence in a mangrove forest of southwestern Florida, U.S.A.: Mangroves and Salt Marshes, v. 1, p. 173-186. 
Cahoon, D.R., Lynch, J.C., Perez, B.C., Segure, B., Holland, R.D., Stelly, C., Stephenson, G., and Hensel, P., 2002, High precision measurement of wetland sediment elevation-II. The rod surface elevation table: Journal of Sedimentary Research, v. 72, p. 734-739.

Carey, J., 2013, Architects of the swamp: Scientific American, v. 309, p. 74-79.

Carpenter, K., Sasser, C.E., Visser, J.M., and DeLaune, R.D., 2007, Sediment input into a floating freshwater marshEffects on soil properties, buoyancy, and plant biomass: Wetlands, v. 27, p. 1016-1024.

Carrell, C.E., 2009, Assembly rules and hurricane induced wetland habitat-state change: Hammond, Southeastern Louisiana University, M.S. thesis, 84 p.

Chabreck, R.H., 1972, Vegetation, water and soil characteristics of the Louisiana coastal region: Baton Rouge, Louisiana State University Agricultural Experimental Station, Bulletin 664, 72 p.

Chambers, J.L., Conner, W.H., Day, J.W., Jr, Faulkner, S.P., Gardiner, E.S., Hughes, M.S., Keim, R.F., King, S.L., McLeod, K.W., Miller, C.A., Nyman, J.A., and Shaffer, G.P., 2005, Conservation, protection and utilization of Louisiana's coastal wetland forests: Baton Rouge, Final report to the Governor of Louisiana from the Coastal Wetland Forest Conservation and Use Science Working Group, 102 p.

Coastal Protection and Restoration Authority of Louisiana, 2016, Louisiana Coastal Protection and Restoration Authority Coastal Information Management System [CIMS]: Coastal Protection and Restoration Authority of Louisiana, accessed September 14, 2016, at https://cims.coastal. louisiana.gov/default.aspx.

Cohen, M.J., Carstenn, S., and Lane, C.R., 2004, Floristic quality indices for biotic assessment of depressional marsh condition in Florida: Ecological Applications, v. 14, p. 784-794.

Conner, W.H., and Day, J.W., Jr., 1988, Rising water levels in coastal Louisiana-Implications for two coastal forested wetland areas in Louisiana: Journal of Coastal Research, v. 4, p. 589-596.

Conner, W.H., Duberstein, J.A., Day, J.W., Jr., and Hutchinson, S., 2014, Impacts of changing hydrology and hurricanes on forest structure and growth along a flooding/elevation gradient in a south Louisiana forested wetland from 1986 to 2009: Wetlands, v. 34, p. 803-814.

Conner, W.H., Gosselink, J.G., and Parrondo, R.T., 1981, Comparison of the vegetation of three Louisiana swamp sites with different flooding regimes: American Journal of Botany, v. 68, p. 320-331.
Conner, W.H., and Toliver, J.R., 1990, Long-term trends in the bald-cypress (Taxodium distichum) resource in Louisiana (U.S.A.): Forest Ecology and Management, v. 33/34, p. 543-557.

Cormier, N., Krauss, K.W., and Conner, W.H., 2013, Periodicity in stem growth and litterfall in tidal freshwater forested wetlands - Influence of salinity and drought on nitrogen recycling: Estuaries and Coasts, v. 36, p. 533-546.

Couvillion, B.R., Barras, J.A., Steyer, G.D., Sleavin, W., Fischer, M., Beck, H., Trahan, N., Griffin, B., and Heckman, D., 2011, Land area change in coastal Louisiana from 1932 to 2010: U.S. Geological Survey Scientific Investigations Map 3164, 12 p.

Craft, C.B., 2012, Tidal freshwater forest accretion does not keep pace with sea level rise: Global Change Biology, v. 18, p. 3615-3623.

Cretini, K.F., Visser, J.M., Krauss, K.W., and Steyer, G.D., 2011, CRMS vegetation analytical team frameworkMethods for collection, development, and use of vegetation response variables: U.S. Geological Survey Open-File Report 2011-1097, 60 p., accessed November 22, 2011, at https://pubs.usgs.gov/of/2011/1097/.

Cretini, K.F., Visser, J.M., Krauss, K.W., and Steyer, G.D., 2012, Development and use of a floristic quality index for coastal Louisiana marshes: Environmental Monitoring and Assessment, v. 184, p. 2389-2403.

Curtis, J.T., and McIntosh, R.P., 1950, The interrelations of certain analytic and synthetic phytosociological characters: Ecology, v. 31, p. 434-455.

Curtis, R.O., 1970, Stand density measures-An interpretation: Forest Science, v. 16, p. 403-414.

Darby, F.A., and Turner, R.E., 2008a, Below- and aboveground Spartina alterniflora production in a Louisiana salt marsh: Estuaries and Coasts, v. 31, p. 223-231.

Darby, F.A., and Turner, R.E., 2008b, Effects of eutrophication on salt marsh root and rhizome accumulation: Marine Ecology Progress Series, v. 363, p. 63-70.

Darby, F.A., and Turner, R.E., 2008c, Below- and aboveground biomass of Spartina alterniflora: response to nutrient addition in a Louisiana salt marsh: Estuaries and Coasts, v. 31 , p. $326-334$.

Day, J.W., Jr., Britsch, L.D., Hawes, S.R., Shaffer, G.P., Reed, D.J., and Cahoon, D.R., 2000, Pattern and process of land loss in the Mississippi Delta-A spatial and temporal analysis of wetland habitat change: Estuaries, v. 23, p. 425-438. 
Day, J.W., Jr., Hunter, R., Keim, R.F., DeLaune, R.D., Shaffer G.P., Evers, E., Reed, D., Brantley, C., Kemp, P., Day, J.N., and Hunter, M., 2012, Ecological response of forested wetlands with and without large-scale Mississippi River input-Implications for management: Ecological Engineering, v. 46, p. 57-67.

Day, J.W., Jr., Ibañez, C., Scarton, F., Pont, D., Hensel, P., Day, J.N., and Lane, R., 2011b, Sustainability of Mediterranean deltaic and lagoon wetlands with sea-level rise-The importance of river input: Estuaries and Coasts, v. 34, p. 483-493.

Day, J.W., Jr., Kemp, G.P., Reed, D.J., Cahoon, D.R., Boumans, R.M., Suhayda, J.M., and Gambrell, R., 2011a, Vegetation death and rapid loss of surface elevation in two contrasting Mississippi Delta salt marshes-The role of sedimentation, autocompaction and sea-level rise: Ecological Engineering, v. 37, p. 229-240.

Day, J.W., Jr., Ko, J.-Y., Rybczyk, J., Sabins, D., Bean, R., Berthelot, G., Brantkey, C., Cardoch, L., Conner, W., Day, J.N., Englande, A.J., Feagley, S., Hyfield, E., Lane, R., Lindsey, J., Mistich, J., Reyes, E., and Twilley, R., 2004, The use of wetlands in the Mississippi Delta for wastewater assimilation-A review: Journal of Ocean and Coastal Management, v. 47, p. 671-691.

Day, J.W., Jr., Westphal, A., Pratt, R., Hyfield, E., Rybczyk, J., Kemp, G.P., Day, J.N., and Marx, B., 2006, Effects of long-term municipal effluent discharge on the nutrient dynamics, productivity, and benthic community structure of a tidal freshwater forested wetland in Louisiana: Ecological Engineering, v. 27, p. 242-257.

Day, R.H., Williams, T.M., and Swarzenski, C.M., 2007, Hydrology of tidal freshwater forested wetlands of the southeastern United States, in Conner, W.H., Doyle, T.W., and Krauss, K.W., eds., Ecology of tidal freshwater forested wetlands of the southeastern United States: New York, Springer, p. 29-63.

Dean, T.J., and Baldwin, V.C., 1996, The relationship between Reineke's stand-density index and physical stem mechanics: Forest Ecology and Management, v. 81, p 25-34.

DeBell, D.S., and Naylor, A.W., 1972, Some factors affecting germination of swamp tupelo seeds: Ecology, v. 53, p. 504-506.

Deegan, L., Johnson, D.S., Warren, R.S., Peterson, B.J., Fleeger, J.W., Fagherazzi, S., and Wollheim, W.M., 2012, Coastal eutrophication as a driver of salt marsh loss: Nature, v. 490 , p. $388-392$.

DeLaune, R.D., Patrick, W.H., Jr., and Pezeshki, S.R., 1987, Foreseeable flooding and death of coastal wetland forests: Environmental Conservation, v. 14, p. 129-133.
Doyle, T.W., Keeland, B.D., Gorham, L.E., and Johnson, D.J., 1995, Structural impact of Hurricane Andrew on the forested wetlands of the Atchafalaya Basin in south Louisiana: Journal of Coastal Research, Special Issue 21, p. 354-364.

Drexler, J.Z., Krauss, K.W., Sasser, M.C., Fuller, C.C., Swarzenski, C.M., Powell, A., Swanson, K.M., and Orlando, J., 2013, A long-term comparison of carbon sequestration rates in impounded and naturally tidal freshwater marshes along the lower Waccamaw River, South Carolina: Wetlands, v. 33, p. 965-974.

Duberstein, J.A., Conner, W.H., and Krauss, K.W., 2014, Woody vegetation communities of tidal freshwater swamps in South Carolina, Georgia and Florida (US) with comparisons to similar systems in the US and South America: Journal of Vegetation Science, v. 25, p. 848-862.

Ducey, M.J., and Larson, B.C., 1999, Accounting for bias and uncertainty in nonlinear stand density indices: Forest Science, v. 45 , p. 452-457.

Effler, R.S., Goyer, R.A., and Lenhard, G.J., 2006, Baldcypress and water tupelo responses to insect defoliation and nutrient augmentation in Maurepas Swamp, Louisiana: Forest Ecology and Management, v. 236, p. 295-304.

Effler, R.S., Shaffer, G.P., Hoeppner, S.S., and Goyer, R.A., 2007, Ecology of the Maurepas Swamp-Effects of salinity, nutrients, and insect defoliation, in Conner, W.H., Doyle, T.W., and Krauss, K.W., eds., Ecology of tidal freshwater forested wetlands of the southeastern United States: New York, Springer, p. 349-384.

Ervin, G.N., Herman, B.D., Bried, J.T., and Holly, D.C., 2006, Evaluating non-native species and wetland indicator status as components of wetlands floristic assessment: Wetlands, v. 26 , p. 1114-1129.

Faulkner, S.P., Bhattarai, P., Allen, Y., Barras, J., and Constant, G., 2009, Identifying baldcypress-water tupelo regeneration classes in forested wetlands of the Atchafalaya Basin, Louisiana: Wetlands, v. 29, p. 809-817.

Floyd, R.P., 1978, Geodetic bench marks: Rockville, Maryland, National Oceanic and Atmospheric Administration manual NOS NGS 1, 52 p.

Folse, T.M., Sharp, L.A., West, J.L., Hymel, M.K., Troutman, J.P., McGinnis, T.E., Weifenbach, D., Boshart, W.M., Rodrigue, L.B., Richardi, D.C., Wood, W.B., and Miller, C.M., 2014, A Standard operating procedures manual for the Coast-Wide Reference Monitoring System-WetlandsMethods for site establishment, data collection, and quality assurance/quality control: Baton Rouge, Louisiana Coastal Protection and Restoration Authority, Office of Coastal Protection and Restoration, 228 p., accessed April 4, 2017, at http://cims.coastal.la.gov. 
Fox, L., Valiela, I., and Kinney, E.L., 2012, Vegetation cover and elevation in long-term experimental nutrient-enrichment plots in Great Sippewissett Salt Marsh, Cape Cod, Massachusetts-Implications for eutrophication and sea level rise: Estuaries and Coasts, v. 35, p. 445-458.

Giblin, A., Bourg, A., Valiela, I., and Teal, J.M., 1980, Uptake and losses of heavy metals in sewage sludge by a New England salt marsh: American Journal of Botany, v. 67, p. 1059-1068.

Giblin, A.E., Luther, G.W. III, and Valiela, I., 1986, Trace metal solubility in salt marsh sediments containing sewage sludge: Estuarine, Coastal and Shelf Science, v. 23, p. 477-498.

Goelz, J.C.G., 1995, Stocking guides for water tupelo and baldcypress: Southern Journal of Applied Forestry, v. 19, p. 105-108.

Graham, S.A., and Mendelssohn, I.A., 2014, Coastal wetland stability maintained by counterbalancing accretionary responses to chronic nutrient enrichment: Ecology, v. 95, p. 3271-3283.

Hackney C.T., Avery, G.B., Leonard, L.A., Posey, M., and Alphin, T., 2007, Biological, chemical, and physical characteristics of tidal freshwater swamp forests of the Lower Cape Fear River/Estuary, North Carolina, in Conner, W.H., Doyle, T.W., and Krauss, K.W., eds., Ecology of tidal freshwater forested wetlands of the southeastern United States: New York, Springer, p. 183-221.

Haines, B.L., and Dunn, E.L., 1976, Growth and resource allocation responses of Spartina alterniflora Loisel to three levels of $\mathrm{NH}_{4}-\mathrm{N}, \mathrm{Fe}$ and $\mathrm{NaCl}$ in solution culture: Botanical Gazette, v. 137, p. 224-230.

Haines, E.B., 1979, Growth dynamics of cordgrass, Spartina alterniflora Loisel, on control and sewage sludge fertilized plots in a Georgia salt marsh: Estuaries, v. 2, p. 50-53.

Hargis, T.G., and Twilley, R.R., 1994, Improved coring device for measuring soil bulk density in a Louisiana deltaic marsh: Journal of Sedimentary Research, v. 64A, p. 681-683.

Harms, W.R., Schreuder, H.T., Hook, D.D., and Brown, C.L., 1980, The effects of flooding on the swamp forest in Lake Ocklawaha, Florida: Ecology, v. 61, p. 1412-1421.

Harris, J.A., and Hobbs, R.J., 2001, Clinical practice for ecosystem health: the role of ecological restoration: Ecosystem Health, v. 7, p. 195-202.

Hijuelos, A.C., and Reed, D.J., 2013, An approach to identifying environmental and socio-economic performance measures for coastal Louisiana: Baton Rouge, Louisiana, The Water Institute of the Gulf, $34 \mathrm{p}$.
Hillmann, E.R., 2011, The implications of nutrient loading on deltaic wetlands: Hammond, Southeastern Louisiana University, M.S. thesis.

Hodges, J.D., 1997, Development and ecology of bottomland hardwood sites: Forest Ecology and Management, v. 90, p. 117-125.

Hoeppner, S.S., Shaffer, G.P., and Perkins, T.E., 2008, Through droughts and hurricanes - Tree mortality, forest structure, and biomass production in a coastal swamp targeted for restoration in the Mississippi River Deltaic Plain: Forest Ecology and Management, v. 256, p. 937-948.

Holm, G.O., Jr., Perez, B.P., and Bays, J, 2013, Nitrogen and phosphorus removal estimates for existing and planned Mississippi River diversions: Baton Rouge, Report prepared by CH2M-Hill for Louisiana Coastal Protection and Restoration Authority.

Hook, D.D., 1984, Waterlogging tolerance of lowland tree species of the South: Southern Journal of Applied Forestry, v. 8, p. 136-149.

Hsueh, Y., Chambers, J.L., Krauss, K.W., Allen, S.T., and Keim, R.F., 2016, Hydrologic exchanges and baldcypress water use on deltaic hummocks, Louisiana, USA: Ecohydrology, v. 9, p. 1452-1463.

Hughes, F.M.R., 1997, Floodplain biogeomorphology: Progress in Physical Geography, v. 21, p. 501-529.

Huguenin, R.L., Karaska, M.A., van Blairicom, D., and Jensen, J.R., 1997, Subpixel classification of bald cypress and tupelo gum trees in thematic mapper imagery: Photogrammetric Engineering and Remote Sensing, v. 63, p. 717-725.

Hunter, R.G., Day, J.W., Jr., Lane, R.R., Lindsey, J., Day, J.N., and Hunter, M.G., 2009a, Impacts of secondarily treated municipal effluent on a freshwater forested wetland after 60 years of discharge: Wetlands, v. 29, p. 363-371.

Hunter, R.G., Lane, R.R., Day, J.W., Jr., Lindsey, J., Day, J.N., and Hunter, M., 2009b, Nutrient removal and loading rate analysis of Louisiana forested wetlands assimilating treated municipal effluent: Environmental Management, v. 44, p. $865-873$.

Hunter, R.G., Shaffer, G.P., Lane, R.R. and Day, J.W., Jr., 2015, Analysis of long-term productivity and nutrient removal at assimilation wetlands in coastal Louisiana: Baton Rouge, Louisiana Department of Environmental Quality, LDEQ OCR No. 855-400144, 70 p.

Izdepski, C.W., Day, J.W., Jr., Sasser, C.E, and Fry, B., 2009, Early floating marsh establishment and growth dynamics in a nutrient amended wetland in the lower Mississippi Delta: Wetlands, v. 29, p. 1004-1013. 
Jackson, L.L., Lopoukhine, N., and Hillyard, D., 1995, Ecological restoration-A definition and comments: Restoration Ecology, v. 3, p. 71-75.

Johnson, R.L., 1990, Nyssa aquatica L. water tupelo, in Burns, R.M., Honkala, B.H., tech. coords., Silvics of North America, v. 2, Hardwoods: Washington, D.C., U.S. Department of Agriculture, Agricultural Handbook 654, p. 474-478.

Kaller, M.D., Keim, R.F., Edwards, B.L., Harlan, A.R., Pasco, T.E., Kelso, W.E., and Rutherford, D.A., 2015, Aquatic vegetation mediates the relationship between hydrologic connectivity and water quality in a managed floodplain, Atchafalaya River, Louisiana, USA: Hydrobiologia, v. 760, p. 29-41.

Keim, R.F., Braud, D.H., Shaffer, G.P., Chambers, J.L., 2010a, Mapping coastal wetland forests in coastal Louisiana: Baton Rouge, Louisiana Department of Environmental Quality, 21 p.

Keim, R.F., Chambers, J.L., Hughes, M.S., Nyman, J.A., Miller, C.A., and Amos, J.B., 2006, Ecological consequences of changing hydrological conditions in wetland forests of coastal Louisiana, in Xu, Y.J., and Singh, V.P., eds., Coastal environment and water quality, challenges in coastal hydrology and water quality: Highlands Ranch, Colorado, Water Resource Publications, p. 383-395.

Keim, R.F., Dean, T.J., and Chambers, J.L., 2013a, Flooding effects on stand development in cypress-tupelo, in Proceedings, 15th Biennial Southern Silvicultural Research Conference: U.S. Department of Agriculture Forest Service General Technical Report SRS-175, p. 431-437.

Keim, R.F., Dean, T.J., Chambers, J.L., and Conner, W.H., 2010b, Density relationships in baldcypress: Forest Science, v. 56, p. $336-343$.

Keim, R.F., Izdepski, C.W., and Day, J.W., Jr, 2012, Growth response of baldcypress to wastewater nutrient additions and changing hydrological regime: Wetlands, v. 32 , p. $95-103$.

Keim, R.F., Zoller, J.A., Braud, D.H., and Edwards, B., 2013b, Classification of forested wetland degradation using ordination of multitemporal reflectance: Wetlands, v. 33, p. $1103-1115$.

Kendall, C., and Caldwell, E.A., 1998, Fundamentals of isotope geochemistry, in Kendall, C., and McDonnell, J.J., eds., Isotope tracers in catchment hydrology: Amsterdam, Elsevier, p. 51-86.

Kendall, C., and Coplen, T.B., 2001, Distribution of oxygen-18 and deuterium in river waters across the United States: Hydrological Processes, v. 15, p. 1363-1393.

Kendall, C., and McDonnell, J.J., 1998, Isotope tracers in catchment hydrology: Amsterdam, Elsevier.
Kesel, R.H., 1988, The decline in the suspended load of the lower Mississippi River and its influence on adjacent wetlands: Environmental Geology and Water Science, v. 11, p. 271-281.

Kimmins, J.P., 1995, Sustainable development in Canadian forestry in the face of changing paradigms: The Forestry Chronicle, v. 71, p. 33-40.

Kozlowski, T.T., 1984, Responses of woody plants to flooding, in Kozlowski, T.T., ed., Flooding and plant growth: New York, Academic Press, p. 129-163.

Krauss, K.W., Barr, J.G., Engel, V., Fuentes, J.D., and Wang, H., 2015, Approximations of stand water use versus evapotranspiration from three forests in southeast Florida, USA: Agricultural and Forest Meteorology, v. 213, p. 291-303.

Krauss, K.W., Chambers, J.L., and Creech, D., 2007, Selection for salt tolerance in tidal freshwater swamp speciesAdvances using baldcypress as a model for restoration, in Conner, W.H., Doyle, T.W., and Krauss, K.W., eds., Ecology of tidal freshwater forested wetlands of the southeastern United States: New York, Springer, p. 385-410.

Krauss, K.W., and Duberstein, J.A., 2010, Sapflow and water use of freshwater wetland trees exposed to saltwater incursion in a tidally influenced South Carolina watershed: Canadian Journal of Forest Research, v. 40, p. 525-535.

Krauss, K.W., Duberstein, J.A., Doyle, T.W., Conner, W.H., Day, R.H., Inabinette, L.W., and Whitbeck, J.L., 2009, Site condition, stand structure, and growth of baldcypress along tidal/non-tidal salinity gradients: Wetlands, v. 29, p. 505-519.

Krauss, K.W., McKee, K.L., Lovelock, C.E., Cahoon, D.R., Saintilan, N., Reef, R., and Chen, L., 2014, How mangrove forests adjust to rising sea level: New Phytologist, v. 202, p. 19-34.

Kroes, D.E., and Kraemer, T.F., 2013, Human-induced stream channel abandonment/capture and filling of floodplain channels within the Atchafalaya River Basin, Louisiana: Geomorphology, v. 201, p. 148-156.

Lane, R.R., Mashriqui, H.S., Kemp, G.P., Day, J.W., Jr., Day, J.N., and Hamilton, A., 2003, Potential nitrate removal from a river diversion into a Mississippi Delta forested wetland: Ecological Engineering, v. 20, p. 237-249.

Lee Wilson \& Associates, 2001, Diversion into the Maurepas swamps-A complex project under the Coastal Wetlands Planning, Protection, and Restoration Act: Dallas, Texas, U.S. Environmental Protection Agency Region 6, 60 p.

Lockaby, B.G., and Conner, W.H., 1999, N:P balance in wetland forests - Productivity across a biogeochemical continuum: The Botanical Review, v. 65, p. 171-185. 
Long, J.N., and Smith, F.W., 1984, Relation between size and density in developing stands-A description and possible mechanisms: Forest Ecology and Management, v. 7, p. 191-206.

Lopez, R.D., and Fennessy, M.S., 2002, Testing the floristic quality assessment index as an indicator of wetland condition: Ecological Applications, v. 12, p. 487-497.

Lott, R.B., and Hunt, R.J., 2001, Estimating evapotranspiration in natural and constructed wetlands: Wetlands, v. 21, p. 614-628.

Lovelock, C.E., Cahoon, D.R., Friess, D.A., Guntenspergen, G.R., Krauss, K.W., Reef, R., Rogers, K., Saunders, M.L., Sidik, F., Swales, A., Saintilan, N., Thuyen, L.X., and Triet, T., 2015, The vulnerability of Indo-Pacific mangrove forests to sea-level rise: Nature, v. 526, p. 559-563.

Lu, Z., Crane, M., Kwoun, O.-I., Wells, C., Swarzenski, C., and Rykhus, R., 2005, C-band radar observes water level change in swamp forests: Eos, Transactions American Geophysical Union, v. 86, p. 141-144.

Lundberg, C.J., 2008, Using secondarily treated sewage effluent to restore the baldcypress-water tupelo swamps of the Lake Pontchartrain Basin-A demonstration study: Hammond, Southeastern Louisiana University, M.S. thesis, 85 p.

Lundberg, C.J., Shaffer, G.P., Wood, W.B., and Day, J.W., Jr., 2011, Growth rates of baldcypress (Taxodium distichum) seedlings in a treated effluent assimilation marsh: Ecological Engineering, v. 37, p. 549-553.

Lynch, J.C., Meriweather, J., McKee, B., Vera-Herrera, F., and Twilley, R.R., 1989, Recent accretion in mangrove ecosystems based on ${ }^{137} \mathrm{Cs}$ and ${ }^{210} \mathrm{~Pb}$ : Estuaries, v. 12, p. $284-299$.

Maloszewski, P., and Zuber, A., 1993, Principles and practice of calibration and validation of mathematical models for the interpretation of environmental tracer data: Advances in Water Resources, v. 16, p. 173-190.

Mancil, E., 1980, Pullboat logging: Journal of Forest History, v. 24, p. $135-141$.

McKee, K.L., Cahoon, D.R., and Feller, I.C., 2007, Caribbean mangroves adjust to rising sea level through biotic controls on change in soil elevation: Global Ecology and Biogeography, v. 16 , p. 545-556.

McLeod, K.W., McCarron, J.K., and Conner, W.H., 1996, Effects of flooding and salinity on photosynthesis and water relations of four Southeastern Coastal Plain forest species: Wetlands Ecology and Management, v. 4, p. 31-42.

Mertes, L.A., 2002, Remote sensing of riverine landscapes: Freshwater Biology, v. 47, p. 799-816.
Middleton, B.A., and Jiang, M., 2013, Use of sediment amendments to rehabilitate sinking coastal swamp forests in Louisiana: Ecological Engineering, v. 54, p. 183-191.

Middleton, B.A., Johnson, D., and Roberts, B.J., 2015, Hydrologic remediation for the Deepwater Horizon incident drove ancillary primary production increases in coastal swamps: Ecohydrology, v. 8, 838-850.

Middleton, B.A., and Souter, N.J., 2016, Functional integrity of freshwater forested wetlands, hydrologic alteration, and climate change: Ecosystem Health and Sustainability, v. 2, e01200.

Mitsch, W.J., Taylor, J.R., and Benson, K.B., 1991, Estimating primary productivity of forested wetland communities in different hydrologic landscapes: Landscape Ecology, v. 5, p. $75-92$.

Montz, G.N., and Cherubini, A., 1973, An ecological study of a baldcypress swamp in St. Charles Parish, Louisiana: Castanea, v. 38, p. 378-386.

Morris, J.T., and Bradley, P.M., 1999, Effects of nutrient loading on preservation of organic carbon in wetland sediments: Limnology and Oceanography, v. 44, p. 699-702.

Morris, J.T., Shaffer, G.P., and Nyman, J.A., 2013a, Perspectives on the influence of nutrients on the sustainability of coastal wetlands: Wetlands, v. 33, p. 975-988.

Morris, J.T., Sundberg, K., and Hopkinson, C.S., 2013b, Salt marsh primary production and its response to relative sea level rise and nutrients in estuaries at Plum Island, Massachusetts, and North Inlet, South Carolina, USA: Oceanography, v. 26 , p. $78-84$.

Morton, R.A., Bernier, J.C., Barras, J.A., and Ferina, N.F., 2005, Historical subsidence and wetland loss in the Mississippi Delta Plain: Gulf Coast Association of Geological Societies Transactions, v. 55, p. 555-571.

Muneepeerakul, C.P., Miralles-Wilhelm, F., Tamea, S., Rinaldo, A., Rodriguez-Iturbe, I., 2008, Coupled hydrologic and vegetation dynamics in wetland ecosystems: Water Resources Research, v. 44, W07421.

Myers, R.S., Shaffer, G.P., and Llewellyn, D.W., 1995, Baldcypress (Taxodium distichum (L.) Rich.) restoration in southeast Louisiana-The relative effects of herbivory, flooding, competition, and macronutrients: Wetlands, v. 15, p. 141-148.

National Oceanic and Atmospheric Administration (NOAA), 2015, Tides \& Currents, mean sea level trend, Grand Isle, Louisiana: Accessed March 23, 2015, at http://tidesandcurrents. noaa.gov/sltrends/sltrends_station.shtml?id=8761724. 
Noe, G.B., Hupp, C.R., and Rybicki, N.B., 2013, Hydrogeomorphology influences soil nitrogen and phosphorus mineralization in floodplain wetlands: Ecosystems, v. 16, p. 75-94.

Nyman, J.A., 2014, Integrating successional ecology and the delta lobe cycle in wetland research and restoration: Estuaries and Coasts, v. 37, p. 1490-1505.

Nyman, J.A., Walters, R.J., DeLaune, R.D., and Patrick, W.H., Jr., 2006, Marsh vertical accretion via vegetative growth: Estuarine, Coastal and Shelf Science, v. 69, p. 370-380.

Odum, E.P., Finn, J.T., and Franz, E.H., 1979, Perturbation theory and the subsidy-stress gradient: BioScience, v. 29, p. 349-352.

Osland, M.J., Spivak, A.C., Nestlerode, J.A., Lessmann, J.M., Almario, A.E., Heitmuller, P.T., Russell, M.J., Krauss, K.W., Alvarez, F., Dantin, D.D., Harvey, J.E., From, A.S., Cormier, N., and Stagg, C.L., 2012, Ecosystem development after mangrove wetland creation: plant-soil change across a 20-year chronosequence: Ecosystems, v. 15, p. 848-866.

Patrick, W.H., Jr., and Khalid, R.A., 1974, Phosphate release and sorption by soils and sediments: effects of aerobic and anaerobic conditions: Science, v. 186, p. 53-55.

Penfound, W.T., and Hathaway, E.S., 1938, Plant communities in the marshlands of southeastern Louisiana: Ecological Monographs, v. 8, p. 1-56.

Penland, S., Ramsey, K.E., McBride, R.A., Mestayer, J.T., and Westphal, K.A., 1988, Relative sea-level rise and delta-plain development in the Terrebonne Parish region: Baton Rouge, Louisiana Geological Survey, Coastal Geology Technical Report No. 4, 121 p.

Pezeshki, S.R., 1987, Gas exchange response of tupelo-gum (Nyssa aquatica L.) to flooding and salinity: Photosynthetica, v. 21, 489-493.

Pezeshki, S.R., 1990, A comparative study of the response of Taxodium distichum and Nyssa aquatica seedlings to soil anaerobiosis and salinity: Forest Ecology and Management, v. 33/34, p. 531-541.

Pezeshki, S.R., DeLaune, R.D., and Patrick, W.H. Jr., 1987, Response of baldcypress (Taxodium distichum L. var. distichum) to increases in flooding salinity in Louisiana's Mississippi River Deltaic Plain: Wetlands, v. 7, p. 1-10.

Pezeshki, S.R., DeLaune, R.D., and Patrick, W.H. Jr., 1990, Flooding and saltwater intrusion-Potential effects on survival and productivity of wetland forests along the U.S. Gulf Coast: Forest Ecology and Management, v. 33/34, p. 287-301.
Pezeshki, S.R., Patrick, W.H., Jr., DeLaune, R.D., and Moser, E.D., 1989, Effects of waterlogging and salinity interactions on Nyssa aquatica seedlings: Forest Ecology and Management, v. 27, p. 41-51.

Priest, B., 2011, Effects of elevation and nutrient availability on the primary production of Spartina alterniflora and the stability of southeastern coastal salt marsh relative to sea level: Columbia, University of South Carolina, M.S. thesis.

Putnam, J.A., Furnival, G.M., and McKnight, J.S., 1960, Management and inventory of southern hardwoods: Washington, D.C., U.S. Department of Agriculture, Forest Service, Agricultural Handbook 181, 102 p.

Rapport, D.J., Costanza, R., and McMichael, A.J., 1998, Assessing ecosystem health: Trends in Ecology and Evolution, v. 13, p. 397-402.

Ravit, B., Ehrenfeld, J., Haggblom, M., and Bartels, M., 2007, The effects of drainage and nitrogen enrichment on Phragmites australis, Spartina alterniflora and their root-associated microbial communities: Wetlands, v. 27, p. 915-927.

Redfield, A.C., 1958, The biological control of chemical factors in the environment: American Scientist, v. 46, p. 205-222.

Reineke, L.H., 1933, Perfecting a stand density index for even aged forests: Journal of Agricultural Research, v. 46, p. 627-638.

Renschler, C.S., Flanagan, D.C., Engel, B.A., Kramer, L.A., and Sudduth, K.A., 2002, Site-specific decision making based on RTK GPS survey and six alternate elevation data sources: watershed topography and delineation: Transactions of the American Society of Agricultural and Biological Engineers, v. 45, p. 1883-1895.

Ritchie, J.C., Zimba, P.V., and Everitt, J.H., 2003, Remote sensing techniques to assess water quality: Photogrammetric Engineering \& Remote Sensing, v. 69, p. 695-704.

Rivera-Monroy, V.H., Branoff, B., Meselhe, E., McCorquodale, A., Dortch, M., Steyer, G.D., Visser, J., and Wang, H., 2013, Landscape-level estimation of nitrogen removal in coastal Louisiana wetlands-Potential sinks under different restoration scenarios: Journal of Coastal Research, v. SI 67, p. $75-87$.

Rybczyk, J.M., Callaway, J.C., and Day, J.W., Jr., 1998, A relative elevation model for a subsiding coastal forested wetland receiving wastewater effluent: Ecological Engineering, v. 112, p. $23-44$. 
Rybczyk, J.M., Day, J.W., Jr., and Conner, W.H., 2002, The impact of wastewater effluent on accretion and decomposition in a subsiding forested wetland: Wetlands, v. 22, p. $18-32$.

Salinas, L.M., DeLaune, R.D., and Patrick, W.H., Jr., 1986, Changes occurring along a rapidly subsiding coastal area-Louisiana, USA: Journal of Coastal Research, v. 2, p. 269-284.

Scott, D.T., Keim, R.F., Edwards, B.L., Jones, C.N., and Kroes, D.E., 2014, Floodplain biogeochemical processing of floodwaters in the Atchafalaya River Basin during the Mississippi River flood of 2011: Journal of Geophysical Research Biogeosciences, v. 119, p. 537-546.

Shaffer, G.P., Day, J.W., Jr., Hunter, R.G., Lane, R.R., Lundberg, C.J., Wood, W.B., Hillmann, E.R., Day, J.N., Strickland, E., and Kandalepas, D., 2015, System response, nutria herbivory, and vegetation recovery of a wetland receiving secondarily-treated effluent in coastal Louisiana: Ecological Engineering, v. 79, p. 120-131.

Shaffer, G.P., Day, J.W., Jr., Kandalepas, D., Wood, W.B., Hunter, R.G., Lane, R.R., and Hillmann, E.R., 2016, Decline of the Maurepas Swamp, Pontchartrain Basin, Louisiana, and approaches to restoration: Water, v. 8, w8030101.

Shaffer, G.P., Day, J.W., Jr., Mack, S., Kemp, G.P., van Heerden, I., Poirrier, M.A., Westphal, K.A., FitzGerald, D., Milanes, A., Morris, C.A., Bea, R., and Penland, P.S., 2009b, The MRGO navigation project - A massive humaninduced environmental, economic, and storm disaster: Journal of Coastal Research, v. SI 54, p. 206-224.

Shaffer, G.P., Wood, W.B., Hoeppner, S.S., Perkins, T.E., Zoller, J., and Kandalepas, D., 2009a, Degradation of baldcypress-water tupelo swamps to marsh and open water in southeastern Louisiana, U.S.A.-An irreversible trajectory: Journal of Coastal Research, v. SI 54, p. 152-165.

Shaw, J.B., Mohrig, D., and Whitman, S.K., 2013, The morphology and evolution of channels on the Wax Lake Delta, Louisiana, USA: Journal of Geophysical Research Earth Surface, v. 118, p. 1562-1584.

Shipley, B., and Meziane, D., 2002, The balanced-growth hypothesis and the allometry of leaf and root biomass allocation: Functional Ecology, v. 16, p. 326-331.

Stagg, C.L., Krauss, K.W., Cahoon, D.R., Cormier, N., Conner, W.H., and Swarzenski, C.M., 2016, Processes contributing to resilience of coastal wetlands to sea-level rise: Ecosystems, v. 19, no. 8, p. 1445-1459.

Stagg, C.L., and Mendelssohn, I.A., 2010, Restoring ecological function to a submerged salt marsh: Restoration Ecology, v. 18, p. 10-17.
State of Louisiana, 1993, Louisiana coastal wetlands restoration plan-Main report and environmental impact statement: Louisiana Coastal Wetlands Conservation and Restoration Task Force, accessed March 24, 2015, at http://lacoast.gov/reports/cwcrp/1993/1993lcwrp-2introsolutions.pdf.

State of Louisiana, 2012, Louisiana's comprehensive master plan for a sustainable coast: Baton Rouge, State of Louisiana, Coastal Protection and Restoration Authority, 190 p.

State of Louisiana, 2014, Mississippi River reintroduction into Maurepas Swamp: Baton Rouge, State of Louisiana, Coastal Protection and Restoration Authority, RESTORE Act proposal, $32 \mathrm{p}$.

Stevenson, M.J., and Day, F.P., 1996, Fine-root biomass distribution and production along a barrier island chronosequence: American Midland Naturalist, v. 135, p. 205-217.

Steyer, G.D., Sasser, C.E., Visser, J.M., Swenson, E.M., Nynam, J.A., and Raynie, R.C., 2003, A proposed coastwide reference monitoring system for evaluating wetland restoration trajectories in Louisiana: Environmental Monitoring and Assessment, v. 81, p. 107-117.

Swarzenski, C.M., Doyle, T.W., Fry, B., and Hargis, T.G., 2008, Biogeochemical response of organic-rich freshwater marshes in the Louisiana delta plain to chronic river water influx: Biogeochemistry, v. 90, p. 49-93.

Thom, R.M., 2000, Adaptive management of coastal ecosystem restoration projects: Ecological Engineering, v. 15, p. $365-372$.

Tockner, K., Pennetzdorfer, D., Reiner, N., Schiemer, F., and Ward, J.V., 1999, Hydrological connectivity, and the exchange of organic matter and nutrients in a dynamic riverfloodplain system (Danube, Austria): Freshwater Biology, v. 41, p. 521-535.

Toner, M., and Keddy, P, 1997, River hydrology and riparian wetlands: a predictive model for ecological assembly: Ecological Applications, v. 7, p. 236-246.

Törnqvist, T.E., González, J.L., Newsom, L.A., van der Borg, K., de Jong, A.F.M., and Kurnik, C.W., 2004, Deciphering Holocene sea-level history on the U.S. Gulf Coast-A highresolution record from the Mississippi Delta: Geological Society of America Bulletin, v. 116, p. 1026-1039.

Turner, R.E., 2010, Beneath the salt marsh canopy-Loss of soil strength with increased nutrient loads: Estuaries and Coasts, v. 34, p. 1084-1093.

Turner, R.E., Howes, B.L., Teal, J.M., Milan, C.S., Swenson, E.M., and Goehringer-Toner, D.D., 2009, Salt marshes and eutrophication - An unsustainable outcome: Limnology and Oceanography, v. 54, p. 1634-1642. 
Valiela, I., Teal, J.M. and Persson, N.Y., 1976, Production and dynamics of experimentally enriched salt marsh vegetation-Belowground biomass: Limnology and Oceanography, v. 21, p. 245-252.

Waring, R.H., and Running, S.W., 2010, Forest ecosystemsAnalysis at multiple scales: Burlington, Massachusetts, Elsevier Academic Press.

Webb, E.L., Friess, D.A., Krauss, K.W., Cahoon, D.R., Guntenspergen, G.R., and Phelps, J., 2013, A global standard for monitoring coastal wetland vulnerability to accelerated sea-level rise: Nature Climate Change, v. 3, p. 458-465.

Whelan, K.R.T., Smith, T.J. III, Cahoon, D.R., Lynch, J.C., and Anderson, G.H., 2005, Groundwater control of mangrove surface elevation-Shrink and swell varies with soil depth: Estuaries, v. 28, p. 833-843.

Wicker, K.M., Davis, D., DeRouen, M., and Roberts, D., 1981, Assessment of extent and impact of saltwater intrusion into the wetlands of Tangipahoa Parish, Louisiana: Baton Rouge, Louisiana, Coastal Environments Inc.

Wigand, C., Brennan, P., Stolt, M., Holt, M., and Ryba, S., 2009, Soil respiration rates in coastal marshes subject to increasing watershed nitrogen loads in southern New England, USA: Wetlands, v. 29, p. 952-963.

Wilcox, D.A., Meeker, J.E., Hudson, P.L., Armitage, B.J., Black, M.G., and Uzarski, D.G., 2002, Hydrologic variability and the application of index of biotic integrity metrics to wetlands-A Great Lakes evaluation: Wetlands, v. 22, p. 588-615.
Wilhite, L.P., Toliver, J.R., 1990, Taxodium distichum (L.) Rich. baldcypress, in Burns, R.M., Honkala, B.H., tech. coords., Silvics of North America, v. 1, Conifers: Washington, D.C., U.S. Department of Agriculture, Agricultural Handbook 654, p. 563-572.

Willard, D.A., Bernhardt, C., Brown, R., Landacre, B., and Townsend, P., 2010, Development and application of a pollen-based paleohydrologic reconstruction from the Lower Roanoke River Basin, North Carolina, USA: The Holocene, v. 21, p. 305-317.

Willard, D.A., Cronin, T.M., and Verardo, S., 2003, LateHolocene climate and ecosystem history from Chesapeake Bay sediment cores, USA: The Holocene, v. 13, p. 201-214.

Wood, W.B., Shaffer, G.P., Visser, J.M., Krauss, K.W., Piazza, S.C., Sharp, L.A., and Cretini, K.F., 2017, Forested Floristic Quality Index-An assessment tool for forested wetland habitats using the quality and quantity of the woody vegetation present at Coastwide Reference Monitoring System (CRMS) vegetation monitoring stations: U.S. Geological Survey Open-File Report 2017-1002, 15 p., accessed April 4, 2017, at https://doi.org/10.3133/ofr20171002.

Zhang, Y., Wang, L., Xie, X., Huang, L., and Wu, Y., 2013, Effects of invasion of Spartina alterniflora and exogenous $\mathrm{N}$ deposition on $\mathrm{N}_{2} \mathrm{O}$ emissions in a coastal salt marsh: Ecological Engineering, v. 58, p. 77-83. 


\section{Appendix 1. Current Plot and Data Availability of Potential Relevance for Future Monitoring}

\begin{abstract}
Maurepas Swamp, Louisiana, is characterized by nutrient-poor waters with nitrate $\left(\mathrm{NO}_{3}^{-}\right)$concentrations less than 1 percent of those found in the Mississippi River (Lane and others, 2003; Day and others, 2004). In addition, Maurepas Swamp soils are of extremely low strength (Shaffer and others, 2003), and the mean salinity of Lake Maurepas water measured at Pass Manchac has been affected beginning in the early 1960s by the opening of the Mississippi River-Gulf Outlet Canal (MRGO; Thomson and others, 2002; Shaffer and others, 2009b). The closure of the MRGO in 2009 combined with the future implementation of one or more river reintroductions (diversions) should help to ameliorate some of these stressors. Here, we outline past or current data collection efforts not specifically addressed in sections "PM1: Establishing a Hydrologic Regime Consistent With Swamp Forest Sustainability" through "PM5: Facilitating Nutrient Uptake and Retention" but that may provide relevant information for monitoring of a proposed Mississippi River reintroduction into the forested wetlands of Maurepas Swamp.
\end{abstract}

\section{Permanent Forested Wetland Study Plots}

Shaffer and others (2009a), with Southeastern Louisiana University, initiated a study in 2000 in which 20 plots were established with paired 625-square meter $\left(\mathrm{m}^{2}\right)$ stations (40 stations) to capture three habitat types characterized by different hydrologic regimes in Maurepas Swamp: (1) relict: stagnant, nearly permanently flooded interior plots, characterized by trees with broken canopies, few midstory species, and a welldefined herbaceous community ("backswamp"); (2) degraded: plots near Lake Pontchartrain or the margin of Lake Maurepas that are prone to severe saltwater intrusion events, characterized by dead trees, sparsely populated by Taxodium distichum (baldcypress), and dominated by herbaceous species and open water; and (3) throughput: plots receiving reliable nonpoint sources of freshwater runoff, characterized by mature overstory and midstory stands and little herbaceous cover (fig. 1-1). The relict, degraded, and throughput plots characterize an area of roughly 80 square kilometers $\left(\mathrm{km}^{2}\right)$ and were replicated to reflect the relative proportion of each habitat type that coincidentally may receive restored water flows from a Mississippi River reintroduction. In addition, four additional plots with paired $625-\mathrm{m}^{2}$ stations (fig. 1-1) (eight additional stations) were installed in 2004 to provide baseline conditions for a levee-gapping project on the Amite River Diversion Canal begun in 2016.
Annually, from 2000 through 2010, net primary production (NPP) of more than 2,000 trees and nearly 100 herbaceous subplots was measured, as well as a number of abiotic variables, with soil bulk density, interstitial soil salinity, and light penetration being the most important. Detailed methods for the 2000-2006 portion of the study were provided by Shaffer and others (2009a), and the methods remained the same through 2010. These baseline data captured the effects of severe droughts (2000 and 2006), normal weather conditions, and the hurricanes of 2002, 2005, and 2008, which may be critical for separating out the influences of periodic disturbances from other changes related to a river reintroduction (see Conner and others, 2014).

\section{Net Primary Production}

The single best integrator of ecosystem function is NPP, perhaps followed by natural regeneration, which requires very specific environmental conditions and may not occur early in the restoration process. The most difficult and time-consuming aspect of obtaining NPP for each of the 48 stations (Shaffer and others, 2009a) was the herbaceous layer. Sampling involves taking four clip plots at each station during spring and again during late fall. The spring and fall clip plots are added together because a turnover study in Maurepas Swamp (Shaffer and others, 2009a) indicated that one of the dominant species, Sagittaria lancifolia (bulltongue), replaced its original tissue once during the year. The first dead leaf occurred in May, and the entire individual replaced all of the original leaves by the following October. Because the major objective of a river reintroduction into Maurepas Swamp is reassembly to a healthy habitat type and healthy site NPP is nearly completely dominated by tree species, only a small portion of error will be added to total station NPP by ignoring herbaceous species ground cover.

Moreover, there are several other variables that can be used to determine the degree of habitat reassembly from open to closed canopy forest condition: soil bulk density, light penetration, stand density and floristic quality indices, tree height, and basal area all separate crisply by habitat type (Shaffer and others, 2016). Wood and litterfall production, along with the aforementioned variables, measured at many plots located at various distances from the diversion structure outfall, should tightly capture project benefits. In addition, the studies have captured the habitat types through changes in signature of satellite and aerial photography (for example, fig. 2). 


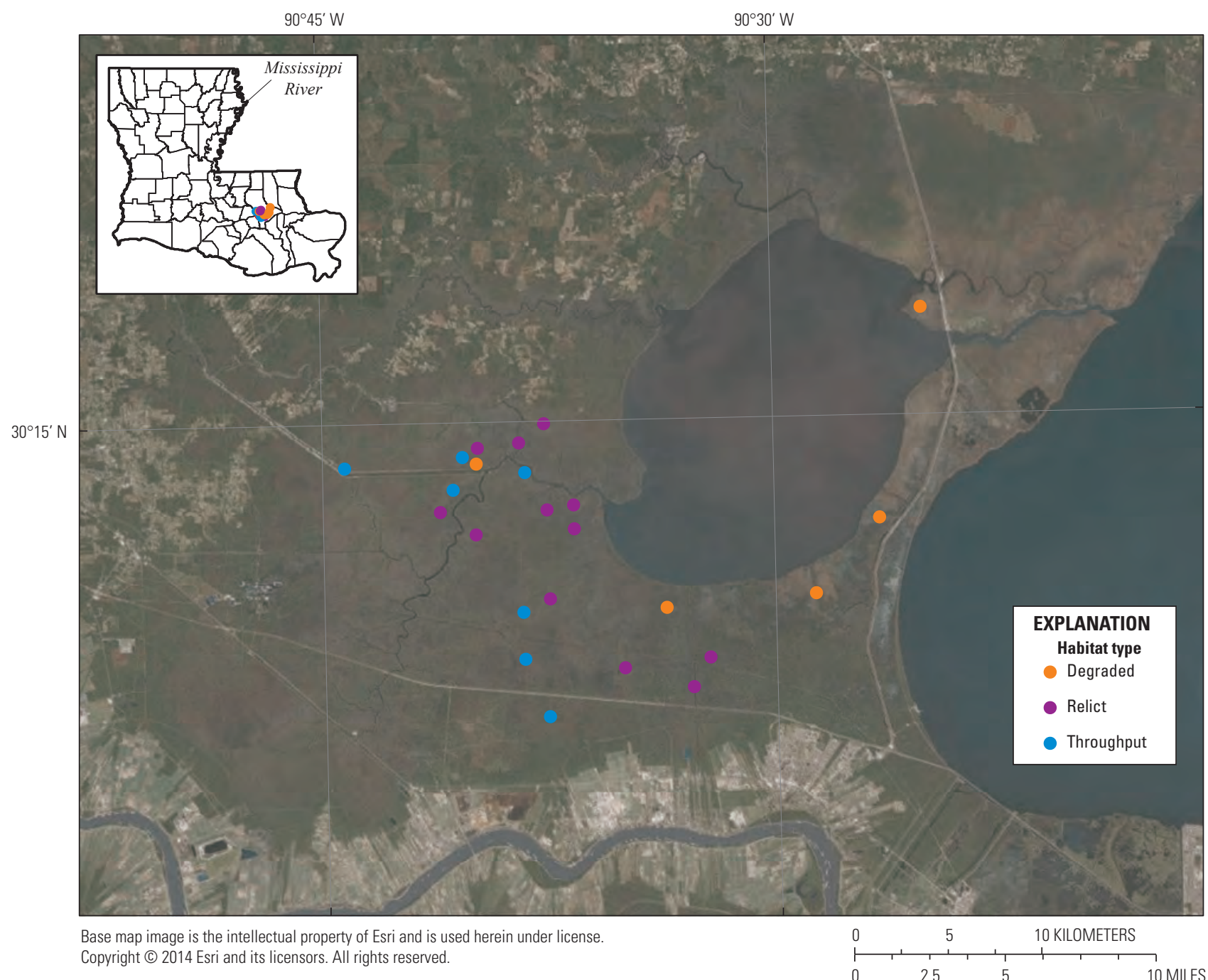

Figure 1-1. Locations of 24 plots, each with paired 625-square-meter stations (48 stations total), selected to represent the three major habitat types characterized by different hydrologic regimes in Maurepas Swamp, Louisiana: throughput, relict, and degraded.

Along with these 24 plots and 48 permanent $625-\mathrm{m}^{2}$ sampling stations, Maurepas Swamp and immediate surroundings also have 25 Coastwide Reference Monitoring System (CRMS) stations (Steyer and others, 2003; Folse and others, 2014); there are 11 CRMS stations in the proposed Mississippi River reintroduction project area. Measurements are made for the following variables at each CRMS station and at the following time schedules:

- hourly: surface water salinity and temperature, and stage;

- monthly: soil pore water (this collection is highly variable and is done whenever the station is visited);

- biannually: surface elevation table and accretion plots where feasible (very limited in the swamp);
- annually: herbaceous vegetation cover and height, density of the canopy in overstory plots;

- every 3 years: diameter at breast height (DBH) of all living trees with DBH greater than 5 centimeters $(\mathrm{cm})$ (trees are tagged for tracking over years), height and DBH of living shrubs and trees in the midstory with DBH less than $5 \mathrm{~cm}$;

- every 5 years: soil cores for percent organic content and bulk density along with soil salinity (actually 2008 and 2014) and percent land:water analysis if photography is available (actually 2008, 2012, and 2015).

All 25 Maurepas Swamp CRMS stations are located in edge habitat, and edge habitat does not undergo the same environmental conditions as does the interior swamp. Nearly all edges in Maurepas Swamp are vividly healthier than their corresponding interiors. 


\section{Soil Surface Elevation Change}

Surface elevation change in coastal wetlands is often measured by using a surface elevation table (SET). A SET includes a pipe or rod inserted either to a specific depth into the soil or to a point of refusal (see Callaway and others, 2013, for a comprehensive review). More recently, refusal depths using the modified rod SET have corresponded to the standard imposed by the U.S. National Geodetic Survey (NGS), making comparisons with tide gages more direct. Sedimentation marker horizons (MHs) are often deployed alongside SETs (known as the SET-MH method; Cahoon and others, 1999) to track vertical accretion of sediments simultaneously with surface elevation change, thus providing insight into how much of the surface elevation change can be explained by accretion of sediments, shallow subsidence, or soil volume expansion (Cahoon and others, 1999; McKee and others, 2007).

In 2003, at a relatively healthy location near the confluence of Little Bayou Chene Blanc and Blind River (Shaffer and others, 2009a), 12 SET-MH plots were installed, each approximately 3 meters $(\mathrm{m})$ from the bole of a mature baldcypress. Each SET was outfitted with a 3-m by 3-m platform for taking undisturbed measurements (Cahoon and others, 1999). The area within each platform received one of three treatments: four plots received no treatment, four received 11.25 grams $(\mathrm{g})$ of nitrogen $(\mathrm{N})$ per square meter per year $\left(\mathrm{m}^{-2} \mathrm{yr}^{-1)}\right.$ of 18-6-12 time-released fertilizer to simulate the loading rate of a 42.5 cubic meters per second $\left(\mathrm{m}^{3} / \mathrm{s}\right)$ river reintroduction into Maurepas Swamp (Day and others, 2004) during spring, and four received $11.25 \mathrm{~g} \mathrm{~N} \mathrm{~m}^{-2} \mathrm{yr}^{-1}$ fertilizer plus $1 \mathrm{~cm}$ of Bonnet Carré Floodway silt to simulate sites located more proximal to a river reintroduction (Shaffer and others, 2016). The treatments were applied annually through 2008. SET measurements were taken in 2003 and again in 2008.

Besides the 12 SETs installed in 2003 for the river reintroduction simulation study, other SET plots were installed in 2000 at 11 additional locations. MHs were installed as well (Cahoon and others, 1999), but no MHs have been found during subsequent site visits because of feldspar migration through soils of low bulk density and strength. Measurements were taken annually from 2001 to 2005 and again in 2010. Thus far, the variability in the data is high, so clear trends in soil surface elevation change are difficult to discern. Nevertheless, new measurements for all of these SETs may be taken periodically because the true elevation change signature will register above the noise at some point in time.

Finally, of the 11 CRMS stations in the Mississippi River reintroduction into Maurepas Swamp project area, acceptable records of wetland surface elevation change $\left(\mathrm{VLM}_{\mathrm{w}}\right.$; Cahoon, 2015) data were obtained from SETs positioned on nine of the CRMS stations. These stations crossed habitat types from closed forest canopy to open canopy wetland. To be included, stations had to have no more than 1 year of missing data; however, stations not meeting this criterion typically had many missing years of data because of permanent flooding.

\section{Artificial Regeneration Efforts}

Success of artificial plantings can often help to identify whether lands previously having trees are still able to support forests. Several independent attempts were conducted in the Pass Manchac-Lake Maurepas area by researchers at Southeastern Louisiana University, Louisiana State University, and the Lake Pontchartrain Basin Foundation (LPBF) to convert degraded marsh back into baldcypress forest. In the early 1990s, ten thousand seedlings were planted on the land bridge between Lakes Maurepas and Pontchartrain (Myers and others, 1995). Survival was high (77 percent) until a drought in 1999 that resulted in salinities as high as 9 practical salinity units (psu); most of the seedlings were killed, even though many had been exposed to nearly constant 2.8 psu salinities before the drought with good survival (Myers and others, 1995). In 1998, a baldcypress mitigation bank was established on Jones Island, located on the eastern edge of Lake Maurepas. Thirty-six thousand seedlings were planted. Saltwater intrusion in 1999 and 2000 caused near complete mortality, and the area was replanted. Survival was high until Hurricanes Katrina and Rita brought salinities as high as 5.5 psu to the area for a 2-month period, resulting again in near complete mortality. That mitigation effort was subsequently abandoned. Even in times with lower salinities, herbivory by the introduced rodent Myocastor coypus (nutria) has been high and has severely limited survival of young baldcypress in Louisiana (Conner and others, 1986), including throughout Maurepas Swamp (Myers and others, 1995) and even on additional attempts to reestablish baldcypress on Jones Island on a smaller scale (in 2005; R.S. Effler and R.A. Goyer, Louisiana State University, unpub. data, 2015).

In the early 1990s, a study was initiated to determine the effectiveness of various treatments to control nutria herbivory of baldcypress seedlings, such as Tanglefoot (that is, a "sticky, non-drying, biodegradable, and water resistant castor oil based material"; p. 144, Myers and others, 1995) and plastic sleeves varying from mesh to PVC (Myers and others, 1995). Unprotected seedlings suffered 100 percent mortality, as did those protected with mesh sleeves. Tanglefoot was effective, but only for 1 year. In addition, fertilizer doubled seedling growth, as it did in several other factorial studies (Greene, 1994; Boshart, 1997; Effler and others, 2006; Shaffer and others, 2009a). Recently, the LPBF planted eleven thousand seedlings during the winter of 2014 and 2015, and an additional thirteen thousand five hundred seedlings over the next two winters on the land bridge between Lakes Maurepas and Pontchartrain, and these seedlings have been monitored for survivorship since spring 2016 (Henkel and others, 2017). To date, survival of these seedlings has been high, at approximately 87 percent, and the presence of tree saplings in the understory indicates recent natural regeneration, attributed to salinity reductions and reduced variability around reduced salinities since the closure of the MRGO (Henkel and others, 2017). 
In 2006 the City of Hammond completed construction of a 15.1 million liters per day (4 million gallons per day) assimilation wetland in the Joyce Wildlife Management Area located just south of Ponchatoula, Louisiana (hereinafter referred to as the "Hammond assimilation wetland"). Baldcypress seedling growth was highest near the outfall system and decreased linearly with distance from the outfall, as did nutrient concentrations (Lundberg, 2008; Lundberg and others, 2011; Shaffer and others, 2015). Initially, herbaceous vegetation production doubled near the outfall system, but the marsh disappeared by late spring 2008 (Shaffer and others, 2015). A series of hypotheses were tested, and it was determined that, again, nutria were primarily responsible for the marsh degradation (Shaffer and others, 2015). More than 2,000 nutria were culled from the area, and the marsh has substantially recovered, especially in areas nearest to the outfall system (G.P. Shaffer, unpub. data, 2015). Baldcypress seedlings and mature trees near the outfall system are growing fivefold to tenfold faster than anywhere else in Maurepas Swamp (Shaffer and others, 2015).

Finally, more than 900 baldcypress seedlings were planted in small light gaps along a hydrologic gradient in Maurepas Swamp to test assumptions associated with a regeneration condition class designation developed for coastal Louisiana forested wetlands (Chambers and others, 2005). Rutherford (2015) discovered that survival of baldcypress was relatively high along the hydrologic gradient, but survival and growth were both dependent upon seedling height at planting and the degree of submergence the seedlings underwent; some sites with smaller seedlings had survival rates of only 9 percent after 90 cumulative days of flooding. Most survival was far greater than 9 percent, and there was little sign of nutria impacts to plantings established in existing understories. Seedling size at planting and degree of submergence are yet additional issues relating to the difficulty of planting trees where forests have degraded and marshes dominate (Rutherford, 2015).

Thomson and others (2002), through use of local tide gage data, demonstrated that flooding has doubled in Maurepas Swamp since 1955 because of a combination of sealevel rise and subsidence, suggesting that the extreme case of low survival reported by Rutherford (2015) may not be uncommon in the future without measures to offset submergence. Thomson (2000) also showed that placing weirs on baldcypress logging ditches decreased marsh NPP because it decreases tidal exchange, the chronic condition faced by much of Maurepas Swamp currently. A reciprocal transplant study between an oligohaline and mesohaline marsh revealed that interstitial salinity and sulfide levels were primary drivers of the transition from oligohaline to mesohaline marsh plant communities, with this transition expedited by disturbance (Kaller, 2003).

\section{Hydrology and Salinity Changes}

Before major human-induced physical alterations to the landscape, the Orleans and St. Bernard Parish wetlands were divided into three interdistributary basins formed by natural levee ridges of former Mississippi River distributaries: Bayou Sauvage, Bayou Terre aux Boeufs, and Bayou la Loutre (Wicker and others, 1982). The environment was stable because of a general sheet flow pattern of freshwater from rainfall, drainage pump stations, and other sources, which was slowed and stored by wetland vegetation. Furthermore, the Bayou la Loutre ridge helped to retain freshwater and prevent saltwater intrusion from Breton Sound. In addition, saltwater from Breton Sound was (and is) freshened by influences from the Pearl River and other local rivers that deliver freshwater through Lake Pontchartrain into Lake Borgne. Therefore, historical water levels and salinity changed very gradually with rainfall and tidal conditions.

The U.S. Fish and Wildlife Service (USFWS) determined, prior to construction, that detailed studies were needed to fully understand the effect of the planned MRGO on fish and wildlife resources. The USFWS became the coordinating agency for extensive and detailed preconstruction hydrologic and biological studies to facilitate discussions with the U.S. Army Corps of Engineers to minimize channel effects on the environment and wildlife. Most of the hydrologic studies were under contract with the Texas A\&M Research Foundation. Some of the studies include El-Sayed (1961) and Amstutz (1964). The studies addressed the interaction and exchange between subareas, existing variations in hydrology to enable forecasting of extremes in variation due to the planned project, and sampling of aquatic fauna and hydrology to consider the potential biological effects of environmental changes due to the project.

One of the most detailed hydrologic studies (Rounsefell, 1964) was conducted from April 1959 to March 1961 to detail the pre-MRGO hydrology. Salinity, dissolved oxygen, water temperature, inorganic phosphate $\left(\mathrm{PO}_{4}^{-3}\right)$ concentration, and turbidity were sampled several times a month throughout the area (Rounsefell, 1964). The conclusion of the study was that very little saline water entered Lake Borgne from Breton Sound, specifically because of the Bayou la Loutre ridge acting as a barrier between Lake Borgne and Breton Sound. This ridge, in combination with the freshwater surplus of the area now occupied by the "Central Wetlands Unit," kept salinities low enough to allow the baldcypress-Nyssa aquatica (water tupelo) swamps to survive prior to the construction of the MRGO. Based on the Texas A\&M Research Foundation studies, Rounsefell (1964) further concluded that changes in salinity patterns and population structure of estuarine organisms would result from the construction of the MRGO. 
Through its connection to the Inner Harbor Navigation Canal (IHNC), the MRGO provided a direct linkage between the low-salinity waters of Lake Pontchartrain and the highsalinity waters of Breton Sound. The MRGO delivered saltwater to the lake. The salt sank and caused the water column to stratify. Differences between mean surface and bottom water salinity exceeded 10 psu (Poirrier, 1978; Junot and others, 1983), even though the average salinity of Lake Pontchartrain was only 3.9 psu (Sikora and Kjerfve, 1985; Francis and others, 1994). The stratification led to episodic events of low dissolved oxygen (hypoxia and anoxia) that killed sessile creatures such as the clam Rangia cuneata (Poirrier and others, 2009). Because of saltwater intrusion from the MRGO, roughly $259 \mathrm{~km}^{2}$ (100 square miles) of the lake's benthos was nearly devoid of life (Poirrier, 1978; Abadie and Poirrier, 2001; Poirrier and others, 2001; Spalding and others, 2006). The saltwater from the MRGO caused hypoxic conditions to occur as far north as 24 kilometers $(\mathrm{km})$ from the mouth of the IHNC (Spalding and others, 2006). Earlier studies (Sikora and Sikora, 1982) attributed the depauperate benthic community in the dead zone to chemical spills and urban runoff. Later investigations (Poirrier and others, 1984; Powers and others, 1992) revealed that the effects of urban runoff were localized and that the cause for episodic hypoxic and anoxic bottom waters in the larger dead zone was saltwater intrusion from the MRGO (McCorquodale and Georgiou, 2002).

Ecologically, the episodic anoxic bottom waters caused by saltwater delivery through the MRGO decimated populations of $R$. cuneata, which decreased the health of the entire aquatic ecosystem of Lakes Pontchartrain and Maurepas.

Rangia cuneata filters silts, clays, algae, and bacteria from the water column, increasing water clarity. The shells of $R$. cuneata stabilize the benthos and the shell hash (that is, remnants) help to stabilize shorelines; $R$. cuneata add about 700,000 metric tons of shell annually to bottom sediments and serve as a food source for fish, crabs, and waterfowl (Spalding and others, 2006). It was estimated that restoration of the hypoxic zone, through closure of the MRGO in 2009, would increase light penetration on the north shore waters of Lake Pontchartrain from $2.0 \mathrm{~m}$ to $2.4 \mathrm{~m}$ and on the south shore waters from $0.6 \mathrm{~m}$ to $1.3 \mathrm{~m}$ (Poirrier and Spalding, 2004). As a result, submerged aquatic vegetation (SAV) would be expected to increase in areal coverage by as much as 685 hectares (Poirrier and Spalding, 2004; Cho and Poirrier, 2005). SAV provides refugia for breeding and juvenile fish, increases sedimentation and therefore water clarity, stabilizes sediments, decreases wave energy, and provides food for waterfowl and detritivores. Combined, $R$. cuneata and SAV provide a feedback to increased ecosystem health; this loop was crippled by the MRGO (Poirrier and Spalding, 2004) and is likely to reestablish now that the MRGO has been closed.

\section{Mercury}

The total mercury concentrations in soils and plant tissues, as well as the methyl mercury concentrations in soils, determined within the Lake Maurepas and associated wetlands appear to be within the range of those for normal, uncontaminated oligohaline wetlands. Hall and others (2008) generally found that freshwater and brackish wetlands in the Lake Pontchartrain Basin (for example, Blind River and Lacombe Bayou), however, have elevated surface water methyl mercury levels compared with the surface waters of Pass Manchac and Lake Pontchartrain.

\section{Fisheries}

Large species shifts in fisheries of Lake Pontchartrain occurred between 1954 and 2000 (Darnell, 1958; O'Connell and others, 2004). One major shift includes a large increase in the population size of Anchoa mitchilli (bay anchovy) attributable to salinity increases caused by the delivery of saltwater through the MRGO. The fishes of Lake Maurepas are generally poorly studied, but a checklist of species was provided by Millican and others (1984). Furthermore, Hastings and others (1987) provided data on relative abundance of fishes, and Fox and others (2007) sampled freshwater fish at 20 locations in interior bayous approximately along the projected flow path of the proposed Mississippi River reintroduction into Maurepas Swamp. Lepisosteus oculatus (spotted gar) and Mugil cephalus (striped mullet) composed 76.5 percent of the total number of fish caught. Species richness was positively related to high dissolved oxygen and low turbidity. Micropterus salmoides (largemouth bass), Lepomis macrochirus (bluegill), and Ictalurus furcatus (blue catfish) were closely associated with the presence of dissolved oxygen along the bottom of surveyed open water areas, a condition likely to be improved upon by a river reintroduction into Maurepas Swamp.

Fox and others (2007) also sampled marine fauna in southern Lake Maurepas. Of the 1,853 individuals caught, they represented 36 fish species and 5 crustacean species. Striped mullet accounted for 39 percent of the catch, Litopenaeus setiferus (white shrimp) 13 percent, bay anchovy 13 percent, and all other species less than 5 percent each of the total catch. One potential negative impact that the river reintroduction could have on fisheries (Fox and others, 2007) is increased abundance of problematic aquatic macrophytes such as Salvinia minima and S. molesta (salvinia), Hydrilla verticillata (hydrilla), and Eichhornia crassipes (water hyacinth).

\section{Ornithological Surveys}

\section{Songbirds}

Protonotaria citrea (prothonotary warblers), Parula americana (northern parula), and Dendroica dominica (yellow-throated warblers) are the most common neotropical 
migratory forest songbirds in Maurepas Swamp (Zoller, 2004; Fox, 2006). Maurepas Swamp is listed as an important bird area at the global scale by the National Audubon Society because of its large populations of prothonotary warblers and northern parulas. A total of 117 bird species were observed on 576 individual point counts, with 6,728 detections (Fox and others, 2007). Mean species richness of neotropical migrant birds was statistically highest at throughput plots (that is, plots with reliable nonpoint sources of freshwater runoff; see section "Permanent Forested Wetland Study Plots"), followed by relict plots, and was lowest at degraded plots (Fox and others, 2007).

Zoller (2004) used weather radar to monitor neotropical bird use of the Lake Maurepas region. The broad patterns of bird movements made it difficult to draw strong inference about land cover associations, as land cover also differs strongly around the lake. Even so, bird abundance was consistently explained best by models that included land cover variables. Bird sightings were more common over closed forest canopy and transitional forest than over open marsh (that is, open canopy wetland), leading to the fundamental conclusion that degradation of swamp forest removes habitat used by migrating birds, and measures to improve swamp health should map directly onto improved neotropical forest songbird habitat.

Two experiments examining the effects of insectivorous birds on tree growth were conducted in degraded areas of Maurepas Swamp (Fox, 2006). In the first experiment, nest boxes were added to study plots in degraded swamp (transitional forest) in an attempt to increase densities of secondary cavity nesting birds and to determine if increased insectivorous bird abundance resulted in improved shoot growth of baldcypress saplings. Prothonotary warblers were the only bird species to utilize the nest boxes, and the nest boxes did significantly increase densities of prothonotary warblers on relict plots, indicating that this habitat type is not saturated with nesting pairs (Zoller, 2004; Fox 2006). In the second experiment, bird exclosures were erected around planted baldcypress and water tupelo seedlings. Leaf damage on trees within bird exclosures and on those with an insecticide treatment was not significantly different from controls.

\section{Bald Eagle}

Haliaeetus leucocephalus (bald eagles) regularly nest in baldcypress near shallow-water areas where they forage. During a nesting survey including most of southeastern Louisiana in the late 1970s, 27 of 29 bald eagle nests were built in baldcypress trees (Harris and others, 1987), highlighting the importance of swamp habitat in the recovery of bald eagle populations. The Louisiana Department of Wildlife and Fisheries conducts annual aerial surveys, revealing that there are now 32 bald eagle nests in Maurepas Swamp alone, 93 percent of which are in large baldcypress (mean height $24.1 \mathrm{~m}$, mean diameter $94.5 \mathrm{~cm}$ ). Seventeen of these nests were active during the 2005-6 season.
The river reintroduction should increase NPP of a portion of Maurepas Swamp, and this increase should lead to increases in secondary production. Without a river reintroduction, the inevitable trajectory of swamp decline (Shaffer and others, 2016) could threaten bald eagle success in Maurepas Swamp. For both the bald eagle and neotropical migratory forest songbirds, Fox and others (2007) suggested that canal construction associated with a river reintroduction should begin in July and be completed prior to January to minimize impacts to these birds.

\section{Colonial Wading Birds}

After several hundred person-hours of surveying, Fox and others (2007) concluded that wading birds inhabit all of the areas that will be affected by a river reintroduction into and through Hope Canal, and into Maurepas Swamp. In addition, a wading bird rookery occurs about $3 \mathrm{~km}$ west of Tobe Canal. This rookery contains 275 Ardea alba (great egret) nests, 50 Ardea herodias (great blue heron) nests, and 11 Anhinga anhinga (anhinga) nests. Furthermore, 10-15 Nyctanassa violacea (yellow-crowned night heron) nests occurred along the eastern shore of Hope Canal during their survey. The authors concluded that short-term disturbance during the construction phase of the river reintroduction engineering and conveyance structures could impact nesting of wading birds but that these impacts should be short lived. Improved habitat will likely occur shortly following the onset of a river reintroduction (Fox and others, 2007).

\section{Herpetology}

For more than 20 years the roads in the Bayou Manchac and Lake Maurepas region have been regularly monitored for the distribution and abundance of several species of snakes (McCardle and others, 2014; McCardle and Fontenot, 2016). The effects of hurricanes on herpetofauna distribution and abundance in this region also have been studied (Schriever and others, 2009), and the wintering behavior of Hyla cinerea (green tree frog) has been documented (Fontenot, 2011). With regard to impacts to Alligator mississippiensis (alligator), Fox and others (2007) concluded that increased water levels near the outfall area of a river reintroduction could decrease nest success; they recommended June operation to force alligators to lay eggs on high areas. In the long term, improved NPP should improve alligator forage.

\section{Endophytic Fungi}

The beneficial mycorrhizal and foliar fungi living in wetland plants of the Bayou Manchac and Lake Maurepas region have been documented by Kandalepas and others (2010). All 18 plant species studied contained dark septate fungi or mycorrhizae. Recently, endophytes were studied in the roots of baldcypress growing at different distances from the outfall 
pipe of the Hammond assimilation wetland, as well as in natural baldcypress swamps (J. Janowsky, S. Van Bael, and others, Tulane University, unpub. data, 2015). Among sites, root bacterial communities were more abundant and diverse in the assimilation wetland, with Fisher's alpha diversity values more than twice that of natural sites. These results suggest that endophyte community composition is diversified in nutrientaugmented environments. Within the assimilation wetland site, the bacterial to fungal ratio increased with distance from the outfall pipe. Because nutrients decrease with distance from the outfall pipe, this suggests that bacterial and fungal endophytes respond differently to nutrient levels.

\section{Insects}

Forested wetlands in the coastal zone of Louisiana are often affected by insect herbivory during spring months, depending on location and year. Though there are no known consistent populations of tree-killing beetles, borers, or diseases, both baldcypress and water tupelo are defoliated frequently by caterpillars (Effler and others, 2006). For decades, baldcypress was renowned for its lack of serious insect and disease problems (Brown and Montz, 1986). Since the first recorded outbreak of Archips goyerana (baldcypress leafroller; Kruse, 2000) in 1983, however, baldcypress has experienced significant, often repeated, springtime defoliation (Lundberg and others, 2011). Impact caused by baldcypress leafroller defoliation is of two main types: diameter growth reduction in individual trees and dieback of the forest canopy (followed in isolated cases by individual tree mortality). Although all sizes and maturity levels of trees are affected, pole-size trees, trees growing along edges of open water, and understory saplings appear to be the most heavily and frequently defoliated by the immature stages of this insect (Kruse, 2000).

Water tupelo, the other dominant swamp canopy species, has been defoliated regularly by Malacosoma disstria (forest tent caterpillar), with regular outbreaks recorded since 1948 (Blair and Langlinais, 1960). In Louisiana, widespread, complete canopy defoliation by the forest tent caterpillar has occurred over as much as 200,000 hectares during a single season (Goyer and Lenhard, 1988). Often, defoliation of water tupelo and baldcypress coexists, and swamps develop an appearance of winter-like dormancy prior to refoliation in late spring or early summer. Because wetlands often are stressed by both abiotic and biotic factors, determining the precise impact due to insect defoliation is difficult. Nevertheless, a strong negative relation between the degree of defoliation of baldcypress and mean annual growth has been measured (Goyer and Chambers, 1996). Growth reduction caused by defoliation is often exacerbated by duration and depth of flooding and (or) saltwater intrusion (Nachod and Kucera, 1971; Lowery, 1974; Goyer and Chambers, 1996).
Weller (2014) studied insect distribution and abundance in the Hammond assimilation wetland before and during habitat degradation and also following habitat recovery. Differences occurred in insect community composition across time, with the insect community prior to habitat degradation having the highest diversity, the insect community when the wetland reverted to open water being representative of that of a degraded wetland with the lowest diversity, and the community when sampled a few years later being representative of an intermediate insect community with similarities to both the intact and degraded communities, but more similar to the intact. Weller (2014) also found that there was a small but significant difference in insect communities closest to the discharge pipe versus 50 and $100 \mathrm{~m}$ out from the outfall, but no difference between the 50- and 100-m samples. He identified some specific taxa for marshes that could be used as indicators of high-quality habitat (Suphisellus bicolor, a beetle) and low-quality habitat (two species of flies in the family Chironomidae and a species of Hemiptera in the family Corixidae, Palmacorixa buenoi).

\section{Other Monitoring Efforts}

The LPBF's Hydrocoast program (http://saveourlake.org/ lpbf-programs/coastal/hydrocoast-maps/) collects a number of environmentally dynamic datasets in an effort to monitor the condition (salinity component) of the Pontchartrain Basin's estuaries. Wind, rain, tides, and freshwater influx from streams and diversions are variables that cause salinity fluctuation and play a vital role in the health of the basin's estuaries. The Hydrocoast program monitors these variables over a 7-day period and produces bimonthly map products showing the movement of water and salinity across the basin (by using field data, Moderate Resolution Imaging Spectroradiometer [MODIS] satellite imagery, precipitation data, wind data, and permanent monitoring stations in the basin). As a tool, these map products can be used for scientific discussion, for restoration planning between State and Federal agencies, and by the commercial and recreational fishery communities.

\section{Management Plans}

In 2006, "Comprehensive Habitat Management Plan for the Pontchartrain Basin" was released by the LPBF (2006). Many of the restoration projects proposed in this document are also proposed in "Comprehensive Master Plan for a Sustainable Coast” (State of Louisiana, 2012). In addition, The Nature Conservancy, in conjunction with the LPBF, mapped priority conservation areas in the Lake Pontchartrain Estuary zone (McInnis and Rogers, 2006). 
Table 1-1. Scientific and common names of important trees, shrubs, and herbaceous plants of Maurepas Swamp, Louisiana (modified from Effler and others, 2007).

\begin{tabular}{|c|c|}
\hline \multicolumn{2}{|l|}{ Trees and shrubs } \\
\hline Acer rubrum var. drummondii (Hook. \& Arn. ex Nutt.) Sarg. & Swamp red maple \\
\hline Cephalanthus occidentalis L. & Buttonbush \\
\hline Fraxinus pennsylvanica Marsh. & Green ash \\
\hline Morella cerifera (L.) Small & Southern waxmyrtle \\
\hline Nyssa aquatica L. & Water tupelo \\
\hline Nyssa biflora Walter & Swamp tupelo \\
\hline Quercus laurifolia Michx. & Laurel oak \\
\hline Salix nigra Marshall & Black willow \\
\hline Taxodium distichum (L.) Rich & Baldcypress \\
\hline Triadica sebifera (L.) Small & Chinese tallow ${ }^{1}$ \\
\hline \multicolumn{2}{|l|}{ Herbaceous plants } \\
\hline Alternanthera philoxeroides (Mart.) Griseb. & Alligatorweed $^{1}$ \\
\hline Amaranthus australis (A. Gray) J.D. Sauer & Pigweed \\
\hline Aster spp. & Asters \\
\hline Baccharis halimifolia $\mathrm{L}$. & Eastern baccharis \\
\hline Echinochloa walteri (Pursh) A. Heller & Walter's millet \\
\hline Eleocharis spp. & Spikerush \\
\hline Galium tinctorium $\mathrm{L}$. & Stiff marsh bedstraw \\
\hline Hydrocotyle spp. & Hydrocotyle \\
\hline Iris virginica $\mathrm{L}$. & Blue flag \\
\hline Panicum hemitomon Schult. & Maidencane \\
\hline Peltandra virginica (L.) Schott & Green arrow arum \\
\hline Polygonum spp. & Smartweed \\
\hline Pontederia cordata L. & Pickerelweed \\
\hline Sabal minor (Jacq.) Pers. & Dwarf palmetto \\
\hline Sagittaria lancifolia L. & Bulltongue \\
\hline Vigna luteola (Jacq.) Benth. & Deer pea \\
\hline
\end{tabular}

${ }^{1}$ Introduced invasive plant. 
Table 1-2. Salinity, forest condition, and basal area within coastal swamp forests of Louisiana.

[yr, year; $\mathrm{m}^{2} /$ ha, square meter per hectare; psu, practical salinity unit; SE, standard error of the mean; SW, surface water; PW, pore water; $\mathrm{n} / \mathrm{a}$, not available]

\begin{tabular}{|c|c|c|c|c|c|c|c|}
\hline Location & Habitat & $\begin{array}{l}\text { Sample } \\
\text { type }^{1}\end{array}$ & $\begin{array}{l}\text { Record } \\
\text { length, yr }\end{array}$ & $\begin{array}{l}\text { Basal } \\
\text { area, } \\
\mathrm{m}^{2} / \mathrm{ha}\end{array}$ & $\begin{array}{l}\text { Salinity, } \\
\text { psu }\end{array}$ & $\begin{array}{l}\text { Salinity, } \\
\text { SE }\end{array}$ & Source $^{2}$ \\
\hline East of Gibson & Alluvial & SW & 6 & 70.8 & 0.27 & 0.00 & CRMS0414 \\
\hline $\begin{array}{c}\text { Jean Lafitte National } \\
\text { Historical Park and } \\
\text { Preserve (NHPP) }\end{array}$ & Impounded, freshwater & PW & 5 & 70.6 & 0.42 & 0.06 & $\begin{array}{l}\text { Krauss and } \\
\text { others } \\
(2009)\end{array}$ \\
\hline Southern Maurepas & Microtidal, low salinity exposure & SW & 6 & 68.5 & 0.38 & 0.00 & CRMS5373 \\
\hline Jean Lafitte NHPP & Freshwater (limited description) & SW & 5 & 62.9 & 0.12 & 0.00 & CRMS0234 \\
\hline Southern Maurepas & Somewhat impounded & SW & 5 & 61.7 & 0.34 & 0.00 & CRMS0039 \\
\hline Southern Maurepas & Impounded but healthy & SW & 5 & 61.1 & 0.14 & 0.00 & CRMS0008 \\
\hline Maurepas (Hope Canal) & Freshwater & PW & 4 & 57.1 & 0.81 & 0.10 & $\begin{array}{l}\text { Hoeppner } \\
\text { and others } \\
(2008)\end{array}$ \\
\hline Southern Maurepas & Semi-impounded but healthy & SW & 6 & 57.1 & 0.27 & 0.00 & CRMS0065 \\
\hline North of Morgan City & Alluvial & SW & 6 & 56.6 & 0.15 & 0.00 & CRMS0403 \\
\hline Bayou Chevreuil & Freshwater & PW & 5 & 56.2 & 0.57 & 0.05 & $\begin{array}{l}\text { Krauss and } \\
\text { others } \\
(2009)\end{array}$ \\
\hline $\begin{array}{l}\text { Bayou Teche National } \\
\text { Wildlife Refuge (NWR) }\end{array}$ & Impounded, freshwater & PW & 5 & 53.4 & 0.42 & 0.02 & $\begin{array}{l}\text { Krauss and } \\
\text { others } \\
(2009)\end{array}$ \\
\hline Pearl River & $\begin{array}{l}\text { Alluvial, microtidal, episodic salinity } \\
\text { events }\end{array}$ & SW & 6 & 52.1 & 1.41 & 0.03 & CRMS6090 \\
\hline Northern Maurepas & Microtidal, low salinity exposure & SW & 6 & 51.7 & 0.39 & 0.01 & CRMS0046 \\
\hline South of Gibson & Freshwater (limited description) & SW & 5 & 49.6 & 0.21 & 0.00 & CRMS5035 \\
\hline South of Franklin & Semi-impounded, episodic salinity events & SW & 5 & 47.5 & 0.27 & 0.00 & CRMS5992 \\
\hline Southern Maurepas & Impounded but healthy & SW & 6 & 47.4 & 0.42 & 0.00 & CRMS0063 \\
\hline Northern Maurepas & Microtidal, low salinity exposure & SW & 5 & 47.2 & 0.20 & 0.00 & CRMS5452 \\
\hline Western Maurepas & $\begin{array}{l}\text { Microtidal, episodic salinity events, higher } \\
\text { elevation }\end{array}$ & SW & 6 & 46.3 & 0.49 & 0.01 & CRMS0061 \\
\hline Southern Maurepas & Borders uplands, microtidal & SW & 7 & 45.5 & 0.26 & 0.00 & CRMS0059 \\
\hline East of Pierre Part & Alluvial & SW & 6 & 44.5 & 0.16 & 0.00 & CRMS5536 \\
\hline Western Maurepas & Semi-impounded & SW & 5 & 42.7 & 0.32 & 0.00 & CRMS5167 \\
\hline Pearl River & $\begin{array}{l}\text { Alluvial, microtidal, episodic salinity } \\
\text { events }\end{array}$ & SW & 6 & 40.1 & 1.44 & 0.03 & CRMS6088 \\
\hline Southern Maurepas & Semi-impounded, episodic salinity events & SW & 6 & 39.6 & 0.77 & 0.00 & CRMS0047 \\
\hline Western Maurepas & Microtidal, low salinity exposure & SW & 6 & 38.3 & 0.57 & 0.00 & CRMS0097 \\
\hline North of Pierre Part & Alluvial & SW & 5 & 37.9 & 0.16 & 0.00 & CRMS0324 \\
\hline Jean Lafitte NHPP & Microtidal, degraded & PW & 5 & 36.9 & 2.01 & 0.06 & $\begin{array}{l}\text { Krauss and } \\
\text { others } \\
(2009)\end{array}$ \\
\hline West of Convent & Freshwater (limited description) & SW & 5 & 36.4 & 0.56 & 0.00 & CRMS5116 \\
\hline
\end{tabular}


Table 1-2. Salinity, forest condition, and basal area within coastal swamp forests of Louisiana.—Continued

[yr, year; $\mathrm{m}^{2} /$ ha, square meter per hectare; psu, practical salinity unit; SE, standard error of the mean; SW, surface water; PW, pore water; $\mathrm{n} / \mathrm{a}$, not available]

\begin{tabular}{|c|c|c|c|c|c|c|c|}
\hline Location & Habitat & $\begin{array}{l}\text { Sample } \\
\text { type }^{1}\end{array}$ & $\begin{array}{l}\text { Record } \\
\text { length, yr }\end{array}$ & $\begin{array}{l}\text { Basal } \\
\text { area, } \\
\mathrm{m}^{2} / \mathrm{ha}\end{array}$ & $\begin{array}{l}\text { Salinity, } \\
\text { psu }\end{array}$ & $\begin{array}{l}\text { Salinity, } \\
\text { SE }\end{array}$ & Source $^{2}$ \\
\hline Fleming Property, Lafitte & Microtidal, degraded & PW & 5 & 36.1 & 2.13 & 0.16 & $\begin{array}{c}\text { Krauss and } \\
\text { others } \\
(2009)\end{array}$ \\
\hline Maurepas (Interior West) & Semidegraded & PW & 4 & 31.7 & 0.98 & 0.06 & $\begin{array}{l}\text { Hoeppner } \\
\text { and others } \\
(2008)\end{array}$ \\
\hline Southern Maurepas & Microtidal, episodic salinity events & SW & 6 & 30.0 & 1.62 & 0.01 & CRMS0056 \\
\hline Southern Maurepas & Semi-impounded, episodic salinity events & SW & 7 & 29.3 & 0.48 & 0.00 & CRMS0089 \\
\hline South of Morgan City & Freshwater (limited description) & SW & 5 & 28.9 & 0.19 & 0.00 & CRMS4938 \\
\hline Western Maurepas & Microtidal, episodic salinity events & SW & 6 & 28.2 & 0.55 & 0.00 & CRMS0038 \\
\hline Mandalay NWR & Impounded, slightly degraded & PW & 5 & 26.9 & 1.62 & 0.15 & $\begin{array}{c}\text { Krauss and } \\
\text { others } \\
(2009)\end{array}$ \\
\hline Pearl River & $\begin{array}{l}\text { Alluvial, microtidal, episodic salinity } \\
\text { events }\end{array}$ & SW & 6 & 24.8 & 1.51 & 0.03 & CRMS0086 \\
\hline Southern Maurepas & Microtidal, episodic salinity events & SW & 6 & 24.2 & 0.60 & 0.00 & CRMS5414 \\
\hline Western Maurepas & Microtidal, episodic salinity events & SW & 6 & 23.8 & 0.63 & 0.01 & CRMS5255 \\
\hline South of Jeanerette & Semi-impounded, episodic salinity events & SW & 5 & 22.7 & 1.07 & 0.01 & CRMS0547 \\
\hline South of Calumet & Freshwater (limited description) & SW & 5 & 20.6 & 0.20 & 0.00 & CRMS6008 \\
\hline Jean Lafitte NHPP & Freshwater (limited description) & SW & 2 & 18.3 & 0.35 & 0.00 & CRMS0185 \\
\hline Southern Maurepas & Semi-impounded, episodic salinity events & SW & 8 & 16.6 & 0.86 & 0.01 & CRMS0058 \\
\hline South of Morgan City & Freshwater (limited description) & SW & 6 & 15.0 & 0.19 & 0.00 & CRMS4900 \\
\hline South of Baldwin & Semi-impounded, episodic salinity events & SW & 7 & 11.2 & 0.57 & 0.00 & CRMS0513 \\
\hline Western Maurepas & Microtidal, episodic salinity events & SW & 6 & 9.9 & 0.56 & 0.01 & CRMS5845 \\
\hline Maurepas (Lake) & Microtidal, degraded & PW & 4 & 8.0 & 2.16 & 0.09 & $\begin{array}{l}\text { Hoeppner } \\
\text { and others } \\
(2008)\end{array}$ \\
\hline Northern Maurepas & $\begin{array}{l}\text { Alluvial, microtidal, episodic salinity } \\
\text { events }\end{array}$ & SW & 4 & 5.5 & 0.50 & 0.00 & CRMS5267 \\
\hline Northern Pontchartrain & Microtidal, chronic salinity events & SW & 6 & 2.5 & 1.24 & 0.02 & CRMS0103 \\
\hline Northern Pontchartrain & Microtidal, chronic salinity events & SW & 6 & 0.5 & 1.79 & 0.01 & CRMS6209 \\
\hline Dulac (Falgout Canal) & Microtidal, degraded & PW & 1 & $\mathrm{n} / \mathrm{a}$ & 3.73 & 1.52 & Allen (1994) \\
\hline $\begin{array}{l}\text { St. Bernard (E.J. Gore } \\
\text { Station) }\end{array}$ & Microtidal, degraded & PW & 1 & $\mathrm{n} / \mathrm{a}$ & 2.30 & 0.43 & Allen (1994) \\
\hline $\begin{array}{l}\text { Venice (along } \\
\text { Mississippi River) }\end{array}$ & Semidegraded & PW & 1 & $\mathrm{n} / \mathrm{a}$ & 1.18 & 0.65 & Allen (1994) \\
\hline
\end{tabular}

${ }^{1}$ Data acquired from pore water (PW) or surface water (SW) samples.

${ }^{2}$ Source of Coastwide Reference Monitoring System (CRMS) station data, http://cims.coastal.la.gov/. 


\section{References Cited}

Abadie, S.W., and Poirrier, M.A., 2001, Rangia clams as indicators of hypoxia in Lake Pontchartrain, in Penland, S., Bealle, A. and Waters, J., eds., Environmental atlas of the Lake Pontchartrain Basin: New Orleans, Lake Pontchartrain Basin Foundation.

Amstutz, D.E., 1964, Analysis of the salinity regime of the Mississippi River-Gulf Outlet Channel: College Station, Texas A\&M Research Foundation, projects 286-1 and 299, reference $64-21 \mathrm{~T}$.

Beville, S.L., 2002, The efficacy of a small-scale freshwater diversion for restoration of a swamp in southeastern Louisiana: Hammond, Southeastern Louisiana University, M.S. thesis.

Blair, R.M., and Langlinais, M.J., 1960, Nutria and swamp rabbits damage baldcypress seedlings: Journal of Forestry, v. 58, p. $388-389$.

Boshart, W.M., 1997, The conservation and restoration of a baldcyress swamp - An investigation of macronutrients, competition, and induced vegetation dynamics as related to nutria herbivory: Hammond, Southeastern Louisiana University, M.S. thesis.

Brown, C.A., and Montz, G.N., 1986, Baldcypress-The tree unique, the wood eternal: Baton Rouge, Louisiana, Claitor's Publishing Division.

Cahoon, D.R., 2015, Estimating relative sea-level rise and submergence potential as a coastal wetland: Estuaries and Coasts, v. 38, p. 1077-1084.

Cahoon, D.R., Day, J.W., Jr., and Reed, D.J., 1999, The influence of surface and shallow subsurface soil processes on wetland elevation-A synthesis: Current Topics in Wetland Biogeochemistry, v. 3, p. 72-88.

Callaway, J.C., Cahoon, D.R., and Lynch, J.C., 2013, The surface elevation table-marker horizon method for measuring wetland accretion and elevation dynamics, in DeLaune, R.D., Reddy, K.R., Richardson, C.J., and Megonigal, J.P., eds., Methods in biogeochemistry of wetlands: Madison, Wisconsin, Soil Science Society of America Book Series 10, p. 901-917.

Chambers, J.L., Conner, W.H., Day, J.W., Jr, Faulkner, S.P., Gardiner, E.S., Hughes, M.S., Keim, R.F., King, S.L., McLeod, K.W., Miller, C.A., Nyman, J.A., and Shaffer, G.P., 2005, Conservation, protection and utilization of Louisiana's coastal wetland forests: Baton Rouge, Final report to the Governor of Louisiana from the Coastal Wetland Forest Conservation and Use Science Working Group, 102 p.
Cho, H.J., and Poirrier, M.A., 2005, A model to estimate potential SAV (submersed aquatic vegetation) habitat based on studies in Lake Pontchartrain: Restoration Ecology, v. 13 , p. 623-629.

Conner, W.H., Duberstein, J.A., Day J.W., Jr., and Hutchinson, S., 2014, Impacts of changing hydrology and hurricanes on forest structure and growth along a flooding/elevation gradient in a south Louisiana forested wetland from 1986 to 2009: Wetlands, v. 34, p. 803-814.

Conner, W.H., Toliver, J.R., and Sklar, F.H., 1986, Natural regeneration of baldcypress (Taxodium distichum (L.) Rich.) in a Louisiana swamp: Forest Ecology and Management, v. 14 , p. $305-317$.

Darnell, R.M., 1958, Food habitats of fishes and larger invertebrates of Lake Pontchartrain, Louisiana, an estuarine community: University of Texas, Publications Institute of Marine Science, v. 5, p. 353-416.

Day, J.W., Jr., Ko, J.-Y., Rybczyk, J., Sabins, D., Bean, R., Berthelot, G., Brantkey, C., Cardoch, L., Conner, W., Day, J.N., Englande, A.J., Feagley, S., Hyfield, E., Lane, R., Lindsey, J., Mistich, J., Reyes, E., and Twilley, R., 2004, The use of wetlands in the Mississippi Delta for wastewater assimilation-A review: Journal of Ocean and Coastal Management, v. 47, p. 671-691.

Effler, R.S., Goyer, R.A., and Lenhard, G.J., 2006, Baldcypress and water tupelo responses to insect defoliation and nutrient augmentation in Maurepas Swamp, Louisiana: Forest Ecology and Management, v. 236, p. 295-304.

Effler, R.S., Shaffer, G.P., Hoeppner, S.S., and Goyer, R.A., 2007, Ecology of the Maurepas Swamp —Effects of salinity, nutrients, and insect defoliation, in Conner, W.H., Doyle, T.W., and Krauss, K.W., eds., Ecology of tidal freshwater forested wetlands of the southeastern United States: New York, Springer, p. 349-384.

El-Sayed, S.Z., 1961, Hydrological and biological studies of the Mississippi River-Gulf Outlet project: College Station, Texas A\&M Research Foundation, project 236, reference $61-20 \mathrm{~F}$.

Folse, T.M., Sharp, L.A., West, J.L., Hymel, M.K., Troutman, J.P., McGinnis, T.E., Weifenbach, D., Boshart, W.M., Rodrigue, L.B., Richardi, D.C., Wood, W.B., and Miller, C.M., 2014, A Standard operating procedures manual for the Coast-Wide Reference Monitoring System-WetlandsMethods for site establishment, data collection, and quality assurance/quality control: Baton Rouge, Louisiana Coastal Protection and Restoration Authority, Office of Coastal Protection and Restoration, 228 p., accessed April 4, 2017, at http://cims.coastal.la.gov.

Fontenot, C.L., Jr., 2011, Hyla cinerea (green treefrog) winter aggregation: Herpetological Review, v. 42, p. 84-85. 
Fox, D.M., 2006, Effects of insectivorous birds on tree growth in the Maurepas Swamp: Baton Rouge, Louisiana State University, M.S. thesis.

Fox, D.M., Stouffer, P.C., Rutherford, D.A., Kelso, W.E., LaPeyre, M., and Bambarger, R., 2007, Impacts of a freshwater diversion on wildlife and fishes in the Maurepas Swamp: U.S. Environmental Protection Agency, no. DW-1495045601-1, EPA Region 6, 152 p.

Francis, J.C., Poirrier, M.A, Barbe, D.E., Wijesundera, V., and Mulino, M.M., 1994, Historic trends in the Secchi disk transparency of Lake Pontchartrain: Gulf Research Reports, v. 9 , p. $1-16$.

Goyer, R.A., and Chambers, J.L., 1996, Evolution of insect defoliation in baldcypress and its relationship to flooding: National Biological Service, Biological Sciences Report 8.

Goyer, R.A., and Lenhard, C.G., 1988, A new insect pest threatens baldcypress: Louisiana Agriculture, v. $31,16-17,21$.

Greene, M.C., 1994, The interacting effects of autogenic and allogenic agents on selected swamp and freshmarsh vegetation: Hammond, Southeastern Louisiana University, M.S. thesis.

Hall, B.D., Aiken, G.R., Krabbenhoft, D.P., MarvinDiPasquale, M., and Swazenski, C.M., 2008, Wetlands as principal zones of methylmercury production in southern Louisiana and the Gulf of Mexico region: Environmental Pollution, v. 154, p. 124-134.

Harris, J.O., Zwank, P.J., and Dugoni, J.A., 1987, Habitat selection and behavior of nesting bald eagles in Louisiana: Journal of Raptor Research, v. 21, p. 27-31.

Hastings, R.W., Turner, D.A., and Thomas, R.G., 1987, The fish fauna of Lake Maurepas, an oligohaline part of the Lake Pontchartrain Estuary: Northeast Gulf Science, v. 9, p. 89-98.

Henkel, T.K., Hillmann, E.R., Butcher, K., Baker, D.B., and Lopez, J.A., 2017, Potential occurrence of natural swamp regeneration of the Maurepas Land Bridge, Southeast Louisiana: Lake Pontchartrain Basin Foundation, 24 p.

Junot, J.A., Poirrier, M.A., and Soniat, T.M., 1983, Effects of saltwater intrusion from the Inner Harbor Navigation Canal on the benthos of Lake Pontchartrain, Louisiana: Gulf Research Reports, v. 7, p. 247-254.

Kaller, M.J., 2003, Transitions between oligohaline and mesohaline marshes - Effects of herbivory, nutrient addition, and disturbance: New Orleans, University of New Orleans, M.S. thesis.
Kandalepas, D., Stevens, K.J., Shaffer, G.P., and Platt, W.J., 2010, How abundant are root-colonizing fungi in southeastern Louisiana's degraded marshes?: Wetlands, v. 30, p. 189-197.

Kruse, J.J., 2000, Archips goyerana, N. Sp. (Lepidoptera: Tortricidae) an important pest of baldcypress (Taxodiaceae) in Louisiana and Mississippi: Proceedings of the Entomological Society of Washington, v. 102, p. 741-746.

Lake Pontchartrain Basin Foundation (LPBF), 2006, Comprehensive habitat management plan for the Pontchartrain Basin: Metairie, Lake Pontchartrain Basin Foundation.

Lane, R.R., Mashriqui, H.S., Kemp, G.P., and others, 2003, Potential nitrate removal from a river diversion into a Mississippi Delta forested wetland: Ecological Engineering, v. 20, p. $237-249$.

Lowery, G.H., Jr., 1974, Mammals of Louisiana and its adjacent waters: Baton Rouge, Louisiana State University Press, $565 \mathrm{p}$.

Lundberg, C.J., 2008, using secondarily treated sewage effluent to restore the baldcypress-water tupelo swamps of the Lake Pontchartrain Basin-A demonstration study: Hammond, Southeastern Louisiana University, M.S. thesis, 85 p.

Lundberg, C.J., Shaffer, G.P., Wood, W.B., and Day, J.W., Jr., 2011, Growth rates of baldcypress (Taxodium distichum) seedlings in a treated effluent assimilation marsh: Ecological Engineering, v. 37, p. 549-553.

McCardle, L.D., and Fontenot, C.L., Jr., 2016, The influence of thermal biology on road mortality risk in snakes: Journal of Thermal Biology, v. 56, p. 9-49.

McCardle, L.D., Haase, A., and Fontenot, C.L., Jr., 2014, Nerodia clarkii (gulf salt marsh snake) distribution: Herpetological Review, v. 45, p. 95.

McCorquodale, J.A., and Georgiou, I., 2002, Hydrodynamic modeling of salinity intrusion into Lake Pontchartrain, basics of the Basin Research Symposium: Proceedings, May 2002, University of New Orleans [abstract].

McInnis, N., and Rogers, B., 2006, Priority conservation areas in the Lake Pontchartrain Estuary zone: The Nature Conservancy and Lake Pontchartrain Basin Foundation.

McKee, K.L., Cahoon, D.R., and Feller, I.C., 2007, Caribbean mangroves adjust to rising sea level through biotic controls on change in soil elevation: Global Ecology and Biogeography, v. 16, p. 545-556.

Millican, T., Turner, D., and Thomas, G., 1984, Checklist of fishes of Lake Maurepas: Proceedings of the Louisiana Academy of Sciences, v. 47, p. 30-33. 
Myers, R.S., Shaffer, G.P., and Llewellyn, D.W., 1995, Baldcypress (Taxodium distichum (L.) Rich.) restoration in southeast Louisiana-The relative effects of herbivory, flooding, competition, and macronutrients: Wetlands, v. 15, p. 141-148.

Nachod, L.H., and Kucera, D.R., 1971, Observations of the forest tent caterpillar in south Louisiana: Woodworth, Louisiana Office of Forestry, Insect and Disease Report.

O'Connell, M., Cashner, R., and Schieble, C.S., 2004, Fish assemblage stability over 50 years in the Lake Pontchartrain Estuary - Comparisons among habitats using canonical correspondence analysis: Estuaries, v. 27, p. 807-817.

Poirrier, M.A., 1978, Studies of salinity stratification in southern Lake Pontchartrain near the Inner Harbor Navigation Canal: Proceeding of the Louisiana Academy of Sciences, v. 41, p. 26-35.

Poirrier, M.A., Abadie, S.W., and Franze, C.D., 2001, Rangia clams as indicators of hypoxia in Lake Pontchartrain, in Proceedings Basics of the Basin Research Symposium: New Orleans, University of New Orleans, p. 62.

Poirrier, M.A., Soniat, T.M., King, Y., and Smith, L., 1984, An evaluation of the southern Lake Pontchartrain benthos community: New Orleans, Louisiana Department of Environmental Quality, Office of Water Resources Water Pollution Control Division, 64003-84-05.

Poirrier, M.A., and Spalding, E.A., 2004, The importance of Rangia cuneata clam restoration to the holistic rehabilitation of the Lake Pontchartrain Estuary: New Orleans, Lake Pontchartrain Basin Foundation.

Poirrier, M.A., Spalding, E.A., and Franze, C.D., 2009, Lessons learned from a decade of assessment and restoration of benthic invertebrates and submersed aquatic vegetation in Lake Pontchartrain: Journal of Coastal Research, v. SI 54, p. $88-100$.

Powers, S.P., Poirrier, M.A., and Yund, P.O., 1992, Effects of urban runoff on infaunal invertebrates in southern Lake Pontchartrain: Water Environment Federation 65th Annual Conference and Exposition, p. 15-18.

Rounsefell, G.A., 1964, Preconstruction study of the fisheries of the estuarine areas traversed by the Mississippi RiverGulf Outlet Project: Fishery Bulletin, v. 63, p. 373-393.

Rutherford, M., 2015, Analyzing site suitability for baldcypress (Taxodium distichum) regeneration along a hydrologic gradient in south Louisiana swamps: Baton Rouge, Louisiana State University, M.S. thesis.

Schriever, T.A., Ramspott, J., Crother, B.I., and Fontenot, C.L., Jr., 2009, Effects of hurricanes Ivan, Katrina, and Rita on a southeastern Louisiana herpetofauna: Wetlands, v. 29, p. 112-122.
Shaffer, G.P., Day, Jr., J.W., Hunter, R.G., Lane, R.R., Lundberg, C.J., Wood, W.B., Hillmann, E.R., Day, J.N., Strickland, E., and Kandalepas, D., 2015, System response, nutria herbivory, and vegetation recovery of a wetland receiving secondarily-treated effluent in coastal Louisiana: Ecological Engineering, v. 79, p. 120-131.

Shaffer, G.P., Day, Jr., J.W., Kandalepas, D., Wood, W.B., Hunter, R.G., Lane, R.R., and Hillmann, E.R., 2016, Decline of the Maurepas Swamp, Pontchartrain Basin, Louisiana, and approaches to restoration: Water, v. 8, w8030101.

Shaffer, G.P., Day, Jr., J.W., Mack, S., Kemp, G.P., van Heerden, I., Poirrier, M.A., Westphal, K.A., FitzGerald, D., Milanes, A., Morris, C.A., Bea, R., and Penland, P.S., 2009b, The MRGO navigation project - A massive humaninduced environmental, economic, and storm disaster: Journal of Coastal Research, v. SI 54, p. 206-224.

Shaffer, G.P., Perkins, T.E., Hoeppner, S.S., Howell, S., Benard, T.H., and Parsons, A.C., 2003, Ecosystem health of the Maurepas Swamp-Feasibility and projected benefits of a freshwater diversion: Dallas, Texas, U.S. Environmental Protection Agency, Region 6, Final Report, 95 p.

Shaffer, G.P., Wood, W.B., Hoeppner, S.S., Perkins, T.E., Zoller, J., and Kandalepas, D., 2009a, Degradation of baldcypress-water tupelo swamps to marsh and open water in southeastern Louisiana, U.S.A.-An irreversible trajectory: Journal of Coastal Research, v. SI 54, p. 152-165.

Sikora, W.B., and Kjerfve, B., 1985, Factors influencing the salinity regime of Lake Pontchartrain, Louisiana, a shallow coastal lagoon-Analysis of a long-term data set: Estuaries, v. 8 , p. $170-180$.

Sikora, W.B., and Sikora, J.P., 1982, Ecological characterization of the benthic community of Lake Pontchartrain, Louisiana: New Orleans, U.S. Army Corps of Engineers, New Orleans District.

Spalding, E.A., Walker, A.E., and Poirrier, M.A., 2006, Restoration of 100 square miles of shellfish habitat in Lake Pontchartrain: U.S. Environmental Protection Agency, Gulf of Mexico Program, MX974852-03-0.

State of Louisiana, 2012, Louisiana's comprehensive master plan for a sustainable coast: Baton Rouge, State of Louisiana, Coastal Protection and Restoration Authority, 190 p.

Steyer, G.D., Sasser, C.E., Visser, J.M., Swenson, E.M., Nynam, J.A., and Raynie, R.C., 2003, A proposed coastwide reference monitoring system for evaluating wetland restoration trajectories in Louisiana: Environmental Monitoring and Assessment, v. 81, p. 107-117. 
Thomson, D.A., 2000, The influence of hydrological alterations upon wetland hydrodynamics and plant growth on the Manchac Landbridge, southeastern Louisiana, USA: Hammond, Southeastern Louisiana University, M.S. thesis.

Thomson, D.A., Shaffer, G.P., and McCorquodale, J.A., 2002, A potential interaction between sea-level rise and global warming - Implications for coastal stability on the Mississippi River Deltaic Plain: Global Planetary Change, v. 32, p. 49-59.

Weller, M.O., 2014, Analysis of invertebrate diversity dynamics in a wastewater assimilation marsh in southeast Louisiana: Hammond, Southeastern Louisiana University, M.S. thesis.

Wicker, K.M., Castille, G.C., Davis, D.J., Gagliano, S.M., Roberts, D.W., Sabins, D.S., and Weinstein, R.A., 1982, St. Bernard Parish - A study in wetland management: Baton Rouge, Coastal Environment, Inc.

Zoller, J.A., 2004, Seasonal differences in bird communities of a Louisiana swamp and manipulation of the breeding density of prothonotary warblers: Hammond, Southeastern Louisiana University, M.S. thesis. 



\section{曾}

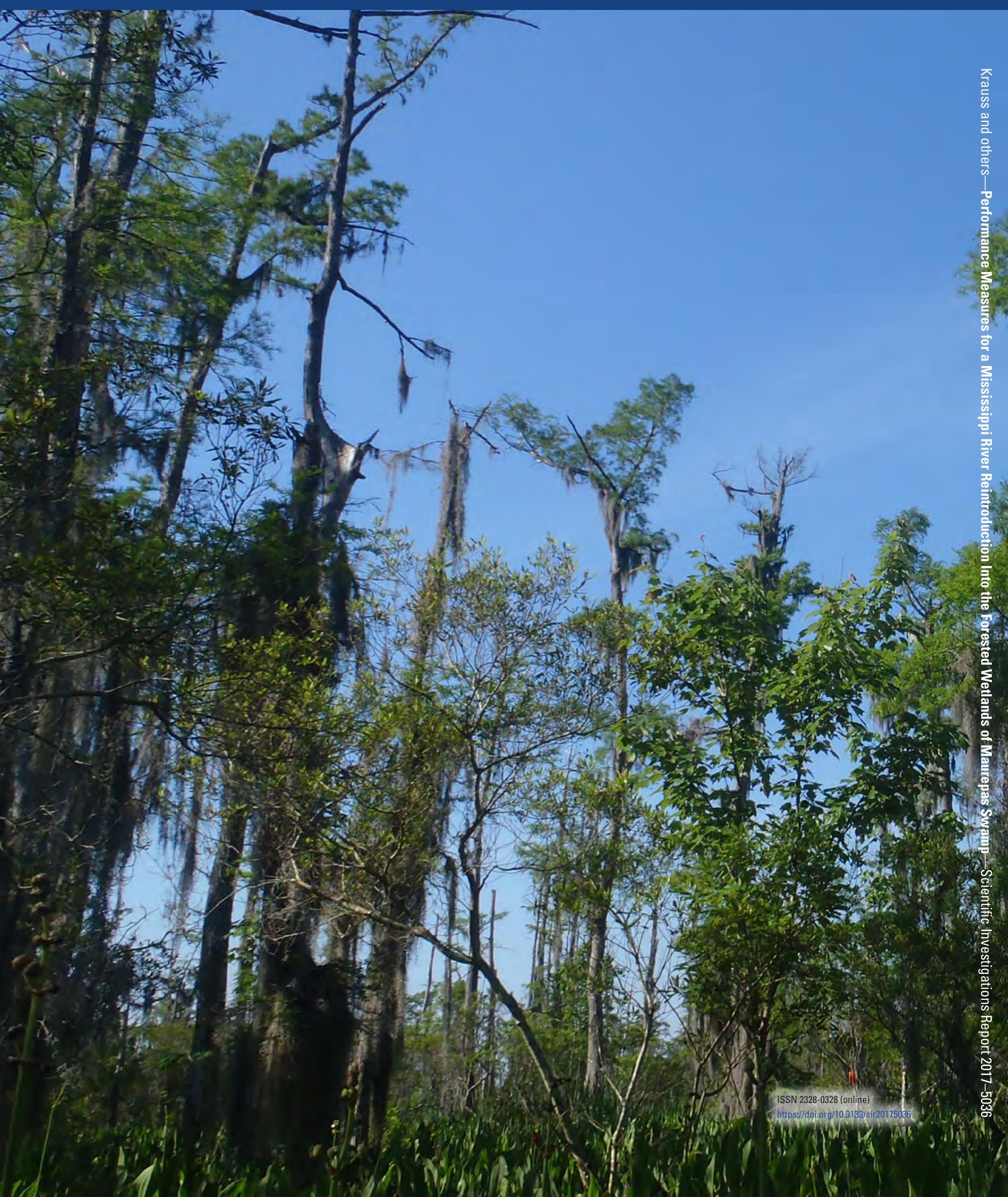

